\title{
Three Essays in International Economics
}

\author{
by
}

\section{Afshan A. Dar-Brodeur}

\author{
A Thesis submitted to \\ the Faculty of Graduate Studies and Research \\ in partial fulfilment of \\ the requirements for the degree of \\ Doctor of Philosophy \\ in \\ Economics \\ Carleton University \\ Ottawa, Ontario, Canada \\ May 2013
}

Copyright (C)

2013 - Afshan A. Dar-Brodeur 
Library and Archives

Canada

Published Heritage

Branch

395 Wellington Street

Ottawa ON K1A ON4

Canada
Bibliothèque et

Archives Canada

Direction du

Patrimoine de l'édition

395 , rue Wellington

Ottawa ON K1A ON4

Canada
Your file Votre référence

ISBN: $978-0-494-94530-8$

Our file Notre référence

ISBN: $978-0-494-94530-8$
NOTICE:

The author has granted a nonexclusive license allowing Library and Archives Canada to reproduce, publish, archive, preserve, conserve, communicate to the public by telecommunication or on the Internet, loan, distrbute and sell theses worldwide, for commercial or noncommercial purposes, in microform, paper, electronic and/or any other formats.

The author retains copyright ownership and moral rights in this thesis. Neither the thesis nor substantial extracts from it may be printed or otherwise reproduced without the author's permission.
AVIS:

L'auteur a accordé une licence non exclusive permettant à la Bibliothèque et Archives Canada de reproduire, publier, archiver, sauvegarder, conserver, transmettre au public par télécommunication ou par l'Internet, prêter, distribuer et vendre des thèses partout dans le monde, à des fins commerciales ou autres, sur support microforme, papier, électronique et/ou autres formats.

L'auteur conserve la propriété du droit d'auteur et des droits moraux qui protege cette thèse. $\mathrm{Ni}$ la thèse ni des extraits substantiels de celle-ci ne doivent être imprimés ou autrement reproduits sans son autorisation.
In compliance with the Canadian Privacy Act some supporting forms may have been removed from this thesis.

While these forms may be included in the document page count, their removal does not represent any loss of content from the thesis.
Conformément à la loi canadienne sur la protection de la vie privée, quelques formulaires secondaires ont été enlevés de cette thèse.

Bien que ces formulaires aient inclus dans la pagination, il n'y aura aucun contenu manquant. 


\section{Abstract}

This thesis is comprised of three essays on the economic impacts of globally integrated markets. The first uses a panel of 72 developing and transition economies to empirically examine the impact of exchange rate volatility on exports. This is a question of significant policy relevance in such countries, since most have shifted dramatically from a policy of inward-orientation (and import-substitution) towards one of export promotion. Using three measures of exchange rate volatility, I address the potential endogeneity of volatility and account for the dynamic nature of exports with Difference and System GMM estimation. Results point to a small yet negative impact of volatility on exports.

The second area of focus is the impact of trade on labour standards, reflecting real-world concerns of a "race-to-the-bottom" (RTB) in labour standards that could arise if countries cut domestic regulations to improve their competitive advantage on international markets. Brander and Spencer's (1985 JIE) international duopoly model of trade is adapted to theoretically examine whether strategic trade considerations lead to a RTB in minimum wages, where these wages are set endogenously to constrain the monopsony power of firms. Analysis suggests that strategic trade considerations do not lead to RTB in minimum wages - governments set wages above the efficient level when they are allowed to use labour subsidies. Prohibiting labour subsidies leads to the efficient wage in equilibrium.

Lastly, the impact of trade on labour standards is examined in the context of legal origins, incorporating newer research suggesting that the legal tradition of a country shapes its approach to regulation. Adapting legal origin theory to the trade and labour standards literature, a new dataset on employment protection covering 90 countries is used to estimate the impact of trade openness on two measures of labour 
standards based on advance notice periods employers are required to give employees upon dismissal. Results suggest that differences in legal origins seem to matter most for economies that are the least open. As trade openness increases, differences due to legal origin wane in relative importance, with countries showing a tendency to move to similar levels of stringency of notice period regulation. 


\section{Acknowledgments}

They say it takes a village to raise a child - I believe the same can be said for finishing a doctorate. This thesis would not have been possible without the support and encouragement of many.

First, I thank my co-supervisors, Professors Zhiqi Chen and Vivek Dehejia, for their continued guidance in this process. I am grateful to the members of my thesis committee who have provided helpful comments and support along the way - Professors Marcel Voia, Hashmat Khan, and Yiagadeesen Samy from Carleton University, and Professor Fernanda Estevan from the University of Ottawa. I also wish to thank other faculty and staff from the department, including Professor Mariko Klasing for helpful discussions in developing my last thesis chapter, Marge Brooks for her continuous encouragement, and my fellow classmates. I am thankful for my external advisor, Professor Bruno Larue from the University of Laval, who gave very helpful comments and has no doubt made this thesis stronger.

I also would like to express my gratitude to the department's $\mathrm{PhD}$ program supervisor, Professor Lynda Khalaf, for her continued support inside and outside of my academic life. She has mentored me throughout this long and arduous process, and I am grateful that I can also call her a friend.

I would have never completed my thesis without the support of my family. I thank my parents, Atul Dar and Najma Sharif, my sister, Sindura Dar, and my husband, Mathieu Brodeur. The depth of my gratitude for them is impossible to put in words. They provided infallible support throughout this long and often challenging process, and have been my biggest cheerleaders at every point along the way. 


\section{Table of Contents}

$\begin{array}{ll}\text { Abstract } & \text { ii }\end{array}$

Acknowledgments $\quad$ iv

Table of Contents $\quad$ v

List of Tables viii

List of Figures $\quad$ ix

1 Introduction 1

2 On the Impact of Exchange Rate Volatility and Exports: A Panel Data Approach $\quad 4$

2.1 Introduction ....................... 4

2.2 Literature Review . . . . . . . . . . . . . . . 7

2.2.1 Theoretical Work .................. 7

2.2 .2 Empirical Work .................. 11

2.3 The Model, Data and Methodology . . . . . . . . . . 18

2.3.1 The Empirical Model . . . . . . . . . . . . . . 18

2.3.2 The Data and Measurement . . . . . . . . . . . . . 21

2.3.3 Estimation Considerations and Methodology . . . . . . . . 28

2.4 Empirical Results . . . . . . . . . . . . . . . 35

2.4.1 Panel Unit Root and Cointegration Tests . . . . . . . . . . 35

2.4 .2 Regression Results . . . . . . . . . . . . . . 38

2.4 .3 System GMM $\ldots \ldots . \ldots . \ldots . \ldots 42$ 
2.5 Extension: Low Income Countries . . . . . . . . . . . . 44

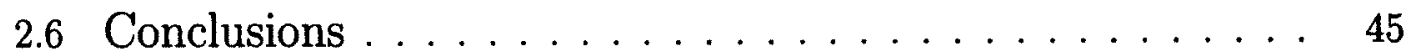

References . . . . . . . . . . . . . . . . 46

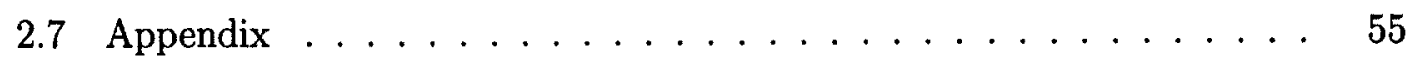

3 Trade and Labour Standards: Will There Be a Race to the Bottom? 63

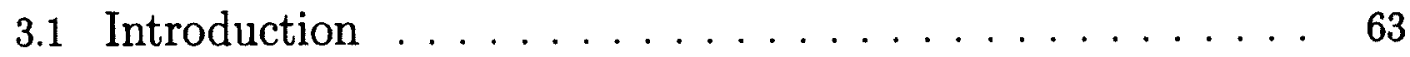

3.2 The Model . . . . . . . . . . . . . . . . . 71

3.2 .1 Benchmark Model . . . . . . . . . . . . . . . 73

3.2 .2 Strategic Interaction $\ldots \ldots \ldots \ldots \ldots \ldots \ldots$

3.2.3 Strategic Interaction and Minimum Wages . . . . . . . . . 80

3.3 Conclusions . . . . . . . . . . . . . . . . . . . . . 91

References . . . . . . . . . . . . . . . . 93

4 Employment Protection Legislation, Trade, and Legal Origins: An $\begin{array}{ll}\text { Empirical Analysis } & 96\end{array}$

4.1 Introduction $\ldots \ldots \ldots \ldots \ldots \ldots \ldots \ldots$

4.2 Literature Review . . . . . . . . . . . . . . . . . . . 99

4.2.1 Trade and Labour Standards . . . . . . . . . . . . . . . 99

4.2.2 Legal Origins and Labour Regulation . . . . . . . . . . . 104

4.3 The Model, Data and Methodology . . . . . . . . . . . 107

4.3.1 The Empirical Model . . . . . . . . . . . . . . . . . . 107

4.3.2 Data and Measurement . . . . . . . . . . . . . . . . 109

4.3.3 Estimation Methodology . . . . . . . . . . . . . . 113

4.4 Results . . . . . . . . . . . . . . . . . . . . 116

4.4 .1 Tobit Regression Results . . . . . . . . . . . . . 117

4.4 .2 Ordered Probit Results . . . . . . . . . . . . . . . 121

4.5 Extension . . . . . . . . . . . . . . . . . . 129 
4.6 Conclusions . . . . . . . . . . . . . . . . . . . . 131

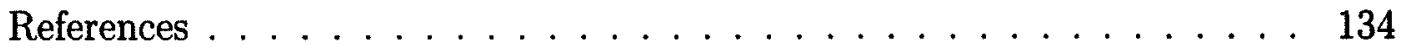

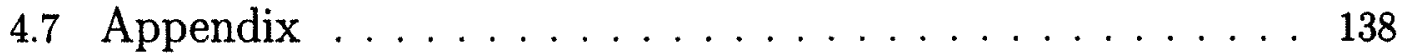

5 Conclusion $\quad 159$ 


\section{List of Tables}

2.1 List of Countries . . . . . . . . . . . . . . . 55

2.2 Real Effective Exchange Rate Volatility by Exchange Rate Regime . . 56

2.3 Summary Statistics, $1991-2008 \ldots \ldots \ldots \ldots \ldots$

2.4 Panel Unit Root Tests . . . . . . . . . . . . . . . 57

2.5 Panel Cointegration Tests $\ldots \ldots \ldots \ldots \ldots$

2.6 Individual Dickey Fuller Tests $\ldots \ldots \ldots \ldots \ldots$

2.7 Fixed Effects and Random Effects with AR(1) Errors, 1991-2008 . . . 59

2.8 Coefficient Estimates: Difference GMM, 1991-2008 . . . . . . . . . . 60

2.9 Coefficient Estimates: System GMM, 1991-2008 _ . . . . . . . . 61

2.10 Difference and System GMM, Low Income Countries, 1991-2008 _. . 62

4.1 Sample of Countries . . . . . . . . . . . . . . . . 138

4.2 Countries by Legal Origin . . . . . . . . . . . . . . . . 139

4.3 Summary Statistics on Notice Periods . . . . . . . . . . . . . . 140

4.4 Notice Periods by Legal Origin . . . . . . . . . . . . . . 141

4.5 Tobit Regressions I-A . . . . . . . . . . . . . . . . . . . . 142

4.6 Tobit Regressions II-A . . . . . . . . . . . . . . . . 143

4.7 Tobit Regressions I-B, Marginal Effects . . . . . . . . . . . . . 144

4.8 Tobit Regressions II-B, Marginal Effects . . . . . . . . . . . 145

4.9 Ordered Probit Regressions I . . . . . . . . . . . . . . . . . 146

4.10 Ordered Probit Regressions II . . . . . . . . . . . . . . . 147

4.11 Predicted Probabilities by Legal Origin I . . . . . . . . . . . 148

4.12 Predicted Probabilities by Legal Origin II . . . . . . . . . . 149 


\section{List of Figures}

3.1 Monopsonistic Labour Market . . . . . . . . . . . . . . . . 81

3.2 Home Labour Market . . . . . . . . . . . . . . . . . . . . 82

4.1 Predicted Probabilities by Trade Share, Notice Periods After Nine Months of Service, $2005 \ldots \ldots \ldots \ldots$

4.2 Predicted Probabilities by Trade Share, Notice Periods After Four Years of Service, $2005 \ldots \ldots \ldots \ldots \ldots \ldots$

4.3 Predicted Probabilities by Trade Share, Notice Periods After 20 Years of Service, $2005 \ldots \ldots \ldots \ldots \ldots \ldots$

4.4 Predicted Probabilities by Trade Share, Notice Periods After Nine Months of Service, $2005 \ldots \ldots \ldots \ldots$

4.5 Predicted Probabilities by Trade Share, Notice Periods After Four Years of Service, $2005 \ldots \ldots \ldots \ldots$. . . . . . . . . 154

4.6 Predicted Probabilities by Trade Share, Notice Periods After 20 Years of Service, $2005 \ldots \ldots \ldots \ldots \ldots \ldots \ldots \ldots$

4.7 Predicted Probabilities by Trade Share, Notice Periods After nine months of Service, $L=2 \ldots \ldots \ldots \ldots \ldots \ldots$

4.8 Predicted Probabilities by Trade Share, Notice Periods After 4 years of Service, $L=1$ and $L=2 \ldots \ldots \ldots \ldots \ldots \ldots$

4.9 Predicted Probabilities by Trade Share, Notice Periods After 20 of Service, $L=1 \ldots \ldots \ldots \ldots \ldots \ldots \ldots \ldots \ldots$ 


\section{Chapter 1}

\section{Introduction}

This thesis is comprised of three self-contained essays in international economics. The underlying theme throughout this body of work relates to the economic impacts of globally integrated markets. The first essay, presented in Chapter 2, empirically examines the impact of exchange rate volatility on exports for a sample of developing and transition economies. This is a question of significant policy relevance in such countries, especially since most have shifted dramatically from a policy of inward-orientation (and import-substitution) towards one of export-promotion. Furthermore, most industrialized nations today have some form of a floating rate, but developing and transition economies have been more inclined to experiment with a mix of regimes in recent years. For developing countries (typically plagued by weak monetary institutions) pegging the exchange rate is a way to create monetary credibility. In light of these observations, I use a panel of 72 countries over the 1991 to 2008 time period to estimate the impact of exchange rate volatility on real exports, controlling for various country-specific characteristics. Using three measures of volatility, I address the potential endogeneity of volatility and account for the dynamic nature of exports with Difference and System GMM estimation.

Chapters 3 and 4 address the impact of trade on labour standards. The growing prevalence of labour provisions in trade agreements highlights real-world concerns of 
a "race-to-the-bottom" (RTB) in labour standards among trading countries, particularly when trade involves developing countries. The concern is that without provisions to maintain labour standards, free trade will induce national governments to lower these standards as a way to reduce the production costs of domestic firms. This may trigger a RTB in labour standards as governments attempt to undercut each other to gain international market shares. This chapter assesses whether there is a theoretical basis for linking trade to a RTB in labour standards. Labour standards are modeled as minimum wages and are endogenously determined by assuming that they are put in place to constrain the firms' monopsony power in labour markets. On the trade side, the well-known Brander and Spencer international duopoly model of strategic trade policy (1985 JIE) is adapted to include decisions on minimum wages. Accordingly, the model allows us to assess if each government will use the labour standard to help its domestic firm gain a strategic advantage over its foreign rival - that is, whether strategic considerations lead to a race-to-the-bottom in minimum wages.

On the empirical side, Chapter 4 examines the impact of trade on employment protection, but through the lens of legal origin theory. This approach takes into account newer literature in the area of institutional economics which suggests that the legal tradition of a country shapes its approach to regulation, with countries of Common Law origins favouring markets and less regulation while those of Civil Law traditions tend towards more government intervention and regulation. Adapting legal origin theory to the trade and labour standards literature, I use a new dataset on employment protection containing a panel of 90 developing and developed countries to estimate the impact of trade openness on two alternate measures labour standards. These measures are both based on advance notice periods employers are required to give employees upon dismissal. Since this requirement varies by the length of an employee's tenure, I also consider notice periods for employee dismissals after nine months, four years and 20 years of service. The effects of legal origins are examined 
using two alternative classifications - one of which considers the role of colonial origins in shaping legal traditions more closely. Given the two alternative indicators of labour standards, two different econometric models are used - a Tobit model on raw notice periods (measured in months) and a four-choice ordered probit model on an ordinal ranking of the stringency of notice periods. This approach allows us to examine whether legal origins matter for notice period lengths, if there is a race-to-the-bottom in employment protection with greater trade openness, and whether this impact differs by legal origin.

Chapter 5 concludes the thesis. All references and appendices are found at the end of each chapter. 


\section{Chapter 2}

\section{On the Impact of Exchange Rate}

\section{Volatility and Exports: A Panel Data}

\section{Approach}

\subsection{Introduction}

From 1944 to 1973, members of the Bretton Woods system fixed their exchange rates against the U.S. dollar and a constant price of gold with the hopes of creating price stability following a volatile inter-war period. After the collapse of Bretton Woods in 1973 and the transition to flexible exchange rates that followed, economists were concerned with the possible detrimental impacts of a floating exchange rate. ${ }^{1}$ This concern reflected the larger debate of fixed (low exchange rate volatility) versus floating (higher exchange rate volatility) exchange rate regimes, with the latter representing a new source of uncertainty at the time (Aristotelous, 2001).

The impact of exchange rate volatility on international trade has garnered much attention from economists, but has achieved little consensus due to mixed results. Certainly, exchange rate volatility can impact a firm's trading activity. If firms cannot respond to fluctuations in the exchange rate in the short-run, sudden depreciations

\footnotetext{
${ }^{1}$ See for example Ethier (1973), Clark (1973), Hooper and Kohlhagen (1978), Akhtar and Hilton (1984), or Thursby and Thursby (1987).
} 
in the exchange rate reduce the value of export goods, thereby reducing profits of exporting firms. Similarly, a sudden appreciation of the exchange rate increases the costs of imports, thereby reducing profits of importing firms. Also, if a firm does not have the option to hedge exchange rate risk, either on forward exchange rate markets or through buying futures, a firm's output decision can be greatly influenced by fluctuations in the exchange rate through international transactions.

To date, the existing literature has largely focused on the impact of exchange rate volatility on trade for developed countries, with more recent work giving attention to the experience of developing countries and emerging markets. Most industrialized nations today have some form of a floating rate, while emerging market and developing countries have experimented with different exchange rate regimes in recent years. Many developing countries, for example, adopt a form of fixed exchange rates to promote macroeconomic stability (i.e., price stability). In the presence of weak monetary institutions, pegging the currency to a nominal anchor (and at a reasonable level) is a way for developing or emerging market countries to import monetary credibility (Bleaney and Franscisco, 2007). Furthermore, in the absence of well-developed foreign exchange and forward markets, firms in these countries may not be able to hedge exchange rate risk forward. From a policy perspective, the possible impacts of exchange rate volatility on trade are also relevant given that such countries have shifted dramatically from a policy of inward-orientation (and import-substitution) to one of export-promotion. Thus, the link between exchange rate volatility and trade is relevant from an economic development policy perspective, particularly in light of the positive impacts that trade may have on economic development (Bhagwati, 2007, p.60).

In this chapter, I examine the impact of exchange rate volatility on exports for a panel of 72 developing and emerging market countries. The focus on these countries rather than developed economies is a significant contribution to the existing literature 
on exchange rate volatility and trade. Furthermore, I estimate the impact of exchange rate volatility on exports for three alternative measures of volatility, one of which has not been used before in this context. It is also important to point out that most existing studies deal with only one or a small group of countries and use time series analysis. Very little has been done to exploit panel techniques using a larger sample of countries over time. Also, many previous studies have also not accounted for the potential endogeneity of volatility in the trade-volatility relationship, or the dynamic nature of the model. That is, very little existing work accounts for the possibility that countries wishing to foster trade through low exchange rate volatility may also take steps to increase trade through other avenues, such as lowering trade barriers (Tenreyro, 2007). Furthermore, exports by their nature are trending over time, and so period-to-period exports are likely related. I therefore exploit newer techniques in dynamic panel data analysis, namely Difference and System Generalized Methods of Moments (GMM) estimation, which seem to be better suited for panels of this type, on top of standard Fixed and Random Effects panel data models. These factors, along with the fact that I use more recent (up to 2008) data, make this study different from others.

In the following section, I outline the existing literature on the topic. Section 2.3 presents the proposed model, data, methodology and other estimation issues. Empirical results are presented in Section 2.4, and Section 2.5 presents a small extension to the empirical analysis. Section 2.6 concludes the study. All tables can be found in the Appendix at the end of the chapter. 


\subsection{Literature Review}

\subsubsection{Theoretical Work}

From a theoretical standpoint, there is little consensus on whether low exchange rate volatility promotes trade. Early theoretical studies focus on the impact of exchange rate risk on trade. Clark (1973) argues that exchange rate flexibility creates uncertainty for firms dealing in international markets, and thus depresses exports. In his model, he assumes that a firm's willingness to participate in international markets depends on the long-term profitability of doing so. An exporting firm faces a constant stream of profits in foreign currency, but variable in domestic currency. The forward market provides the only available hedging option, though is assumed to last less than the length of a contract (i.e., the planning horizon of the firm exceeds that of the forward exchange rate). Results from the model suggest that firms reduce export supply if they are risk averse when the variance in the forward exchange rate increases. Similar results are found in the model by Ethier (1973) who instead focuses on a firm's decision to import rather than export. There are two key results from Ethier's (1973) model. The first result shows that if firms face uncertainty regarding the future spot rate, but know profits with certainty, they reduce their imports by an amount that depends on the difference between the future and spot exchange rate (that is, independent of risk preference). If, on the other hand, the firm's profits vary depending on the realization of the future spot rate, firms will further reduce imports.

Hooper and Kohlhagen (1978) expand on the work of Clark (1973) and Ethier (1973). However, while previous models focused on supply (exports) and demand (imports) separately, the Hooper and Kohlhagen model incorporates both sides. For importing firms, assuming that contracts are fixed in the short-run, uncertainty arises when at least a non-zero proportion of imports are denominated in foreign currency, and not all imports can be hedged on the forward market. Uncertainty for exporting 
firms is present if a non-zero proportion of exports are sold in foreign currency and export sales cannot be fully hedged on the forward market. Results from solving import demand and export supply equations show that this form of uncertainty reduces trade volumes. Hooper and Kohlhagen further expand the model to account for the role of risk preference and exchange rate variability. They find that when exporters and importers are risk averse, an increase in exchange rate variability reduces the volume of trade.

An opposing, but equally plausible view is that exchange rate volatility may have a positive impact on trade. De Grauwe (1988) shows that exchange rate uncertainty can possibly have a positive impact on exports. In the model, an individual producer has the option to produce for foreign and domestic markets, and chooses the optimal labour allocation to maximize the expected utility of his total income. The author then examines whether an increase in exchange rate variability impacts the optimal resources allocated to the export sector. De Grauwe (1988) shows that if producers are risk averse, an increase in exchange rate risk increases export activity, while if firms are not very risk averse, the opposite is true. While these results are somewhat counterintuitive, the author argues that these responses are reflecting substitution and income effects. The substitution effect is relatively straight-forward - an increase in risk lowers the attractiveness of risky activities, and so export activity declines. The income effect, on the other hand, reflects the offsetting behaviour of risk averse firms who fear the worst case scenario. Thus when exchange rate risk increases, the firm increases exports to avoid a large decline in export revenue. If the income effect dominates the substitution effect, exchange rate variability can actually promote trade. Note, however, that whether the income or substitution effect prevails relies upon the degree or risk aversion, which itself is dependent upon the concavity of the producer's utility function to the exchange rate. The possibility of such substitution and income effects is also echoed in the work of Dellas and Zilberfarb (1993) who 
argue that consumers are more likely to export (save) to protect themselves against very low consumption of imported goods in the presence of higher exchange rate volatility when consumers are sufficiently risk averse. Thus, depending on the degree of risk aversion, a positive link between exchange rate volatility and trade is possible.

Bailey et al. (1987) argue that exchange rate volatility can deter trade where forward markets for foreign exchange do not exist and firms are risk averse, but they also point to a number of factors that could lead to positive impacts on trade. The authors suggest that opportunities to profit arise from specialized knowledge of fundamentals among businessmen who trade real goods. In particular, they argue that if goods traders anticipate the price of foreign currency to decline based on their specialized information, they can choose how much they hedge (i.e. selling futures) in anticipation of future trade commitments. These opportunities to profit based on "insider" knowledge on factors that impact the exchange rate can offset the negative impacts that the cost of exchange rate risk has on trade volumes.

Franke (1991) finds a positive link between exchange rate volatility and trade in a framework similar to option pricing, where firms export if the option is profitable. In his monopolistic competition model, an individual firm cares about its cash flow, which is dependent upon the real exchange rate, foreign price, trade volume, and real production cost. Firms also face exit and entry costs to the export market. In this model, if exchange rate volatility increases the present value of cash flows faster than exit and entry costs, firms will enter the international market sooner and exit later thus, the number of trading firms rises, and so does trade. This result relies on the convexity of the cash flow function in the log real exchange rate.

Broll and Eckwert (1999), Sercu and Vanhulle (1992), and Bonroy et al. (2006) also treat exports as an option, and similarly find a possible positive link between exchange rate volatility and trade. A positive link is also argued in Sercu (1992), who introduces friction into the firm's production decision through duties and transport 
costs rather than exit and entry costs as in Franke (1991). This result holds in both a competitive and monopolist framework.

Finally, some theoretical work shows no impact of volatility on trade. Dixit (1989) presents a general model to explain investment decisions in the face of uncertainty. He points to a firm's decision to enter or exit a foreign market in the presence of exchange rate fluctuations as an application of the model. Dixit argues that since entry and exit costs are sunk and cannot be recovered if a firm stops exporting, firms tend to wait as the exchange rate becomes more volatile, and lengthen the time in which neither exits nor entries occur. That is, inactive firms continue in their idleness, and active firms do not exit the market in the face of growing uncertainty - firms become unresponsive to exchange rate variability. Willett (1986), on the other hand, suggests that, in reality, international trade is unresponsive to exchange rate volatility, since the latter represents instabilities in local markets, rather than an increased chasm between international and domestic risk.

Bacchetta and Van Wincoop (2001) develop a two-country general equilibrium model examining the impact of exchange rate systems on trade and welfare. In particular, they develop a model to answer the question of whether a fixed exchange rate regime (i.e. exchange rate stability) promotes trade. In their benchmark model, firms are monopolistically competitive and there is a continuum of identical households facing a utility function that is separable in consumption and leisure. Additionally, households are required to carry cash (domestic and foreign) to make goods market purchases. The authors relate the exchange rate between two countries (home and foreign) to their relative money supplies, thus uncertainty about fundamentals like the money supply will lead to uncertainty in the exchange rate. In this way, the only shocks to the model are monetary ones. Results from this benchmark model show that trade is identical across fixed and flexible exchange rate regimes, suggesting that exchange rate stability has no impact on trade. 


\subsubsection{Empirical Work}

Given the ambiguity in the theoretical results, it is not surprising that there are mixed results in the empirical literature as well. In the large body of literature examining industrialized countries, a clear relationship between exchange rate volatility and trade has not been found. There is also a large body of literature on the effect of currency unions on trade. ${ }^{2}$ Rose (2002) for example has shown that the creation of currency unions improves trade among industrialized countries. ${ }^{3}$ However, currency unions do not necessarily create exchange rate stability - a country may have stability in exchange rates among a set of countries but instability with others

A number of authors have found a negative statistical relationship between volatility and trade in industrialized countries. These include papers by Hooper and Kohlhagen (1978), Akhtar and Hilton (1984), Chowdhury (1993) and Kenen and Rodrick (1986). However, there are just as many authors who have found ambiguous results that is, a negative relation for certain model specifications and a positive relation for others. These results are found in works by Bailey et al. (1987), Cushman (1983), and Koray and Lastrapes (1989). Bini-Smaghi (1991) reviewed these works on industrialized countries, and found that when he limited the Hooper and Kohlhagen (1978) analysis to commodity groups, a more robust negative impact of exchange rate variability on trade was found.

Studies focusing on developing countries and/or transition economies have only recently attracted the attention of researchers, with the recognition that the experience in such countries need not be similar to those in industrialized nations. First analyses on developing countries used simple techniques like OLS on a cross-section of

\footnotetext{
${ }^{2}$ Andrew Rose has been a major contributor to this literature. See for example, Rose (2000, 2002), Rose and Stanley (2005) and Rose and Glick (2002).

${ }^{3}$ It should also be pointed out that the creation of a currency union does more than fix an exchange rate between countries - it also reduces transaction costs relative to trade. Thus it is a contributing factor to increased trade flows (Clark et al., 2004).
} 
countries or pooled OLS for a single country or subset of countries over time. Brada and Mendez (1988) use a bilateral gravity model of trade augmented by dummy variables indicating whether each country pair are under a fixed or floating exchange rate regime, for a sample of 30 developed and developing countries from 1973 to 1977 (post-Bretton Woods). In their empirical model, the coefficient on the floating regime dummy represents the increased uncertainty created by a floating rate regime over and above that experienced by traders in a fixed exchange rate regime. Though there is no direct measure of volatility, the authors find that bilateral trade flows between two countries with floating regimes were actually higher than those with fixed rates.

Bahmani-Oskooee (1991) and Bahmani-Oskooee and Ltaifa (1992) use export and import demand equations to estimate the impact of exchange rate volatility on trade for a subset of developing countries. In both papers, the standard deviation of the quarterly percentage changes of the real exchange rate for the eight previous quarters is used as a measure of exchange rate volatility. In the 1991 paper, Bahmani-Oskooee finds that volatility negatively impacts imports in South Korea, Thailand, Turkey, and Pakistan, and negatively impacts exports for Greece and Turkey. The author finds a positive and significant impact on exports from Brazil and South Korea. Bahmani-Oskooee and Ltaifa (1992) find that between 1973 and 1980, aggregate exports of developed countries are less sensitive to exchange rate volatility compared to developing ones. For the 19 developing countries in the sample, the authors also find that those with fixed exchange rates to a major currency (i.e. the U.S. dollar or French Franc) were found to have less exchange rate risk than others.

Kumar and Dhawan (1991) examine the impact of volatility on bilateral exports from Pakistan to its major trading partners, which are a set of industrialized countries, from 1974 to 1985 . The authors use several measures of nominal and real exchange rate volatility in an export demand function. These measures include a 
within period standard deviation, moving average of the standard deviation, the coefficient of variation, and the Gini mean difference in nominal and real exchange rates. The authors also account for possible third country effects by using the standard deviation of the exchange rate for major trading partners not included. Results from OLS regressions point to evidence of a negative impact, particularly for volatility in nominal exchange rates. The authors also find third party exchange rate effects to be significant determinants of export levels, and improve the robustness of the estimated equation.

While the previous studies show an overall negative effect of volatility on exports, Medhora (1990) finds no effect on imports. The author examines imports of members of the West African Monetary Union between 1976 and 1982. Using the standard deviation of spot rates, results from pooled OLS regressions on import demand equations suggest that there is no effect of bilateral exchange rate volatility on imports.

More sophisticated time series analyses emerged in the late 1990s, leading researchers to address potential problems in OLS analysis arising from trending variables and the need to distinguish between short- and long-run effects. Indeed, most authors suggest that early studies using OLS analyses likely suffer from the problem of spurious correlation, due to possible non-stationarity in variables. As a result, a significant body of research has used cointegration and error correction models to deal with the shortcomings of OLS analysis. Using such models, Arize (1996) shows that real exchange rate uncertainty had negative impacts on Korean exports both in the short- and long-run from 1973 to 1993 . This methodology and results are further echoed in Arize (2000) for a sample of thirteen developing countries, Arize (2003) for a sample of eleven developing countries, and Arize (2008) for Latin American countries.

Using cointegration and error correction models as well, Baak et al. (2007) finds that bilateral exchange rate volatility has a negative impact on exports from East 
Asian countries to Japan and the United States. The authors find a negative long-run impact on exports flows from South Korea, Singapore and Thailand using cointegration analysis. Evidence from error correction models suggest that only Singaporean exports to Japain are adversely impacted by exchange rate volatility. Doğanlar (2002) finds both long and short-run negative impacts of volatility on exports for Turkey, South Korea, Malaysia, Indonesia, and Pakistan. Somewhat mixed results are found in Poon et al. (2005), who examine short- and long-run relationships between exchange rate volatility and export demand in Indonesia, Japan, South Korea, Singapore, and Thailand. The authors find that all variables are cointegrated for each country, suggesting a long-run relationship. Results suggest that volatility negatively impacts exports for three out of the five economies in the short-run as well.

Similar methodologies are mirrored in single country works, such as those for Indonesia (Siregar and Rajan (2004)), Turkey (Vergil (2002)), South Africa (Todani and Munyama (2005)), Mexico (Bahmani-Oskooe and Hergerty (2009)) and, China (Bahmani-Oskooee and Wang (2007)). Siregar and Rajan (2004) find that using the moving standard deviation and the GARCH conditional variance as measure of volatility, exchange rate risk negatively impacts exports and imports in Indonesia in the 1990s (excluding the crisis period). The authors also find evidence of a cointegrating relation, suggesting a long-run relationship between volatility and trade. Vergil (2002) finds that, using the standard deviation of the change in the real exchange rate as a measure for volatility, exchange rate risk overall negatively impacts Turkish export flows to the U.S. and major trading partners in the European Union. Evidence from both cointegration and error correction models suggest a negative relationship between exchange rate volatility and Turkey's real exports to its major trading partners in the long-run, while the impact for the short-run was only significant and negative for trade with Germany.

Todani and Munyama (2005) find that the impact of volatility on South African 
exports depends the measurement of exchange rate volatility. They generally find no statistically significant relationship between exports and exchange rate volatility; a positive relationship is found only in one out of several measures of volatility. Bahmani-Oskooee and Hegerty (2009) find evidence of a negative impact of exchange rate volatility on commodity trade between Mexico and the U.S. in the short-run, but weaker effects in the long-run. Agricultural trade and textile imports in particular show an adverse sensitivity to exchange rate volatility. Using the same methodology, Bahmani-Oskooee and Wang (2007) find that for U.S. - China trade, exchange rate volatility negatively impacts U.S. imports from China, but has a positive impact on exports.

Doroodian (1999) addresses the non-stationarity issue of exchange rates in a different manner. The author uses a Hodrick-Prescott (HP) filter to de-trend the log real exchange rate, and then use a combined ARIMA-GARCH approach to estimate conditional variances to measure exchange rate volatility. Using this measure of volatility, Doroodian estimates an export demand equation for India, Malaysia and South Korea from 1973 to 1996. Results suggest a strong negative impact of volatility on exports, particularly for Malaysia.

Most empirical studies just described use some form of time series analysis. This is largely because these analyses have used a small subset of countries or have confined their analysis to one country. These approaches rely on the researcher's ability to access longer and/or higher frequency time series data, which are ideal for time series analysis. Panels for many countries over long periods are simply not available. In light of this, with such panels, greater attention can be given to panel estimation techniques. Some studies have attempted to exploit the panel data techniques rather than focusing solely on the time series component. Chit (2008) and Chit et al. (2008) examine the impact of exchange rate volatility on bilateral exports for East Asian countries. The former focuses on bilateral exports within the ASEAN-China free 
trade agreement from 1982 to 2005, while the latter looks at bilateral exports of a set of emerging East Asian economies to the industrialized world from 1982 to 2006. In both cases, the authors use a general gravity model of trade, and estimate it with fixed and random effects. Volatility is measured by the standard deviation of percent changes of the bilateral exchange rate, though Chit et al. (2008) also uses the moving average standard deviation and the conditional variance estimated from a GARCH model. Both papers confirm a long-run cointegrating relationship among the variables. Results from fixed and random effects suggest there is a negative impact on exports in both papers.

Égert and Morales-Zumaquero (2008) examine the impact of exchange rate volatility on trade in ten transition economies in Central and Eastern Europe from 1990 to 2003 using both a time series (individual country) and panel study approach. Evidence from the entire panel point again to a significant and negative relationship between exchange rate volatility and exports. In particular, the authors find that manufacturing exports are significantly deterred by more exchange rate volatility in Central and Eastern Europe.

In a larger panel, Sauer and Bohara (2001) look at a sample of 91 countries, including 69 developing economies, from 1966 to 1993. They use three measures of volatility in an export demand equation, including the conditional variance, moving standard error if the exchange rate is assumed to follow an $\operatorname{AR}(1)$ process, and the moving standard error from a trend model. Exchange rate volatility is measured against each country's ten major trading partners. Using both random effects and fixed effects on an (aggregate) export demand equation, they find that real exchange rate volatility has a negative impact on exports in many developing countries but has no impact in Asian and industrialized countries. These results are robust to multiple specifications of their model of export demand and measures of volatility.

Tenreyro (2007) addresses some major issues in the exchange rate and volatility 
literature that have not been dealt with in most of the previous papers. Firstly, there is a potential endogeneity problem inherent in the basic research question. Two countries who wish to increase bilateral trade through lower exchange rate volatility may follow steps to promote integration. This may lead to bias in coefficient estimates, particularly in OLS regressions. Furthermore, heteroskedasticity is also a problem in many studies. Also, the popular use of the gravity model in logs can frequently exclude countries who do not trade at all (i.e. zero bilateral trade) if not using a model that takes these zeroes into account. To address these problems, the author uses trade in levels, and implements Maximum-Likelihood-IV estimation on a broad sample of countries, from 1970 to 1997 . Results from this study point to no significant impact of exchange rate volatility on the level of exports.

A very recent paper by Omojimite and Akpokodje (2010) examines the impact of volatility on trade for a sample of African countries from 1986 to 2006, using Difference/System GMM estimation. Using the conditional volatility of exchange rates estimated from GARCH equations, the authors find a negative impact of exchange rate volatility on exports. This impact appears to be larger for countries belonging to the Communauté Financière Africaine (CFA) than Non-CFA countries. The strength of these results are unknown, however, as instrument counts are not reported, and robust standard errors were not used. We will see in this chapter that controlling the number of instruments is a critical feature of Difference and System GMM estimation, as using too many instruments can lead to false positives (Roodman, 2009).

The ambiguity in both the theoretical and empirical results support the need for more empirical analysis. It is within this context that I explore the relationship between exchange rate volatility and trade in a group of developing countries and emerging markets. In the next section, I present the proposed model and describe the data and variable measurements, and the estimation techniques used in the analysis. 


\subsection{The Model, Data and Methodology}

\subsubsection{The Empirical Model}

The goal of the empirical analysis is to measure the impact of exchange rate volatility on trade. In the literature, the choice of the empirical model applied has relied on whether one focuses on bilateral or aggregate exports. For studies comprising of a few countries, authors have looked at the impact of bilateral exchange rate volatility on bilateral exports. Thus, such papers have largely used gravity models, where bilateral exports are said to also depend on variables like country size, distance from trading partners, and whether countries share a common border.

With a large international cross-section, gravity models are more difficult to implement empirically because they require data on bilateral flows for every pair of countries. Many authors have, therefore, focused on a long-run aggregate export demand equation with a larger sample of countries. The model adopted here is a hybrid of those commonly used by previous researchers and focuses on aggregate exports. Note that the focus on exports rather than imports is deliberate. Firstly, this is in line with most of the literature. Secondly, exports are more interesting from a policy perspective - given the focus on export-led development in many developing countries, results from this chapter may be able to point to the potential role for exchange rate policy in stimulating exports. Thus, I adopt a conventional aggregate export demand function that also includes country size effects emphasized by gravity models. Specifically, the general model I employ can be written as:

$$
X=f(Y, R P, V, S)
$$

In equation (2.1), $X$ represents the volume of exports, $Y$ is foreign real income, $R P$ stands for the price of export goods relative to the price of competing foreign goods, $S$ is a measure of the size of the domestic economy, and $V$ is a measure of exchange 
rate volatility. The inclusion of the foreign income and the price variables follow from standard demand considerations. We would expect that real exports would be positively related to foreign real income and negatively related to the domestic price of exports relative to competing foreign good prices. Following the standard interpretation of a gravity model, ceteris paribus, a country's economic size should positively impact exports - that is, a large economy is expected to export more since such countries have more goods available to do so. As we have noted, the impact of volatility is ambiguous.

For empirical purposes, we need an explicit function of (1). I adopt a double$\log$ specification, with the exception of the volatility variable, which permits an easy interpretation of the coefficients. ${ }^{4}$ Equation (2.1) can thus be rewritten as:

$$
\ln X_{i t}=\beta_{0}+\beta_{1} \ln Y_{i t}+\beta_{2} \ln R P_{i t}+\beta_{3} V_{i t}+\beta_{4} \ln S_{i t}+u_{i t}
$$

In equation (2.2), $i=1,2, \ldots, N$ denotes countries, $t=1,2, \ldots, T$ denotes years, and $u_{i t}$ is the random disturbance. On prior grounds, we expect $\beta_{1}, \beta_{4}>0$, and $\beta_{2}<0$, while the sign of $\beta_{3}$ is ambiguous. Note, however, for the reasons noted earlier, it is anticipated that $\beta_{3}<0$ for developing countries. That is, higher exchange rate volatility is expected to reduce real exports.

It is important to point out, however, to improve accuracy of our estimates in (2), we should also account for the possibility of J-curve effects of relative prices on exports since we will measure this variable using the real effective exchange rate (to be developed in the next section). According to the J-curve hypothesis, a country's trade balance will initially worsen following a depreciation in the exchange rate, as volumes are slow to respond to the price change. In the long-run, the trade balance improves, as demand elasticities for exports and imports increase. ${ }^{5}$ The initial worsening of the

\footnotetext{
${ }^{4}$ All volatility proxies are measured in terms of $\log$ differences, as we will see shortly.

${ }^{5}$ The Marshall-Lerner condition states that the sum of export and import demand elasticities
} 
trade balance is due to lags in the production process, delivery lags, and imperfect dissemination of prices to both producers and consumers (Caves et al., Chapter 16, 2002). In the case of exports, exporting firms may require time to adjust their production as demand for exports slowly grows. Thus, while initially export volumes may be non-responsive or highly inelastic to the real exchange rate change, over time, exports begin to rise (imports begin to fall), and the trade balance improves. Similarly, there is an inverse $\mathrm{J}$-Curve effect following the appreciation of the exchange rate. Immediately following an appreciation, the trade balance initially improves, with little or no response of exports. In the long-run, exports decline as demand for exports fall and firms are able to adjust their production. It is possible then, that lagged relative prices, which are measured by the real exchange rate, impact exports as well. Thus (2) is simply augmented by a lagged relative price variable.

Finally, if there is any persistence in the data, it is entirely possible the relationship described in (2) is a dynamic one - that is, current exports might depend on lagged exports. Eichengreen and Irwin (1997) have pointed to lagged values of trade as being an important determinant of current trade flows. It is therefore necessary to also consider the dynamic version of (2) in which we introduce not only lagged relative prices, but also lagged exports:

$$
\ln X_{i t}=\alpha_{0}+\alpha_{1} \ln X_{i t-1}+\alpha_{2} \ln Y_{i t}+\alpha_{3} \ln R P_{i t}+\alpha_{4} \ln R P_{i t-1}+\alpha_{5} V_{i t}+\ln S_{i t}+e_{i t}
$$

Thus, based on equation (2.3), we would anticipate that $\alpha_{5}<0$. If exports are persistent, we would expect $0<\alpha_{1}<1$. An increase in relative prices (proxied by the REER) represents an appreciation. If there are J-curve effects, current exports can

to the exchange rate is greater than one, so that overall, a depreciation (appreciation) should improve (worsen) the trade balance. If there are J-Curve effects, this means that the Marshall-Lerner condition fails in the short-run, but is satisfied in the long-run. 
either not respond to a current real exchange rate appreciation, or it could decrease slightly, given its relative inelasticity in the short-run. As elasticity of export demand increases over time, therefore, the absolute magnitude of the coefficient on the lagged exchange rate (relative prices) should be larger. Thus we would anticipate that $0 \leq$ $\left|\alpha_{3}\right|<\left|\alpha_{4}\right|$.

\subsubsection{The Data and Measurement}

Rather than focusing on a small set of countries over a long time horizon like the bulk of the literature, this chapter uses data for a panel of developing countries and emerging markets over a number of years. The panel is "short and wide" in that there are many countries (72) but fewer years (1991-2008). 1. The focus on a large number of countries but fewer years is deliberate. First, it allows access to a larger sample size compared to most of the literature. More importantly, while previous studies have focused on the time series properties of exchange rate volatility and trade, the estimation procedure employed in this chapter focuses on the endogeneity of volatility and the persistence of exports. Thus, estimation techniques (developed further in this section) that handle such panel data properties are better suited to samples with larger $N$ than $T$.

The variables are drawn directly or constructed from the World Bank's Global Economic Monitor database (GEM) and the UN Data online database that compiles datasets from various UN agencies. The list of countries used in the paper is given in Table 2.1 in the Appendix. Before discussing the estimation methodology in the next section, I outline how each of the variables used are measured. Real exports are measured in constant 1990 U.S. dollars. Foreign demand $(Y)$ is measured as the world's GDP in constant 1990 U.S. dollars, net of domestic GDP. Following Chit et al. (2008), domestic real GDP is used as a measure of a country's economic size $(S)$.

In measuring the relative price variable, ideally we would use export prices relative 
to competing foreign prices:

$$
R P_{i t}=P_{i t} / P_{i t}^{*}
$$

In the above equation, $P_{i t}$ represents domestic prices of export goods and $P_{i t}^{*}$ represents foreign prices of competing goods. Note that $P_{i t}$ and $P_{i t}^{*}$ need to be measured in the same currency to be relevant. Lacking the requisite data on such prices, we need to determine an adequate proxy. Let $e$ be the nominal exchange rate representing foreign currency units per unit of domestic currency (i.e. indirect quotation). Thus, one way to convert prices to the same currency is as follows:

$$
R P_{i t}=P_{d i t}^{*} / P_{i t}^{*} ; \quad P_{d i t}^{*}=e P_{i t}
$$

where $P_{d i t}^{*}$ is the price of exports in foreign currency, and $P_{i t}^{*}$ represents price of competing goods in foreign currency. Thus, according to equation (2.5), we can see that relative prices can be interpreted as the real exchange rate. The use of the real exchange rate is common in the literature since it appears to be a valid measure of price competitiveness. Simply put, the real exchange rate measures the rate at which goods and services can be traded across countries. Thus, if a domestic currency is weak in real terms, this implies that domestic goods are sold more easily abroad. Note, however, that the appropriate real exchange rate measure is really the real effective exchange rate since this takes into account the nominal exchange rates of a countrys major trading partners. As a result, one would expect that movements in the real effective exchange rate (REER) are a better indicator of a nation's price competitiveness than a bilateral real exchange rate.

Given the availability of real effective exchange rates from the GEM database, I use the $(\log )$ real effective exchange rate as a measure of relative prices. ${ }^{6}$ The REER is

\footnotetext{
${ }^{6}$ The real effective exchange rate available from the GEM database is based on the same measure
} 
constructed from the nominal effective exchange rate (NEER), adjusted for changes in relative Consumer Price Indices. The NEER index (on which the REER construction is based) is the ratio of the average nominal exchange rate of a country's currency to a weighted geometric average of currencies from the Euro area and selected other countries. Note that the individual bilateral exchange rates included in the NEER are measured by indirect quotation. Thus an increase in the exchange rate represents an increase in the value of the local currency units (appreciation) and a decrease in the exchange rate is akin to a decline in the value of the local currency (depreciation). The real effective exchange rate will therefore have the same properties - an increase (decrease) in the REER is an appreciation (depreciation) of the local currency and should reduce (increase) exports.

\section{Measuring Volatility}

There is no unique way to measure exchange rate volatility and many different specifications have been used in the literature, ranging from a simple standard deviation of an exchange rate, to examining the difference in exchange rates relative to a time trend. Since many previous studies focused on a smaller set of countries over a longer time horizon, many authors have used ARCH or GARCH procedures to measure volatility via the conditional variance. There is also the question of whether to use nominal or real exchange rate volatility. Some authors have pointed out that nominal is preferred to real exchange rate volatility, as the latter captures not only fluctuations in the nominal exchange rate, but also in relative prices. ${ }^{7}$ Empirically, however, Qian and Varangis (1994) have shown that movements in nominal and real exchange rates have not differed substantially in the post-Bretton Woods era. In a survey of the literature, McKenzie (1999) has also noted that the distinction between

${ }^{7}$ See for example, Bini-Smaghi (1991) or Akhtar and Spence-Hilton (1984). 
real and nominal exchange rates do not change empirical results significantly. Thus, real exchange rate volatility is the preferred measure in this chapter. Furthermore, given the focus on aggregate exports, volatility of the real effective exchange rate is the appropriate measure of exchange rate risk. As mentioned above, the real effective exchange rate is a trade-weighted index of bilateral exchange rates adjusted by relative consumer prices. Thus volatility of the REER captures movements in exchange rates with multiple countries, and is likely to impact aggregate exports more than the volatility of a single (bilateral) exchange rate.

Based on monthly REER data, I construct three (annual) measures of exchange rate volatility. The first two measures are in line with the existing literature. Following Chit et. al. (2008), the first measure of volatility is the standard deviation in the first difference of the log real effective exchange rate. Thus for each year $t$ and country $i$, we have the following:

$$
V_{1, i t}=\left[\sum_{s=1}^{m_{i}}\left(\Delta \ln R E E R_{i s}-\theta_{i}\right)^{2} /\left(m_{i}-1\right)\right]^{\frac{1}{2}}
$$

In the above equation, $R E E R_{i s}$ is the real effective exchange rate for country $i$ in month $s, \theta_{i}$ is the mean of the first differences of the $(\log )$ real effective exchange rate $\left(\triangle \ln R E E R_{i s}\right)$, and $m_{i}$ is the number of months. The second measure of volatility also follows the literature and is the 12-month moving average standard deviation (MASD) of the log real effective exchange rate. This measure captures persistence in exchange rate movements. For each country $i$ and year $t$ we have:

$$
V_{2, i t}=\left[\frac{1}{m_{i}} \sum_{j=1}^{m_{i}}\left(\ln R E E R_{i s+j-1}-\ln R E E R_{i s+j-2}\right)^{2}\right]^{\frac{1}{2}}
$$

In equation (2.7), $m_{i}$ is the order of the moving average, which is up to 12 months in this case. Note that this measure of volatility captures the movement of exchange 
rate risk over time. Following Koop (Chapter 12, 2006), one can define volatility as the square of the deviation of first differences of the exchange rate from the mean of those first differences. Thus, for each country $i$ and month $s$, we may consider the following:

$$
V_{3, i s}=\left(\Delta \ln R E E R_{i s}-\theta_{i}\right)^{2}
$$

where $\theta_{i}$ is the mean of the first differences of the $(\log )$ real effective exchange rate. Taking the supremum of (8), we have an annual volatility measure:

$$
V_{3, i t}=\sup \left\{\left(\Delta \ln R E E R_{i s}-\theta_{i}\right)^{2}\right\}
$$

The measure $V_{3, i t}$ serves as the third proxy for exchange rate volatility, and has not been used in the literature to date. To be consistent with existing work, all three measures are used as proxies for exchange rate volatility in the empirical analysis. ${ }^{8}$ For simplication, we drop the country and time subscripts when referring to these volatility measures.

There is little consensus on what proxy of exchange rate volatility is superior. Bini-Smaghi (1991) argues that while the MASD $\left(V_{2}\right)$ is a relatively popular measure used in the literature, it actually distorts volatility by looking too far into the past. $\mathrm{He}$ argues that exchange rate variability does not show long autocorrelation, thus there is actually very little persistence in volatility movements. Measure $V_{2}$ is adopted only to be consistent with existing literature, but as we will see, it performs poorly in the empirical analysis.

Volatility measure $V_{3}$ emphasizes behaviour in exchange rate changes that should be reflected in any proxy for volatility. First, it takes a value of zero if exchange rates

\footnotetext{
${ }^{8} \mathrm{ARCH} /$ GARCH measures of the conditional variance were explored as well, but were not possible. The conditional variance could only be estimated for a very small subset of countries, thus it was not a suitable measure of volatility in this study.
} 
follow a constant trend, and thus can be perfectly anticipated. Any non-zero values represent unanticipated movements in the exchange rate and therefore represent exchange rate risk. Secondly, $V_{3}$ captures high frequency changes in the exchange rate per year, thus represents short-run volatility. This is more suitable to the short time dimension of the dataset used in this study. Finally, extreme swings in the exchange rate are reported as large positive values in this measure.

Many of these characteristics are reflected in $V_{1}$ as well, however, there are a couple noteworthy points substantiating the use of $V_{3}$ over $V_{1}$ as a measure of volatility. Note that annual observations for $V_{3}$ represent the highest month-to-month volatility in a given year. Thus an increase in $V_{3}$ actually represents a larger swing in the exchange rate than an increase in $V_{1}$, which simply measures the average deviation of monthly changes in the log REER relative to its mean. Furthermore, the popular use of the standard deviation $\left(V_{1}\right)$ in the literature may not be justified given that changes in exchange rates tend to have distributions with heavy tails and do not follow a normal distribution. Thus, distribution-dependent measures like the standard deviation may be inappropriate (Boothe and Glassman, 1987). Volatility proxy, $V_{3}$, though it is mean-dependent, accounts for fatter tails by giving more importance to extreme swings in the exchange rate.

Tables 2.2 and 2.3 in the Appendix provide summary statistics for the key variables in the sample. The first row of Table 2.2 shows averages for all three measures of volatility. Note that by multiplying these values by 100 , we can approximate volatility in percentage terms. Thus, average volatility in the sample ranges from 0.8 percent $\left(V_{2}\right)$ to 2.7 percent $\left(V_{1}\right)$. We see that the average for $V_{3}$ falls in the middle of the other two measures, with an approximate percentage value of 1.6 percent. Volatility measures $V_{1}$ and $V_{2}$ show much smaller dispersions, with standard deviations of 1.4 and 2.0 percent respectively. Volatility measure $V_{3}$ has the largest standard deviation of 11.1 percent. 
It is important to point out that since this study fits into the larger debate on fixed versus floating exchange rates, we can take a closer look at how volatility varies across regimes. Indeed, the underlying argument in this chapter lies on the premise that floating regimes exhibit higher exchange rate volatility compared to fixed ones. The IMF has been the traditional source for information on the classification of countries by exchange rate regime. However, the IMF relies on de jure classification of regimes - that is, the exchange rate regime that is officially reported by countries. In Levy-Yeyati and Sturzenegger (2005), the authors construct a de facto exchange rate regime classification system - what countries actually follow. As the authors point out, de jure and de facto regimes often differ, since the exchange rate policy that countries actually follow (de facto) is not often what they follow in theory (de jure). The authors therefore classify countries into fixed or flexible exchange rate regimes based on changes in the nominal exchange rate, volatility of these changes, and how volatile international reserves are. Using this classification system, Table 2.2 also shows average exchange rate volatility by regime. ${ }^{9}$ As one would expect, we see quite readily that exchange rate volatility is higher in floating regimes than in fixed ones, with average volatility at around one percent or lower for fixed regimes, and ranging from one to 3.3 percent for floating regimes.

Finally, in Table 2.3 we can see that average log real exports is approximately 8.1 . The smallest average exports in the sample (1.01) belong to Kiribati. Not surprisingly, China is on average the largest exporter, with log real exports around 13.9. A similar pattern is found for domestic real GDP (also in logs).

\footnotetext{
${ }^{9} \mathrm{~A}$ "Fixed" exchange rate regime here is categorized as one that exhibits high volatility in international reserves, as international reserves are used to reduce volatility in the nominal exchange rate. A "Floating" exchange rate regime is characterized by large volatility in nominal echange rates, and stable reserves. Note that "Floating" includes both intermediate and pure float regimes.
} 


\subsubsection{Estimation Considerations and Methodology}

\section{Panel Unit Roots and Cointegration}

While panel data sets are particularly useful in analyzing cross-country phenomena over time, the time series component requires us to examine the possibility of nonstationarity in the variables. If variables follow a unit root, the empirical results can be masked by a spurious relationship. In the presence of non-stationary variables, we may then use panel cointegration tests to determine whether there is a long-run relationship between the variables. To this end, I employ two panel unit root tests - the Im, Pesaran, and Shin (2003) (IPS) and the Hadri (2003) Lagrange Multiplier tests. The main advantage of the IPS test is that the persistence parameter is allowed to vary across countries $\left(\rho_{i}\right)$. The IPS test statistic is an average of the individual Augmented Dickey Fuller (ADF) test statistic for a unit root. The null hypothesis is that $\rho_{i}=0$ for all $i$ (all series are non-stationary) against the alternative that $\rho_{i}<0$ for at least one $i$ (at least one series is stationary).

The Hadri Lagrange Multiplier test, on the other hand, has a null hypothesis that all series are stationary against an alternative hypothesis that at least one series contains a unit root. Unlike most panel unit root tests, the Hadri LM test reverses the null and alternative hypotheses in recognition that strong evidence is needed to reject the null hypothesis, and thus serves as an additional check for stationarity. The major drawback of this test is that it is better suited for panels with large $T$ and more moderate $N$, which is clearly not the case in this chapter. Also, a major limitation of many of this (and other) tests is the asymptotic properties, where $T$ is required to tend to infinity, while $N$ is either fixed or tending to infinity sequentially. Another limitation of this test is that the panel must be strongly balanced, and so I can only apply it to a balanced subset of my data. Given these drawbacks, all unit root tests should be interpreted with caution. 
If variables are suspected to follow first order autoregressive $(I(1))$ processes, Westerlund's (2007) four tests for cointegration are used to determine whether a long-run relationship between the integrated variables exists. That is, while variables in the model may be integrated of the same order (i.e., I(1)), a linear combination of these variables may be stationary. The Westerlund (2007) four test statistics allow us to determine whether at least one individual unit is cointegrated within the panel, and also whether the panel as a whole is cointegrated. In other words, these tests rely on determining whether there exists an error correction to an individual panel member or the panel as a whole. The advantage of Westerlund's (2007) four tests is that they more flexible compared to residual-based tests which tend to suffer from low power (Westerlund, 2007). ${ }^{10}$

\section{Estimation Methodology}

The simplest estimation procedure is to use the pooled ordinary least squares estimator (OLS). However, in the context of panel data, this estimator is inappropriate and more general estimation methods with better properties are possible. In relatively wide and short panels such as the one used in this study (that is, where the number of cross-sectional units is much larger than time periods), the OLS estimator does not take into account unmeasured differences across cross-sectional units. These time-invariant differences would be especially relevant when the cross-sectional units are economies which likely differ in the nature of economic, social and political institutions. A simple way of accommodating this would be to use dummy variables that classify countries according to their economic, political or social characteristics.

\footnotetext{
${ }^{10}$ Pedroni's (2004) test for example is residual-based. Such tests require that both the short-run error correction for the integrated variables in differences and the long-run cointegrating vector for these variables in levels are equal.Failure of this common factor restriction can lead to low power. This restriction is not required in Westerlund's (2007) tests, where the underlying dynamics are structural rather than residual. Thus, both the short-run and long-run parts of the error-correction model are allowed to be heterogeneous.
} 
A more general approach would be to first take the simpler model in (2) (including a lagged relative price variable) and make the intercept country-specific. The following could therefore be estimated as a Fixed or Random Effects model:

$$
\ln X_{i t}=\beta_{1} Y_{i t}+\beta_{2} \ln R P_{i t}+\beta_{3} R P_{i t-1}+\beta_{4} V_{k, i t}+\beta_{5} \ln S_{i t}+u_{i t}
$$

$$
\text { for } k \epsilon\{1,2,3\} \text { and } u_{i t}=\mu_{i}+\nu_{i t}
$$

In the above equation, $\mu_{i}$ is the country-specific intercept, $\nu_{i t}$ is the idiosyncratic error term, and $k$ indicates the measure of volatility being used. It is important to point out, however, that panel data is likely to suffer from the problem of timewise autocorrelation. If we expand the above model to also account for first-order autoregressive disturbances, we have that $\nu_{i t}=\rho \nu_{i t-1}+z_{i t}$ where $z_{i t}$ is identically and independently distributed with mean zero and variance $\sigma_{z}^{2}$. Equation (2.10) can be estimated to account for $\operatorname{AR}(1)$ disturbances using the within estimator of the Fixed Effects model, or the Baltagi-Wu (1999) GLS Random Effects model. In the Fixed Effects (FE) model, the individual specific effect is treated as non-stochastic, while in Random Effects (RE) models they are treated as random variables. For the latter, Baltagi and Wu (1999) propose using feasible generalized least squares as a weighted least squares method to ensure homoskedasticity in the error term and remove any serial correlation. Both the $\mathrm{RE}$ and $\mathrm{FE}$ procedures also have the benefit of being suitable for unbalanced data, which is characteristic of the dataset used in this chapter.

There are reasons to believe that the FE model is preferred to Random Effects. First, the Random Effects approach is suitable when the sample of units is randomly 
drawn. This is generally not the case in international panel data such as ours. Second, the $\mathrm{RE}$ estimator is not consistent when unmeasured heterogeneity is correlated with explanatory variables - a condition that could be present in our data set. For instance, unmeasured inter-country differences in factors such as the exchange rate regime and the quality of monetary institutions, are hardly to be independent of the explanatory variables, especially of exchange rate volatility. The fixed effects estimator does not suffer from this problem. However, while usually a Hausman test can help determine whether $\mathrm{FE}$ or $\mathrm{RE}$ are valid, it is important to point out that it is problematic to use this test in the presence of persistent data. That is, the Hausman test is not robust to the underlying dynamic properties of the data. Since export data used in this study are highly persistent, suggesting a dynamic model, both FE and RE models will be inconsistent. Thus, both FE and RE model results are reported in estimating equations (2.10) since Hausman tests are unreliable in this context.

Expanding the analysis to account for not only the possibility of country-specific effects but also the dynamic nature of exports, we may re-write equation (2.3) as follows:

$$
\ln X_{i t}=\alpha_{1} \ln X_{i t-1}+\alpha_{2} \ln Y_{i t}+\alpha_{3} \ln R P_{i t}+\alpha_{4} \ln R P_{i t-1}+\alpha_{5} V_{k, i t}+\ln S_{i t}+e_{i t}
$$

$$
\text { for } k \epsilon\{1,2,3\} \text { and } e_{i t}=\gamma_{i}+\eta_{i t}
$$

Note that traditional panel methods (such as the FE or RE model) lead to inconsistent and biased estimators in a dynamic panel model with fixed effects (equation (2.11)). The lagged dependent variable (exports) is now correlated with the time-invariant 
fixed effect $\left(\gamma_{i}\right)$. In the presence of persistent data (i.e., when $0<\alpha_{1}<1$ ), the BaltagiWu (1999) GLS method may be problematic. Furthermore, so far we have assumed that exchange rate volatility is exogenous to the level of trade. That is, we have assumed that exchange rate variability is randomly assigned to countries. It may be the case that countries who wish to improve their exports through lower exchange rate volatility might also pursue policies that encourage more trade integration (Tenreyro, 2007). Therefore, there is a possible simultaneity problem in the models presented. Finally, fixed effects models are typically suited for panels of large $N$ and $T$, and are biased in the presence of a lagged dependent variable. Thus, we require an empirical strategy that not only accounts for country-specific effects, but one that also accounts for the dynamic nature of the model. This strategy must also address the potential endogenity of volatility, and be suitable for a panel that is characterized by $N>T$.

Arellano and Bond (1991) and Blundell and Bond (1998) developed two dynamic panel estimators fitting for such models. They suggest GMM-based estimators in the presence of fixed effects, a lagged dependent variable, potential endogeneity among the regressors, and for panel datasets with a shorter time dimension. These estimators are also particularly useful when the error term exhibits cross-sectional heteroskedasticity. The Arellano-Bond (1991) Difference estimator uses lags of all endogenous variables as instruments for the model in first differences. First-differencing removes the fixed effect, and more importantly, lagged levels of the endogenous variables are uncorrelated with the differenced idiosyncratic error term $\left(\eta_{i t}-\eta_{i t-1}\right)$, thus are valid instruments. In this way, the Arellano-Bond method is able to account for a potential endogeneity problem of the regressors by using lagged levels of the endogenous variables as instruments. The problem with this method, however, is that sometimes lagged levels are poor instruments for variables in first-differences. When data are highly persistent, the Difference GMM estimator performs poorly, as lagged levels give little information about current changes (Roodman, 2006). Thus in the presence 
of persistent data - that is, when $\alpha_{1}$ in equation (2.11) is close to one - Difference GMM suffers from a weak instrument problem.

Blundell and Bond (1998) introduce the System GMM estimator for autoregressive panel models with larger cross-sectional units than time series. The Blundell-Bond approach instruments levels with differences, rather than instrumenting differences with levels as in the Arellano-Bond procedure. It is called a "system" estimator because the procedure involves estimating a system of equations containing both the model in levels and first differences. The main advantage of this approach is that when data are very persistent, past changes may be more relevant to current levels, thereby resulting in stronger instruments (Roodman, 2006). This approach requires that the fixed effect and the idiosyncratic error term satisfy standard properties and must not be correlated. Also the idiosyncratic error term itself must not be serially correlated:

$$
E\left(\gamma_{i}\right)=0, E\left(\eta_{i t}\right)=0, E\left(\gamma_{i} \eta_{i t}\right)=0, E\left(\eta_{i s} \eta_{i t}\right)=0
$$

$$
\text { for all } i=1, \ldots, N ; t=2, \ldots, \mathrm{T} ; \mathrm{t} \neq s
$$

This estimator also relies on the moment condition that the fixed effect be uncorrelated with the first difference of the first observation of the dependent variable.

Note that if countries in the sample respond differently to to time-varying macroeconomic shocks, simple FE or OLS estimation will likely suffer from the problem of heteroskedasticity. The System GMM estimator is advantageous in that there is no restriction placed on the variance of the idiosyncratic error term; there is no requirement for homoskedasticity. Furthermore, estimating the equation in levels allows us to include yearly dummy variables. This is important for the time-wise structural integrity of the model, as it includes periods of exchange rate regime switching and 
financial crises.

\section{Difference and System GMM: Instrument Proliferation}

As Tenreyro (2007) points out, finding exogenous instruments for exchange rate volatility is difficult. The advantage of Difference and System GMM estimators is that instruments are generated internally resulting in an instrument set of lagged levels or differences of the endogenous and predetermined variables. It is important to point out, however, that these GMM estimation procedures generate many instruments. Instrumenting with lags is necessarily related to the size of the time series component of the panel, thus the longer is $T$, the more instruments the process generates. Therefore, there is an inherent instrument proliferation problem.

Instrument proliferation is a problem for a number of reasons. Firstly, it can lead to over-fitting endogenous variables, thereby biasing coefficient estimates of these variables (Roodman, 2009). To account for panel-specific autocorrelation and heteroskedasticity, we employ the two-step (robust covariance matrix) procedure. The presence of a high number of instruments affects this procedure, reducing the efficiency of the GMM estimator. Furthmore. while this does not alter consistency of the coefficient estimates, it does lead to downward-biased standard errors. Finally, standard specification tests for the validity of the instruments are weakened by too many instruments, such as the Hansen J-statistic that tests whether overidentifying restrictions are valid. ${ }^{11}$

Given these potential problems, I pursue three approaches of reducing the instrument count in both the Difference and System GMM estimations, as suggested by Roodman (2009). Left to its own devices, in most statistical packages the Difference and System GMM procedures will generate instruments from all available lags beyond

\footnotetext{
${ }^{11} \mathrm{~A}$ detailed discussion of the problems arising from instrument proliferation can be found in Roodman (2009).
} 
the first period. Thus one way to reduce the instrument count is to limit the number of lags. In this chapter, volatility is the endogenous variable to be instrumented. Therefore, we reduce the instrument count by considering the second lag only for volatility. Note that the first lag of the volatility variable is correlated with the fixed effect, thus the second lag is the appropriate instrument. Using the second lag only is consistent with what we know about exchange rate volatility, as it has been found to show little autocorrelation (Bini-Smaghi, 1991). Thus, lags beyond the second period are unlikely to be relevant. For pre-determined variables like the lagged real exchange rate, we use the first lag only. A second approach to limiting the number of instruments is to collapse them into a single vector, and a third approach is to both limit the number of lags and collapse the instruments into a single vector (Roodman, 2009). All three methods are pursued in this chapter.

\subsection{Empirical Results}

\subsubsection{Panel Unit Root and Cointegration Tests}

Starting with the issue of stationarity, Table 2.4 in the Appendix shows results from the IPS and Hadri LM tests. The first two columns show the $Z_{\tilde{t}-b a r}$ test statistic for the variables in levels and first differences. ${ }^{12}$ Note that the null hypothesis for the IPS test is that all panels contain a unit root. Results from this test suggest that real exports, domestic and world GDP are likely non-stationary, as the test statistics are insignificant. We are able to reject the null hypothesis for all three measures of volatility, suggesting that at least some panels are stationary. Once all variables are first differenced, we are able to reject the null hypothesis of non-stationarity, thus, it appears that exports, domestic, and world GDP follow I(1) processes.

\footnotetext{
${ }^{12}$ Since the panel is unbalanced, we must refer to the $Z_{\tilde{t}-b a r}$ statistic since critical values are not available for the standard $t-b a r$ statistic. The $Z_{\tilde{t}-b a r}$ statistic asymptotically follows a normal distribution and is the standardized version of the $\bar{t}-b a r$.
} 
The Hadri LM $Z$-statistic is reported in the remaining columns of Table 2.4. Note that the null hypothesis is now that all panels are stationary. Results suggest that for all variables except for the Koop volatility measure $\left(V_{3}\right)$, we can reject that all panels are stationary - that is, at least one panel contains a unit root. Upon first-differencing the variables, we see that this induces stationarity among some of the problematic variables, suggesting they follow an I(1) process. However, for first differenced domestic real GDP and the second volatility measure $\left(V_{2}\right)$ we reject the null hypothesis that all panels are stationary. For these variables, some panels contain a unit root even in first differences. It should be noted that these results do not change if we implement the Hadri LM test that accounts for heteroskedasticity.

Both the IPS and Hadri LM tests suggest that real exports, domestic GDP, world GDP, and the real effective exchange rate are non-stationary in levels. The tests differed in their results for real domestic GDP and the second volatility measure in first differences, though real exports, domestic and world GDP were found to be stationary in first differences for both tests, suggesting that they follow an I(1) process. Overall, the first and third volatility measures were found to be stationary in levels. We complete the exercise by determining the extent of a cointegrating relationship between the variables in levels. Table 2.5 in the Appendix presents results from Westerlund's panel cointegration tests (Westerlund and Persyn, 2008) as described in Section 2.3.5. The test was repeated for each volatility measure. We can easily see from the table that we cannot reject the null hypothesis of no cointegration for all test statistics and specifications. That is, there is neither a cointegrating relation for at least one cross-sectional unit, nor the panel as a whole.

Given the relatively short time dimension of the panel, it is not particularly surprising that no cointegrating relationship was found. Existing studies that have found a long-run relationship between exports and volatility have much longer time dimensions in their analysis (and less cross-sectional units). Thus it is likely the time period 
is too short to capture a long-run relationship. Secondly, the unit root tests themselves should be interpreted with caution. Karlsson and Lothgren (2000) show that when the time dimension of the panel is relatively small, tests (such as the IPS test) have low power. Thus, there is a greater risk of incorrectly concluding that an entire panel is non-stationary. Further, as stated previously, the Hadri LM test is best suited for panels with large $T$ and more moderate $N$, which is not the case in this chapter. Results from this test should therefore also be interpreted with caution.

It is likely that a proportion of the panels are non-stationary. Indeed, exports and GDP (domestic or world) are widely known to be naturally trending variables. Individual Dickey Fuller tests suggest that some panels are stationary. In the interest of space, not all results are reported here. ${ }^{13}$ Table 2.6 in the Appendix shows countries that exhibit stationary processes based on Augmented Dickey Fuller tests for the variables in levels. As the table shows, while their proportions are relatively small, exports are stationary for eight of the 72 countries. A total of four countries have stationary domestic GDP measures. Note that for every country, world GDP is nonstationary. The real effective exchange rate is stationary for 13 countries. Many countries have stationary volatility measures - 59 for measure $V_{1}, 41$ for $V_{2}$ and 65 for $V_{3}$.

The preceding discussion pointed to some inconclusiveness in the unit root and cointegration properties of the data used in this chapter. What is clear, however, is that the data are likely to exhibit persistence to some extent. This suggests that the Baltagi and Wu (1999) dynamic FE model and the Difference GMM model described in Section 2.3.3 may not be entirely suitable, thereby further supporting the third estimation technique pursued in this chapter - System GMM. However, the dynamic FE model provides a first look at the empirical relationship between exchange rate volatility and exports.

\footnotetext{
${ }^{13}$ Test results are available upon request from the author.
} 


\subsubsection{Regression Results}

\section{Fixed Effects and Random Effects with AR(1) Errors}

Regression results from the FE and RE models with $\mathrm{AR}(1)$ errors presented in Table 2.7. Both the FE and RE models were estimated for each measure of volatility respectively. Firstly, we can see that Hausman tests confirm the validity of Fixed Effects (over Random Effects) for the second specification of the model only. Note that when $V_{1}$ or $V_{3}$ is used in the regression, the Hausman Chi-squared test statistic is negative, indicating that it did not satisfy the asymptotic properties of the test. This is fairly common in small samples, and Schreiber (2008) suggests taking the absolute value of the test statistic as a practical remedy. Note that this yields very small Chi-square statistics - 0.98 and 2.47 for specifications $I$ and $I I I$ respectively. Based on this approach, we cannot reject the null hypothesis that the differences in $\mathrm{FE}$ and RE parameters are not systematic. Thus while FE and RE are both consistent, the RE estimates are efficient. We can easily see that estimates do not differ significantly between $\mathrm{FE}$ and RE results for these two specifications, so we may discuss the results more generally.

Turning to the variable of interest, we see that for all three measures, exchange rate volatility has a significant and positive impact on exports for the sample. In general, the coefficients on each of the volatility measures are relatively large, with the largest impacts coming from $V_{2}$ (the moving standard deviation). This reflects that the fact that volatility measures themselves are relatively small, thus increasing them by one unit is an implausibly large increase in volatility. For example, for $V_{2}$, a one unit increase in the moving average standard deviation increases exports by over 200 percent. It is therefore more practical to interpret these coefficients in terms of a more meaningful increase in volatility. For the first specification, a one standard deviation increase in exchange rate volatility increases exports by 0.8 percent 
in the FE model, or 0.6 percent in the RE model. ${ }^{14}$ In the second specification we see that a one standard deviation increase in volatility also increases exports but by a larger magnitude - around 5.4 percent according to the FE model. Finally, according to the third specification, a one standard deviation increase in exchange rate volatility increases exports by around one percent in both $F E$ and $R E$ results of the model. The higher magnitude of the impact in from $V_{2}$ is perhaps not surprising, as this measure captures persistence in exchange rate movements rather than higher frequency changes as in $V_{1}$ and $V_{3}$.

In terms of the control variables, we see that domestic and world GDP have positive coefficients as anticipated, though only coefficients on the former are significant for FE and RE estimates. Note that the impact of real GDP is only significant for RE regression results. In terms of J-Curve effects, we would expect a long-run negative impact of the real effective exchange rate on exports, with little or no impact in the short-run. As we see, the contemporaneous REER is positive but insignificant in all specifications of the model, except for the first specification with Random Effects where the coefficient is statistically significant. The lagged REER has a negative impact but is only significant for the first specification of the model when the FE model is estimated. Note that the negative impact of the lagged REER is in line with J-Curve effects - that is, an increase in the REER (an appreciation) should decrease exports in the long-run. The positive current effect of the REER is a puzzling one and not in line with J-Curve effects, but this impact does not have a robust significant impact.

\footnotetext{
${ }^{14}$ This calculation is made by multiplying the estimated coefficient by the standard deviation of the volatility measure and also multiplying by 100 to approximately convert the impact into percentage terms.
} 


\section{Difference GMM}

We now turn to Difference and System GMM regression results from estimating a dynamic panel model. Difference GMM results are presented in Table 2.8 in the Appendix. Reported Difference GMM estimates use the two-step (robust covariance matrix) approach with the Windmeijer (2005) correction for finite sample bias. ${ }^{15}$ Note that to control for the number of lags (as described in the previous section) results are presented based on different instrument sets. More precisely, results are presented using the full instrument set, the collapsed full instrument set, and when only the second lag is used. As before, specifications I, II, and III differ only by the measure of volatility used.

We can see that when all available instruments are used, exports appear to be relatively persistent across all three specifications, with all coefficients exhibiting statistically significant values ranging from around 0.7 when the full instrument set is used, to around 0.9 when we use the second lag only. Domestic GDP has the expected positive signs and is significant across all specifications. Note that the coefficients are all less than one and range between approximately 0.4 and 0.5 , indicating that economic mass has a less than proportionate impact on exports. World GDP has the expected positive sign when the full instrument set is used but is insignificant. When the full instrument set is collapsed, world GDP now has a negative but insignificant impact on exports. Note however that when instruments are restricted to the second lag only, this negative impact is statistically significant and somewhat puzzling. The REER is found to have a negative impact across all specifications and instrument sets, though is only statistically significant for when V1 is used and the full instrument set is collapsed. The lagged REER largely has a positive impact across the specifications and instrument sets, but again this impact is only significant when $V_{1}$

\footnotetext{
${ }^{15}$ The two-step procedure ensures consistency of standard error estimates in the presence of heteroskedasticity and autocorrelation and the Windmeijer (2005) finite-sample correction adjusts for the downward bias typically present in these robust standard errors.
} 
is used to measure volatility and the full instrument set is collapsed. These signs do not support the $\mathrm{J}$-curve hypothesis.

In terms of exchange rate volatility impacts, the first and third volatility measures show a negative impact on exports, while the second measure shows a positive one. For the latter, none of these coefficients are statistically different from zero. The negative impact of exchange rate volatility on exports holds for when $V_{1}$ and $V_{3}$ are used as volatility measures and the instruments are collapsed or restricted to the second lag. The magnitude of these impacts are less severe when the smallest instrument set is used. For example, for the third measure of volatility (the Koop construction), a one standard deviation increase in volatility reduces exports by around 1 percent.

The p-value from the $\mathrm{AR}(2)$ test indicates that there is no second-order serial correlation across all specifications and instrument sets. When the full instrument set is used, note that the Hansen test for overidentifying restrictions has a perfect p-value of 1.000. Taken on its own, this suggests that the instruments as a group are exogenous. However, combined with an instrument count of 411 and a group count of 72 , these results are likely suffering from the instrument proliferation problem discussed earlier. Thus, the Hansen test, while robust to heteroskedasticity, appears to be weakened by the number of instruments. When the instrument set is reduced, the number of instruments (51) is now less than the number of groups (72), and we have more reasonable yet troubling p-values for the Hansen J statistic. These statistics drop significantly when the number of instruments are reduced, indicating that instrument proliferation was a problem. More importantly, these p-values indicate significance or close-to-significance at the 10 percent level for the Hansen test, suggesting that instruments in the Difference GMM regressions are weak.

Recall that persistent data can lead to a problem of weak instruments in Difference GMM. Thus, it is entirely possible that levels serve as poor instruments for first differences in this case, as exports appear to be very persistent. Past changes are 
more likely to be better determinants of current changes in volatility, for example. This further substantiates the use of System GMM.

\subsubsection{System GMM}

System GMM results are presented in Table 2.9. As with the Difference GMM procedure, System GMM estimates are obtained using the two-step approach for robust standard errors with the Windmeijer (2005) correction for finite sample bias. As before, coefficient estimates are presented not only using the full instrument set but also for reduced instrument sets. Results are also reported for all three measures of volatility. Note that year dummy variables were included in these regressions so as to ensure the structural stability of the time series. That is, until now we have not been able to account for structural changes in our dataset, either arising from exchange rate regime changes, financial crises, and/or policy-induced exchange rate changes for example. Introducing yearly dummy variables is a way to account for such shifts.

We see that across all specifications and instrument sets, exports found to be highly persistent, with a coefficient above 0.9 . While domestic GDP has the expected positive sign, it is only significant when we use the second lag only as instruments and we use either the first or second measure of volatility. In general, these coefficient estimates are relatively small, indicating a smaller impact of a country's economic size on its exports than in the Difference GMM results. World GDP in general has a negative impact on exports, though these impacts are not statistically different from zero. The contemporaneous REER appears to have a negative impact but this is only significant in the last instrument reduction when the second measure of volatility is used. The lagged REER coefficients vacillate between positive and negative values across the specifications. We see that when instruments are restricted to the second lag only and collapsed into a single vector, the lagged REER has a positive impact, 
which is only significant when $V_{2}$ is used to measure volatility.

Exchange rate volatility overall appears to have a significant and negative impact on exports. The most robust result is achieved when $V_{3}$ is used to measure volatility. For this measure, a negative and significant impact of volatility on exports persists with reductions in the instrument count. In the last instrument count reduction, a one standard deviation increase in $V_{3}$ reduces exports by almost 6 percent. This is in line with with results from other authors (see Chit et al. (2008) or Tenreyro (2007), for example).

Turning to volatility measures $V_{1}$ and $V_{2}$, we see that the former has a negative impact for all instrument counts, though the coefficient loses its significance in the last instrument count reduction. While $V_{2}$ has a statistically significant impact on exports for when the full instrument set is used or when instruments are confined to the second lag only, when the number of instruments is reduced to 26 , there is a positive statistically significant impact of $V_{2}$ on exports.

The Arellano-Bond test for $\mathrm{AR}(2)$ errors suggests that there is no second order serial correlation in any of the specifications. When the full instrument set is used there are 476 instruments in total, while when the second lag only is used the instrument count is reduced to 116 . In both cases we see that the p-value for the Hansen J statistic is either one or close to one. This combined with the high instrument counts suggest that instrument proliferation is a problem in these two cases, and so results from these regressions should be interpreted with care. In the case where instruments are reduced to 26 , we see more reasonable p-values and they suggest that the overidentifying restrictions are valid. Thus, instruments in the System GMM regressions are stronger in this case, compared to the Difference GMM results we saw earlier. 


\subsection{Extension: Low Income Countries}

The preceding analysis has found an overall negative impact of exchange rate volatility for a sample of 72 developing and emerging market economies. A question of interest, however, is to ascertain whether this result is robust to restricting the sample to low- and lower-middle-income countries. That is, we want to determine whether the negative impact of exchange rate volatility holds for poorer countries. This is particularly interesting from a development perspective, as these countries are more likely to have less-developed financial markets and therefore fewer opportunities to hedge exchange rate risk. Thus, Difference and System GMM results are repeated for the poorer countries in the overall sample. These results are presented in Table 2.10 in the Appendix. ${ }^{16}$

Focusing on the impact of exchange rate volatility, we see that $V_{1}$ and $V_{3}$ have significant negative impacts on exports for Difference and System GMM results respectively. The magnitude of the impact is similar to previous results. We see that for a one standard deviation increase in $V_{1}$, the associated reduction in exports according to Difference GMM results is around 0.6 percent, while exports decrease by around one percent for a one standard deviation increase in $V_{3}$. We can see that exports across all three specifications of the Difference GMM model are very persistent, so System GMM results are likely to be better estimates. For the System GMM results, we see that a one standard deviation increase in $V_{1}$ reduces exports by around 2 percent, while an increase in $V_{3}$ by one standard deviation reduces exports by 6 percent as we saw previously. We also see that in this restricted sample, the positive impact of $V_{2}$ persists. Overall, however, there appears to be a negative impact of exchange

\footnotetext{
${ }^{16}$ Low and lower-middle-income countries were determined according to the World Bank's classification of counties by per capita income. This leaves us with 61 countries from the original sample. Results are only presented for reduced instrument counts. Note that we cannot compare these results to the higher income countries as there are only 11, and Difference and System GMM are not suitable to a panel with $N<T$.
} 
rate volatility on exports for the poorer countries in the sample.

\subsection{Conclusions}

The goal of this chapter has been to estimate the impact of exchange rate volatility on real exports in developing countries and emerging markets. In summary, System GMM appears to be the superior approach in analyzing this question, as it takes into account the dynamic nature of the model, the potential endogeneity of volatility in the exports-volatility relationship, the possibility of country-specific effects, and the relatively persistent behaviour of exports. This method has been little used in the literature to date. Results point to an overall negative impact of exchange rate volatility in exports, with the largest robust impact found for the new measure of volatility, $V_{3}$. Using the Koop construction, we found this deterring impact on exports to be approximately 6 percent for a one standard deviation increase in volatility. A negative impact of the first measure of volatility (the standard deviation of the first differences of the REER) was also found, though this impact was not robust to the last specification of the System GMM model. However, when restricted to lower income countries, both $V_{1}$ and $V_{3}$ had robust statistically significant negative impacts on exports. These results suggest that developing and emerging market economies wishing to promote exports may be able to do so by also supporting exchange rate stability with major currencies, particularly for poorer countries.

The second measure of volatility (the moving average standard deviation, $V_{2}$ ) had very inconsistent results, lacking any robust impact of exchange rate volatility on exports. As mentioned previously, exchange rates show little autocorrelation, and so the moving average standard deviation assumes too much persistence in exchange rate movements and actually distorts volatility. Thus also instrumenting such a measure with its lags (such as in the Difference or System GMM approaches) further distorts 
volatility. Other results also point to some inconclusiveness on the existence of $\mathrm{J}$ Curve effects. However, this is not an uncommon result for countries in our sample Rose (1990) found no evidence of J-Curve effects for a sample of developing countries. Also, relative price variables in general do not have robust impacts in the existing literature (see for example Chit et al., 2008 or Todani and Munyama, 2005). Note that this is likely due to the use of consumer price indices in the construction of the real effective exchange rate. Aggregate price indices such as the CPI are poor proxies for the relative price of export goods. Improvements in this area, however, would require that data for export good prices be more widely available.

\section{References}

Arellano, M. and S. Bond (1991), "Some tests of specification for panel data: Monte carlo evidence and an application to employment equations." Review of Economic Studies, 58, 277-97.

Aristotelous, K. (2001), "Exchange-rate volatility, exchange-rate regime, and trade volume: evidence from the uk-us export function (1889-1999)." Economics Letters, $72,87-94$.

Arize, A. (1996), "The impact of exchange rate uncertainty on export growth: evidence from Korean data." International Economic Journal, 10, 49-60.

Arize, A. (2008), "Exchange rate volatility in Latin America and its impact on foreign trade." International review of economics and finance, 17, 33-44.

Arize, A., J. Malindretos, and K. Kasibhatla (2003), "Exchange rate volatility in Latin America: the case of 13 LDCs." International Advances in Economic Research, 9, 33-44. 
Baak, S.J, M. A. Al-Mahmood, and S. Vixathep (2007), "Exchange rate volatility and exports from east asian countries to japan and the usa." Applied Economics, $39,947-959$.

Bahmani-Oskooee, M. (1991), "exchange rate uncertainty and trade flows of developing countries." Journal of Developing Areas, 25, 497-598.

Bahmani-Oskooee, M. and S. Hegerty (2009), "The effects of exchange-rate volatility on commodity trade between the united states and mexico." Southern Economic Journal, 75, 1019-1044.

Bahmani-Oskooee, M. and N. Ltaifa (1992), "Effects of exchange rate risk on exports: crosscountry analysis." World Development, 20, 1173-1181.

Bahmani-Oskooee, M. and Y. Wang (2007), "The impact of exchange rate volatility on commodity trade between the u.s. and china." Economic Issues Journal Articles, $12,31-52$.

Bailey, M., G. Tavlas, and M. Ulan (1987), "The impact of exchange-rate volatility on export growth: Some theoretical considerations and empirical results." Journal of Policy Modeling, 9, 225-243.

Baltagi, B. and P. Wu (1999), "Unequally spaced panel data with AR(1) disturbances." Econometric Theory, 15.

Bénassy-Quéré, A. and A. Lahrèche-Revil (2003), "Trade linkages and exchange rates in Asia: The role of China." Working Papers 2003-21, CEPII research center.

Bhagwati, J. (2007), In Defense of Globalization:With a New Afterword. Oxford University Press, USA.

Bini-Smaghi, L. (1991), "exchange raet volatility and trade: why is it so difficult to find any empirical relationship?" Applied Economics, 23, 927-936. 
Bleaney, M. and M. Francisco (2007), "The performance of exchange rate regimes in developing countries - does the classifications scheme matter?" Technical Report 07/04, University of Nottingham, CREDIT.

Blundell, R. and S. Bond (1998), "Initial conditions and moment restrictions in dynamic panel data models." Journal of Econometrics, 87, 115-143.

Bonroy, O., J.-P. Gervais, and B. Larue (2007), "Are exports a monotonic function of exchange rate volatility? evidence from disaggregated pork exports." Canadian Journal of Economics, 40, 127-154.

Boothe, P. and D. Glassman (1987), "The statistical distribution of exchange rates: Empirical evidence and economic implications." Journal of International Economics, 22, 297-319.

Brada, J. C and J. Mendez (1988), "Exchange rate risk, exchange rate regime and the volume of international trade." Kyklos, 41, 263-80.

Broll, U. and B. Eckwert (1999), "Exchange rate volatility and international trade." Southern economic journal, 66.

Caves, R., J. Frankel, and R. Jones (2002), World Trade and Payments: An Introduction, 9th Edition. Addison-Wesley.

Chit, M. (2008), "Exchange rate volatility and exports: evidence from the asean-china free trade area." Journal of Chinese Economic and Business Studies, 6, 261-277.

Chit, M., M. Rizov, and D. Willenbockel (2008), "Exchange rate volatility and exports: New empirical evidence from the emerging east asian economies." MPRA Paper 9014, University Library of Munich, Germany.

Chou, W. (2000), "Exchange rate variability and china's exports." Journal of Comparative Economics, 28, 61-79. 
Chowdhury, A. (1993), "Does exchange rate volatility depress trade flows? evidence from error-correction models." The Review of Economics and Statistics, 75, 700706.

Clark, P., S.-J. Wei, N. Tamirisa, A. Sadikov, and L. Zeng (2004), "A new look at exchange rate volatility and trade flows." IMF Occasional Papers 235, International Monetary Fund.

Cushman, D. (1983), "The effects of real exchange rate risk on international trade." Journal of International Economics, 15, 45-63.

De Grauwe, P. (1988), "Exchange rate variability and the slowdown in growth of international trade." IMF Staff Papers, 35, 63-84.

Dell'Ariccia, G. (1999), "Exchange rate fluctuations and trade flows: Evidence from the european union." IMF Staff Papers, 46, 315-335.

Dellas, H. and B.-Z, Zilberfarb (1993), "Real exchange rate volatility and internaitonal trade: a reexamination of the theory." Southern economic joumal, 59, 641-47.

Dixit, A. (1989), "Entry and exit decisions under uncertainty." Journal of Political Economy, 97, 620-38.

Doroodian, K. (1999), "Does exchange rate volatility deter international trade in developing countries?" Journal of Asian Economics, 10, 465-474.

Doğanlar, M. (2002), "Estimating the impact of exchange rate volatility on exports: evidence from asian countries." Applied Economics Letters, 9, 859-863.

Easterly, W., R. Islam, and J. Stiglitz (2000), "Shaken and stirred: Explaining growth volatility." 
Egert, B. and A. Morales-Zumaquero (2008), "Exchange rate regimes, foreign exchange volatility, and export performance in central and eastern europe: Just another blur project?" Review of Development Economics, 12, 577-593.

Eichengreen, B. and D. Irwin (1996), The Role of History in Bilateral Trade Flows. University of Chicago Press.

Ethier, W. (1973), "International trade and the forward exchange market." American Economic Review, 63, 494-503.

Franke, G. (1991), "Exchange rate volatility and international trading strategy." Journal of International Money and Finance, 10, 292-307.

Glick, R. and A. Rose (2002), "Does a currency union affect trade? the time-series evidence." European Economic Review, 46, 1125-1151.

Hadri, K. (2000), "Testing for stationarity in heterogeneous panel data." Econometrics Journal, 3, 148-161.

Havemann, R. and C. Kularatne (2008), "Why are some exchange rates more volatile than others? Evidence from transition economies."

Hondroyiannis, G., P. Swamy, G. Tavlas, and M. Ulan (2008), "Some further evidence on exchange-rate volatility and exports." Review of World Economics (Weltwirtschaftliches Archiv), 144, 151-180.

Hooper, P. and S. Kohlhagen (1978), "The effect of exchange rate uncertainty on the prices and volume of international trade." Journal of International Economics, 8, 483-511.

Im, K. S., M. H. Pesaran, and Y. Shin (2003), "Testing for unit roots in heterogeneous panels." Journal of Econometrics, 115, 53-74. 
Karlsson, S. and M. Lothgren (2000), "On the power and interpretation of panel unit root tests." Economics Letters, 66, 249-255.

Kenen, P. and D. Rodrik (1986), "Measuring and analyzing the effects of short-term volatility in real exchange rates." The Review of Economics and Statistics, 68, $311-15$.

Koop, G. (2006), Analysis of financial data. John Wiley \& Sons Inc.

Koray, F. and W. Lastrapes (1989), "Real exchange rate volatility and u.s. bilateral trade: A var approach." The Review of Economics and Statistics, 71, 708-12.

Kumar, R. and R. Dhawan (1991), "Exchange rate volatility and pakistan's exports to the developed world, 1974-85." World Development, 19, 1225-1240.

Levy-Yeyati, E. and F. Sturzenegger (2003), "To float or to fix: Evidence on the impact of exchange rate regimes on growth." American Economic Review, 93, 11731193.

Levy-Yeyati, E. and F. Sturzenegger (2005), "Classifying exchange rate regimes: Deeds vs. words." European Economic Review, 49, 1603-1635.

McKenzie, M. (1999), "The impact of exchange rate volatility on international trade flows." Journal of Economic Surveys, 13, 71-106.

Medhora, R. (1990), "The effect of exchange rate variability on trade: The case of the west african monetary union's imports." World Development, 18, 313-324.

Omojimite, B. and G. Akpokodje (2010), "A comparative analysis of the effect of exchange rate volatility on exports in the CFA and non-CFA countries of Africa." Journal of Social Sciences, 24, 23-31. 
Pedroni, P. (2004), "Panel cointegration: Asymptotic and finite sample properties of pooled time series tests with an application to the ppp hypothesis." Econometric Theory, 20, 597-625.

Persyn, D. and J. Westerlund (2008), "Error-correctionbased cointegration tests for panel data." Stata Journal, 8, 232-241.

Poon, W.-C., C.-K. Choong, and M. Habibullah (2005), "Exchange rate volatility and exports for selected East Asian countries: Evidence from error-correction models." ASEAN Economic Bulletin, 22, 144-159.

Qian, Y. and P. Varangis (1994), "Does exchange rate volatility hinder export growth: additional evidence." Empirical Economics, 19, 376-396.

Roodman, D. (2009a), "How to do xtabond2: An introduction to difference and system gmm in stata." Stata Journal, 9, 86-136.

Roodman, D. (2009b), "A note on the theme of too many instruments." Oxford Bulletin of Economics and Statistics, 71, 135-158.

Rose, A. (1990), "Exchange rates and the trade balance : Some evidence from developing countries." Economics Letters, 34, 271-275.

Rose, A. (2000), "One money, one market: the effect of common currencies on trade." Economic Policy, 15, 7-46.

Rose, A. (2002), "Honey, the currency union effect on trade hasn't blown up." The World Economy, 25, 475-479.

Rose, A. and T. Stanley (2005), "A meta-analysis of the effect of common currencies on international trade." Journal of Economic Surveys, 19, 347-365. 
Sauer, C. and A. Bohara (2001), "Exchange rate volatility and exports: Regional differences between developing and industrialized countries." Review of International Economics, 9, 133-52.

Schreiber, S. (2008), "The hausman test statistic can be negative even asymptotically." Journal of Economics and Statistics, 228, 394-405.

Sercu, P. (1992), "Exchange risk, exposure, and the option to trade." Journal of International Money and Finance, 11, 579-593.

Sercu, P. and C. Vanhulle (1992), "Exchange rate volatility, international trade, and the value of exporting firms." Journal of Banking \& Finance, 16, 155-182.

Siregar, R. and R. Rajan (2004), "Impact of exchange rate volatility on indonesia's trade performance in the 1990s." Journal of the Japanese and International Economies, 18, 218-240.

The World Bank (2010), World Development Indicators. Washington, DC.

Thursby, J. and M. Thursby (1987), "Bilateral trade flows, the linder hypothesis, and exchange risk." The Review of Economics and Statistics, 69, 488-95.

Todani, K. and V. Munyama (2005), "Exchange rate volatility and exports to South Africa." South African Reserve Bank.

van Wincoop, E. and P. Bacchetta (2000), "Does exchange-rate stability increase trade and welfare?" American Economic Review, 90, 1093-1109.

Vergil, H. (2002), "Exchange rate volatility in Turkey and its effect on trade flows." Journal of Economic and Social Research, 4, 83-99.

Westerlund, J. (2007), "Testing for error correction in panel data." Oxford Bulletin of Economics and Statistics, 69, 709-748. 
Willett, T. (1986), "Exchange-rate volatility, international trade, and resource allocation: A perspective on recent research." Journal of International Money and Finance, 5, S101-S112.

Windmeijer, F. (2005), "A finite sample correction for the variance of linear efficient two-step gmm estimators." Journal of Econometrics, 126, 25-51. 


\subsection{Appendix}

Table 2.1: List of Countries

\begin{tabular}{cccc}
\hline \hline Algeria & Czech Republic & Lesotho & Samoa \\
Antigua and Barbuda & Dominica & Macedonia & Sierra Leone \\
Argentina & Dominican Republic & Malawi & Solomon Islands \\
Armenia & Ecuador & Malaysia & South Africa \\
Belize & Egypt & Malta & St. Kitts and Nevis \\
Bolivia & Equatorial Guinea & Mexico & St. Lucia \\
Brazil & Fiji & Moldova & St. Vincent and the Grenadines \\
Bulgaria & Gabon & Morocco & Thailand \\
Burundi & Gambia & Nicaragua & Togo \\
Cameroon & Georgia & Nigeria & Tonga \\
Central African Rep. & Ghana & Pakistan & Trinidad and Tobago \\
Chile & Grenada & Papua New Guinea & Tunisia \\
China & Guyana & Paraguay & Turkey \\
Colombia & Hungary & Peru & Uganda \\
Congo, Dem. Rep. & India & Philippines & Ukraine \\
Costa Rica & Indonesia & Poland & Uruguay \\
Cote d'Ivoire & Iran & Romania & Venezuela \\
Croatia & Kiribati & Russia & Zambia \\
\hline \hline
\end{tabular}


Table 2.2: Real Effective Exchange Rate Volatility by Exchange Rate Regime

\begin{tabular}{lccc}
\hline \hline Country Groups & $V_{1}$ & $V_{2}$ & $V_{3}$ \\
\hline Overall (1991-2008) & 0.027 & 0.008 & 0.016 \\
& $(0.014)$ & $(0.020)$ & $(0.111)$ \\
\hline Floating (1991-2004) & 0.033 & 0.010 & 0.023 \\
& $(0.045)$ & $(0.015)$ & $(0.104)$ \\
Fixed (1991-2004) & 0.019 & 0.006 & 0.006 \\
& $(0.022)$ & $(0.007)$ & $(0.048)$ \\
\hline \hline
\end{tabular}

Note: Standard deviations are in parentheses. $V_{1}, V_{2}$, and $V_{3}$ correspond to the three volatility measures described in Section 3 of the paper (see text for precise definitions). "Floating" refers to years in the sample where countries adhered to a De Facto intermediate or floating exchange rate regime and "Fixed" refers to a pure fixed exchange rate regime (Levy-Yeyati and Sturzenegger, 2005). Countries in the sample for Floating and Fixed include all in Table 1 except for Malta and Morocco. Data availability limits these sub-samples to cover 1991-2004 as opposed to 1991-2008 in the overall sample.

Table 2.3: Summary Statistics, 1991-2008

\begin{tabular}{lcccc}
\hline \hline Variable & Mean & Standard Deviation & Minimum & Maximum \\
\hline Real exports & 8.07 & 2.39 & 1.01 & 13.90 \\
Domestic real GDP & 22.96 & 2.39 & 16.90 & 28.49 \\
World real GDP & 30.98 & 0.16 & 30.72 & 31.25 \\
Real effective exchange rate & 4.63 & 0.22 & 2.97 & 5.97 \\
\hline \hline
\end{tabular}

Note: All variables are measured in natural logarithms. Exports, domestic and world GDP are measured in 1990 U.S. dollars. 
Table 2.4: Panel Unit Root Tests

\begin{tabular}{lcccc}
\hline \hline Variable & \multicolumn{2}{c}{ Im, Pesaran and Shin Test } & \multicolumn{2}{c}{ Hadri LM Test } \\
\hline \multirow{3}{*}{ Real exports } & Levels & First Differences & Levels & First Differences \\
\cline { 2 - 5 } & 3.285 & $-15.718^{* * *}$ & $52.932^{* * *}$ & -1.293 \\
\multirow{2}{*}{ Domestic real GDP } & $(1.000)$ & $(0.000)$ & $(0.000)$ & $(0.902)$ \\
& 15.768 & $-11.905^{* * *}$ & $59.598^{* * *}$ & $11.167^{* * *}$ \\
World real GDP & $(1.000)$ & $(0.000)$ & $(0.000)$ & $(0.000)$ \\
& 28.904 & $-12.838^{* * *}$ & $63.907^{* * *}$ & 1.026 \\
Real effective exchange rate & $(1.000)$ & $(0.000)$ & $(0.000)$ & $(0.153)$ \\
& -0.646 & $-14.631^{* * *}$ & $31.798^{* * *}$ & -0.969 \\
$V_{1}$ & $(0.259)$ & $(0.000)$ & $(0.000)$ & $(0.834)$ \\
& $-14.141^{* * *}$ & $-20.020^{* * *}$ & $6.919^{* * *}$ & -3.317 \\
$V_{2}$ & $(0.000)$ & $(0.000)$ & $(0.000)$ & $(1.000)$ \\
& $-10.588^{* * *}$ & $-17.374^{* * *}$ & $11.648^{* * *}$ & $1.6391^{*}$ \\
$V_{3}$ & $(0.000)$ & $(0.000)$ & $(0.000)$ & $(0.051)$ \\
& $-15.307^{* * *}$ & $-21.045^{* * *}$ & -0.772 & -5.773 \\
\hline \hline
\end{tabular}

Note: The IPS has as null hypothesis that all panels contain unit root while the Hadri LM test has the null that all panels are stationary. Reported test statistics correspond to the $Z_{\tilde{t}-b a r}$ statistic in the IPS test and the $Z$ statistic for the Hadri LM test. All $p$-values are in parentheses. ${ }^{* * *}$ indicates significance at the one percent level and * indicates significance at the ten percent level. Note that for the Hadri LM test, the sample is restricted to the 1993-2008 time period for variables in levels and 1994-2008 for variables in differences. The IPS test covers the entire 1991-2008 period. 
Table 2.5: Panel Cointegration Tests

\begin{tabular}{lccc}
\hline \hline Statistic & \multicolumn{3}{c}{ Specification } \\
\hline \multirow{4}{*}{$G_{\tau}$} & I & II & II \\
& -2.238 & -2.312 & -2.272 \\
\multirow{4}{*}{$G_{\alpha}$} & $(0.967)$ & $(0.881)$ & $(0.938)$ \\
& -3.923 & -3.478 & -3.435 \\
$P_{\tau}$ & $(1.000)$ & $(1.000)$ & $(1.000)$ \\
& -15.827 & -18.658 & -14.310 \\
$P_{\alpha}$ & $(0.987)$ & $(0.348)$ & $(1.000)$ \\
& -3.459 & -3.318 & -3.389 \\
& $(1.000)$ & $(1.000)$ & $(1.000)$ \\
\hline \hline
\end{tabular}

Note: Specifications $I, I I$, and $I I I$ include $V_{1}, V_{2}$, and $V_{3}$ respectively. Test statistics correspond to Westerlund's (2007) panel cointegration test. All $p$-values are in parentheses. The null hypothesis is no cointegration.

Table 2.6: Individual Dickey Fuller Tests

\begin{tabular}{lc}
\hline \hline Variable & Number of Stationary Countries \\
\hline Real exports & 8 \\
Real domestic GDP & 4 \\
Real world GDP & 0 \\
Real effective exchange rate & 13 \\
$V_{1}$ & 59 \\
$V_{2}$ & 41 \\
$V_{3}$ & 65 \\
\hline \hline
\end{tabular}

Note: These results are based on individual (Augmented) Dickey Fuller tests that have as null hypothesis that a variable contains a unit root (level non-stationarity). 
Table 2.7: Fixed Effects and Random Effects with AR(1) Errors, 1991-2008

\begin{tabular}{|c|c|c|c|c|c|c|}
\hline \multirow[t]{3}{*}{ Variable } & \multicolumn{6}{|c|}{ Dependent variable: Real exports } \\
\hline & \multicolumn{2}{|c|}{$I$} & \multicolumn{2}{|c|}{$I I$} & \multicolumn{2}{|c|}{$I I I$} \\
\hline & $\mathrm{FE}$ & $\mathrm{RE}$ & $\mathrm{FE}$ & $\mathrm{RE}$ & FE & $\mathrm{RE}$ \\
\hline \multirow[t]{2}{*}{ Real domestic GDP } & $1.162^{* * *}$ & $1.003^{* * *}$ & $1.156^{* * *}$ & $1.006^{* * *}$ & $1.148^{* * *}$ & $1.002^{* * *}$ \\
\hline & $(0.000)$ & $(0.000)$ & $(0.000)$ & $(0.000)$ & $(0.000)$ & $(0.000)$ \\
\hline \multirow[t]{2}{*}{ Real world GDP } & 0.132 & $0.582^{* * * *}$ & 0.150 & $0.590^{* * *}$ & 0.161 & $0.576^{* * *}$ \\
\hline & $(0.420)$ & $(0.000)$ & $(0.356)$ & $(0.000)$ & $(0.325)$ & $(0.000)$ \\
\hline \multirow[t]{2}{*}{ Real effective exchange rate } & 0.067 & $0.096^{* *}$ & 0.015 & 0.059 & 0.029 & 0.052 \\
\hline & $(0.140)$ & $(0.039)$ & $(0.733)$ & $(0.149)$ & $(0.510)$ & $(0.217)$ \\
\hline \multirow[t]{2}{*}{ Real effective exchange rate $(t-1)$} & $-0.092^{* *}$ & -0.063 & -0.037 & -0.016 & -0.061 & -0.030 \\
\hline & $(0.042)$ & $(0.143)$ & $(0.366)$ & $(0.679)$ & $(0.169)$ & $(0.472)$ \\
\hline \multirow[t]{2}{*}{$V_{1}$} & $0.597^{* * *}$ & $0.467^{* * *}$ &.. &.. &.. &.. \\
\hline & $(0.000)$ & $(0.000)$ & & & & \\
\hline \multirow[t]{2}{*}{$V_{2}$} &.. & .. & $2.722^{* * *}$ & $2.587^{* * *}$ & .. & .. \\
\hline & & & $(0.000)$ & $(0.000)$ & & \\
\hline \multirow[t]{2}{*}{$V_{3}$} & .. & .. & .. & .. & $1.182^{* * *}$ & $0.086^{*}$ \\
\hline & & & & & $(0.003)$ & $(0.060)$ \\
\hline$\hat{\rho}$ & 0.765 & 0.765 & 0.764 & 0.764 & 0.764 & 0.763 \\
\hline \multicolumn{7}{|l|}{ Test statistics ( $p$-values): } \\
\hline$F /$ Wald -statistic & $(0.000)$ & $(0.000)$ & $(0.000)$ & $(0.000)$ & $(0.000)$ & $(0.000)$ \\
\hline$F$-statistic $\mu_{i}=0$ & $(0.000)$ & & $(0.000)$ & & $(0.000)$ & \\
\hline Hausman test & \multicolumn{2}{|c|}{$(\mathrm{n} / \mathrm{a})^{a}$} & \multicolumn{2}{|c|}{$(0.009)$} & \multicolumn{2}{|c|}{$(\mathrm{n} / \mathrm{a})^{b}$} \\
\hline$R^{2}$ Overall & 0.93 & 0.93 & 0.93 & 0.93 & 0.93 & 0.93 \\
\hline$R^{2}$ Within & 0.28 & 0.72 & 0.29 & 0.73 & 0.28 & 0.72 \\
\hline Observations & 1209 & 1209 & 1209 & 1209 & 1209 & 1209 \\
\hline
\end{tabular}

${ }^{a}{ }^{b}$ Correspond to negative $\chi^{2}$ test statistics -0.98 and -2.47 respectively.

Note: All $p$-values are in parentheses. ${ }^{* * *}$ and ${ }^{* *}$ denote significance at the one percent and five percent level respectively. Real exports, domestic, and world GDP are all measured in 1991 U.S. dollars. All variables except volatility are measured in natural logarithms. Specifications $I, I I$, and $I I I$ include volatility measures $V_{1}, V_{2}$, and $V_{3}$ respectively. See text for precise definitions. The value $\hat{\rho}$ is the estimate of the autoregressive parameter on the idiosyncratic error term. $R^{2}$ Within refers to the goodness of fit once observations have been de-meaned. 
Table 2.8: Coefficient Estimates: Difference GMM, 1991-2008

\begin{tabular}{|c|c|c|c|c|c|c|c|c|c|}
\hline \multirow{2}{*}{$\begin{array}{l}\text { Variable } \\
\text { Dependent variable: Real exports }\end{array}$} & \multicolumn{3}{|c|}{ Full Instrument Set } & \multicolumn{3}{|c|}{ Full Instrument Set, Collapsed } & \multicolumn{3}{|c|}{ Second Lag Only } \\
\hline & $I$ & $I I$ & $I I I$ & $I$ & $I I$ & $I I I$ & $I$ & $I I$ & $I I I$ \\
\hline $\begin{array}{l}\text { Real exports }(t-1) \\
(0.000)\end{array}$ & $\begin{array}{c}0.703^{* * *} \\
(0.000)\end{array}$ & $\begin{array}{c}0.6888^{* * *} \\
(0.000)\end{array}$ & $\begin{array}{l}0.699^{* * *} \\
(0.000)\end{array}$ & $\begin{array}{l}0.858^{* * *} \\
(0.000)\end{array}$ & $\begin{array}{l}0.777^{* * *} \\
(0.000)\end{array}$ & $\begin{array}{l}0.862^{* * *} \\
(0.000)\end{array}$ & $\begin{array}{l}0.913^{* * *} \\
(0.000)\end{array}$ & $\begin{array}{l}0.879^{* * *} \\
(0.000)\end{array}$ & $0.918^{* * *}$ \\
\hline Domestic real GDP & $\begin{array}{c}0.399^{* * *} \\
(0.000)\end{array}$ & $\begin{array}{l}0.417^{* * *} \\
(0.000)\end{array}$ & $\begin{array}{l}0.410^{* * *} \\
(0.000)\end{array}$ & $\begin{array}{l}0.393^{* * *} \\
(0.009)\end{array}$ & $\begin{array}{c}0.487^{* * *} \\
(0.000)\end{array}$ & $\begin{array}{l}0.422^{* * *} \\
(0.004)\end{array}$ & $\begin{array}{l}0.455^{* * *} \\
(0.001)\end{array}$ & $\begin{array}{c}0.478^{* * *} \\
(0.000)\end{array}$ & $\begin{array}{l}0.440^{* * *} \\
(0.002)\end{array}$ \\
\hline World real GDP & $\begin{array}{c}0.041 \\
(0.725)\end{array}$ & $\begin{array}{c}0.030 \\
(0.813)\end{array}$ & $\begin{array}{c}0.032 \\
(0.794)\end{array}$ & $\begin{array}{l}-0.266 \\
(0.141)\end{array}$ & $\begin{array}{l}-0.199 \\
(0.320)\end{array}$ & $\begin{array}{l}-0.295 \\
(0.137)\end{array}$ & $\begin{array}{l}-0.417^{* *} \\
(0.033)\end{array}$ & $\begin{array}{l}-0.383^{* *} \\
(0.050)\end{array}$ & $\begin{array}{l}-0.395^{*} \\
(0.058)\end{array}$ \\
\hline Real effective exchange rate & $\begin{array}{l}-0.017 \\
(0.892)\end{array}$ & $\begin{array}{l}-0.003 \\
(0.981)\end{array}$ & $\begin{array}{l}-0.019 \\
(0.873)\end{array}$ & $\begin{array}{l}-0.244^{*} \\
(0.054)\end{array}$ & $\begin{array}{l}-0.108 \\
(0.306)\end{array}$ & $\begin{array}{l}-0.166 \\
(0.188)\end{array}$ & $\begin{array}{c}-0.187 \\
(0.107)\end{array}$ & $\begin{array}{l}-0.076 \\
(0.414)\end{array}$ & $\begin{array}{l}-0.145 \\
(0.177)\end{array}$ \\
\hline Real effective exchange rate ( $t-1)$ & $\begin{array}{c}0.198 \\
(0.254)\end{array}$ & $\begin{array}{c}0.069 \\
(0.433)\end{array}$ & $\begin{array}{c}0.113 \\
(0.231)\end{array}$ & $\begin{array}{c}0.173^{*} \\
(0.083)\end{array}$ & $\begin{array}{c}0.193 \\
(0.193)\end{array}$ & $\begin{array}{c}0.140 \\
(0.270)\end{array}$ & $\begin{array}{c}0.103 \\
(0.301)\end{array}$ & $\begin{array}{c}-0.023 \\
(0.820)\end{array}$ & $\begin{array}{c}0.068 \\
(0.527)\end{array}$ \\
\hline$V_{1}$ & $\begin{array}{c}-0.208 \\
(0.379)\end{array}$ &.. &. & $\begin{array}{c}-1.412^{* * *} \\
(0.000)\end{array}$ &.. &.. & $\begin{array}{c}-0.570^{* * *} \\
(0.009)\end{array}$ &.. &.. \\
\hline$V_{2}$ & .. & $\begin{array}{c}0.389 \\
(0.668)\end{array}$ & .. &. & $\begin{array}{c}-0.368 \\
(0.804)\end{array}$ &. & .. & $\begin{array}{c}0.219 \\
(0.820)\end{array}$ & .. \\
\hline$V_{3}$ & .. &.. & $\begin{array}{c}-0.096 \\
(0.107)\end{array}$ & .. & .. & $\begin{array}{c}-0.379^{* * *} \\
(0.002)\end{array}$ & .. & .. & $\begin{array}{c}-0.107^{* * *} \\
(0.004)\end{array}$ \\
\hline Tests $p$-values ${ }^{a}$ : & & & & & & & & & \\
\hline Hansen & 1.000 & 1.000 & 1.000 & 0.157 & 0.083 & 0.253 & 0.104 & 0.101 & 0.115 \\
\hline $\mathrm{AR}(2)$ & 0.380 & 0.382 & 0.353 & 0.283 & 0.458 & 0.094 & 0.291 & 0.301 & 0.291 \\
\hline Wald test & 0.000 & 0.000 & 0.000 & 0.000 & 0.000 & 0.000 & 0.000 & 0.000 & 0.000 \\
\hline Number of Instruments & 411 & 411 & 411 & 51 & 51 & 51 & 51 & 51 & 51 \\
\hline Groups & 72 & 72 & 72 & 72 & 72 & 72 & 72 & 72 & 72 \\
\hline Observations & 1137 & 1137 & 1137 & 1137 & 1137 & 1137 & 1137 & 1137 & 1137 \\
\hline
\end{tabular}

Note: Specifications $I, I I$, and $I I I$ include $V_{1}, V_{2}$, and $V_{3}$ respectively. See text for precise definitions. ***, **, and * denote significance at the one, five, and ten percent level respectively. Coefficient estimates are from two-step Difference GMM with the Windmeijer (2005) correction for small sample bias. All $p$-values are in parentheses. All variables except volatility are measured in natural logs.

a The Hansen $J$-statistic is the robust test for overidentifying restrictions. The null hypothesis is that the instruments as a group are exogenous. AR(2) represents the Arellano-Bond test for second order serial correlation. The Wald test is for the joint significance of all regressors. 
Table 2.9: Coefficient Estimates: System GMM, 1991-2008

\begin{tabular}{|c|c|c|c|c|c|c|c|c|c|}
\hline \multirow{2}{*}{$\begin{array}{l}\text { Variable } \\
\text { Dependent variable: } \text { Real exports }\end{array}$} & \multicolumn{3}{|c|}{ Full Instrument Set } & \multicolumn{3}{|c|}{ Second Lag Only } & \multicolumn{3}{|c|}{ Second Lag Only, Collapsed } \\
\hline & $I$ & II & $I I I$ & $I$ & $I I$ & $I I I$ & $I$ & $I I$ & $I I I$ \\
\hline Real exports (t-1) & $\begin{array}{l}0.979^{* * *} \\
(0.000)\end{array}$ & $\begin{array}{l}0.997^{* * *} \\
(0.000)\end{array}$ & $\begin{array}{l}0.997^{* * *} \\
(0.000)\end{array}$ & $\begin{array}{l}0.939^{* * *} \\
(0.000)\end{array}$ & $\begin{array}{c}0.929^{* * *} \\
(0.000)\end{array}$ & $\begin{array}{c}0.940^{* * *} \\
(0.000)\end{array}$ & $\begin{array}{c}0.956^{* * *} \\
(0.000)\end{array}$ & $\begin{array}{c}0.950^{* * *} \\
(0.000)\end{array}$ & $\begin{array}{l}0.954^{* * *} \\
(0.000)\end{array}$ \\
\hline Domestic real GDP & $\begin{array}{c}0.025 \\
(0.373)\end{array}$ & $\begin{array}{c}0.009 \\
(0.706)\end{array}$ & $\begin{array}{c}0.009 \\
(0.624)\end{array}$ & $\begin{array}{l}0.063^{*} \\
(0.087)\end{array}$ & $\begin{array}{l}0.073^{*} \\
(0.054)\end{array}$ & $\begin{array}{c}0.064 \\
(0.109)\end{array}$ & $\begin{array}{c}0.048 \\
(0.826)\end{array}$ & $\begin{array}{c}0.055 \\
(0.318)\end{array}$ & $\begin{array}{c}0.052 \\
(0.528)\end{array}$ \\
\hline World real GDP & $\begin{array}{l}-0.001 \\
(0.938)\end{array}$ & $\begin{array}{c}0.007 \\
(0.622)\end{array}$ & $\begin{array}{c}0.007 \\
(0.508)\end{array}$ & $\begin{array}{r}-0.016 \\
(0.386)\end{array}$ & $\begin{array}{l}-0.021 \\
(0.242)\end{array}$ & $\begin{array}{r}-0.019 \\
(0.351)\end{array}$ & $\begin{array}{r}-0.886 \\
(0.865)\end{array}$ & $\begin{array}{l}-0.884 \\
(0.458)\end{array}$ & $\begin{array}{l}-0.569 \\
(0.743)\end{array}$ \\
\hline Real effective exchange rate & $\begin{array}{l}-0.151 \\
(0.231)\end{array}$ & $\begin{array}{l}-0.055 \\
(0.618)\end{array}$ & $\begin{array}{l}-0.068 \\
(0.649)\end{array}$ & $\begin{array}{l}-0.097 \\
(0.366)\end{array}$ & $\begin{array}{l}-0.066 \\
(0.496)\end{array}$ & $\begin{array}{l}-0.070 \\
(0.573)\end{array}$ & $\begin{array}{c}-0.581 \\
(0.619)\end{array}$ & $\begin{array}{c}-0.686^{* * *} \\
(0.004)\end{array}$ & $\begin{array}{l}-0.574 \\
(0.330)\end{array}$ \\
\hline Real effective exchange rate (t-1) & $\begin{array}{c}0.086 \\
(0.466)\end{array}$ & $\begin{array}{c}-0.018 \\
(0.874)\end{array}$ & $\begin{array}{l}-0.005 \\
(0.977)\end{array}$ & $\begin{array}{c}0.006 \\
(0.958)\end{array}$ & $\begin{array}{c}-0.025 \\
(0.807)\end{array}$ & $\begin{array}{l}-0.008 \\
(0.958)\end{array}$ & $\begin{array}{c}0.593 \\
(0.690)\end{array}$ & $\begin{array}{c}0.791^{* * *} \\
(0.008)\end{array}$ & $\begin{array}{c}0.624 \\
(0.395)\end{array}$ \\
\hline$V_{1}$ & $\begin{array}{c}-0.597^{* * *} \\
(0.005)\end{array}$ &.. & .. & $\begin{array}{c}-0.549^{* * *} \\
(0.044)\end{array}$ &.. &.. & $\begin{array}{l}-1.297 \\
(0.126)\end{array}$ &.. &.. \\
\hline$V_{2}$ & .. & $\begin{array}{c}-1.196^{\circ} \\
(0.054)\end{array}$ & .. &.. & $\begin{array}{c}-1.148^{*} \\
(0.094)\end{array}$ & .. &.. & $\begin{array}{l}1.069^{*} \\
(0.022)\end{array}$ & .. \\
\hline$V_{3}$ & .. &. & $\begin{array}{c}-0.296^{* * *} \\
(0.006)\end{array}$ & .. & .. & $\begin{array}{c}-0.142^{* *} \\
(0.041)\end{array}$ & .. &.. & $\begin{array}{c}-0.533^{* *} \\
(0.020)\end{array}$ \\
\hline Tests $p$-values ${ }^{a}$ : & & & & & & & & & \\
\hline Hansen & 1.000 & 1.000 & 1.000 & 0.999 & 0.999 & 0.999 & 0.384 & 0.918 & 0.384 \\
\hline $\operatorname{AR}(2)$ & 0.339 & 0.404 & 0.269 & 0.325 & 0.406 & 0.315 & 0.549 & 0.742 & 0.549 \\
\hline Wald test & 0.000 & 0.000 & 0.000 & 0.000 & 0.000 & 0.000 & 0.000 & 0.000 & 0.000 \\
\hline Number of Instruments & 476 & 476 & 476 & 116 & 116 & 116 & 26 & 26 & 26 \\
\hline Groups & 72 & 72 & 72 & 72 & 72 & 72 & 72 & 72 & 72 \\
\hline Observations & 1209 & 1209 & 1209 & 1209 & 1209 & 1209 & 1209 & 1209 & 1209 \\
\hline
\end{tabular}

Note: Specifications $I, I I$, and $I I I$ include $V_{1}, V_{2}$, and $V_{3}$ respectively. See text for precise definitions. ${ }^{* * *},{ }^{* *}$, and ${ }^{*}$ denote significance at the one, five, and ten percent level respectively. Coefficient estimates are from two-step System GMM with the Windmeijer (2005) correction for small sample bias. All $p$-values are in parentheses. All variables except volatility are measured in natural logs.

${ }^{a}$ The Hansen $J$-statistic is the robust test for overidentifying restrictions. The null hypothesis is that the instruments as a group are exogenous. AR(2) represents the Arellano-Bond test for second order serial correlation. The Wald test is for the joint significance of al regressors. 
Table 2.10: Difference and System GMM, Low Income Countries, 1991-2008

\begin{tabular}{|c|c|c|c|c|c|c|}
\hline \multirow[t]{3}{*}{ Variable } & \multicolumn{6}{|c|}{ Dependent variable: Real exports } \\
\hline & \multicolumn{3}{|c|}{ Difference GMM } & \multicolumn{3}{|c|}{ System GMM } \\
\hline & $I$ & $I I$ & $I I I$ & $I$ & $I I$ & $I I I$ \\
\hline Real exports (t-1) & $\begin{array}{c}0.836^{* * *} \\
(0.000)\end{array}$ & $\begin{array}{c}0.812^{* * *} \\
(0.000)\end{array}$ & $\begin{array}{c}0.838^{* * *} \\
(0.000)\end{array}$ & $\begin{array}{c}0.966^{* * *} \\
(0.000)\end{array}$ & $\begin{array}{c}0.935^{* * *} \\
(0.000)\end{array}$ & $\begin{array}{c}0.984^{* * *} \\
(0.000)\end{array}$ \\
\hline Domestic real GDP & $\begin{array}{c}0.467^{* * *} \\
(0.002)\end{array}$ & $\begin{array}{c}0.505^{* * *} \\
(0.001)\end{array}$ & $\begin{array}{c}0.452^{* * *} \\
(0.003)\end{array}$ & $\begin{array}{c}0.037 \\
(0.766)\end{array}$ & $\begin{array}{c}0.070 \\
(0.349)\end{array}$ & $\begin{array}{c}0.029 \\
(0.771)\end{array}$ \\
\hline World real GDP & $\begin{array}{l}-0.314 \\
(0.104)\end{array}$ & $\begin{array}{l}-0.286 \\
(0.191)\end{array}$ & $\begin{array}{l}-0.289 \\
(0.167)\end{array}$ & $\begin{array}{l}-1.138 \\
(0.673)\end{array}$ & $\begin{array}{l}-0.796 \\
(0.628)\end{array}$ & $\begin{array}{l}-1.149 \\
(0.559)\end{array}$ \\
\hline Real effective exchange rate & $\begin{array}{l}-0.126 \\
(0.319)\end{array}$ & $\begin{array}{l}-0.041 \\
(0.660)\end{array}$ & $\begin{array}{l}-0.093 \\
(0.436)\end{array}$ & $\begin{array}{l}-0.369 \\
(0.629)\end{array}$ & $\begin{array}{c}-0.675^{* *} \\
(0.015)\end{array}$ & $\begin{array}{l}-0.338 \\
(0.617)\end{array}$ \\
\hline Real effective exchange rate (t-1) & $\begin{array}{c}0.122 \\
(0.265)\end{array}$ & $\begin{array}{c}0.046 \\
(0.671)\end{array}$ & $\begin{array}{c}0.087 \\
(0.424)\end{array}$ & $\begin{array}{c}0.334 \\
(0.725)\end{array}$ & $\begin{array}{l}0.791^{* *} \\
(0.022)\end{array}$ & $\begin{array}{c}0.327 \\
(0.697)\end{array}$ \\
\hline$V_{1}$ & $\begin{array}{c}-0.470^{* *} \\
(0.025)\end{array}$ &.. & .. & $\begin{array}{c}-1.294^{*} \\
(0.078)\end{array}$ &.. & .. \\
\hline$V_{2}$ & .. & $\begin{array}{c}1.257 \\
(0.025)\end{array}$ & .. & .. & $\begin{array}{l}1.092^{* *} \\
(0.048)\end{array}$ & .. \\
\hline$V_{\mathbf{3}}$ & .. & .. & $\begin{array}{c}-0.092^{* *} \\
(0.011)\end{array}$ & .. & .. & $\begin{array}{c}-0.547^{* * *} \\
(0.008)\end{array}$ \\
\hline Tests $(p-\text { values })^{a}$ : & & & & & & \\
\hline Hansen & 0.117 & 0.175 & 0.172 & 0.352 & 0.935 & 0.621 \\
\hline $\operatorname{AR}(2)$ & 0.226 & 0.252 & 0.227 & 0.285 & 0.762 & 0.261 \\
\hline Wald & 0.000 & 0.000 & 0.000 & 0.000 & 0.000 & 0.000 \\
\hline Number of Instruments & 51 & 51 & 51 & 26 & 26 & 26 \\
\hline Groups & 61 & 61 & 61 & 61 & 61 & 61 \\
\hline Observations & 961 & 961 & 961 & 1022 & 1022 & 1022 \\
\hline
\end{tabular}

Note: Specifications $I, I I$, and $I I I$ include $V_{1}, V_{2}$, and $V_{3}$ respectively. See text for precise definitions. ${ }^{* * *},{ }^{* *}$, and ${ }^{*}$ denote significance at the one, five, and ten percent level respectively. Coefficient estimates are from two-step System GMM with the Windmeijer (2005) correction for small sample bias. All $p$-values are in parentheses. All variables except volatility are measured in natural logs. Difference GMM used only the second lag to instrument endogenous variables (and the first lag was used for predetermined ones), while System GMM used the second lag only collapsed into one vector.

${ }^{a}$ The Hansen $J$-statistic is the robust test for overidentifying restrictions. The null hypothesis is that the instruments as a group are exogenous. AR(2) represents the Arellano-Bond test for second order serial correlation. The Wald test is for the joint significance of all regressors. 


\section{Chapter 3}

\section{Trade and Labour Standards: Will There}

\section{Be a Race to the Bottom?}

\subsection{Introduction}

Developing countries are often accused of "social dumping" - that is, using cheap labour subject to poor working conditions to produce and export goods at "unfairly" low prices (Corden and Vousden, 2001). Not surprisingly, this has led many to call for the tying of labour standards to trade agreements. According to the International Labour Organization (ILO), out of all trade agreements that entered into force between 1990 and 1999, only four percent were tied to labour provisions; between 2000 and 2004, the incidence of labour provisions had increased to almost one-third (Ebert and Posthuma, 2011). The growing prevalence of labour provisions in trade agreements highlights real-world concerns of a "race-to-the-bottom" (RTB) in labour standards as countries enter the world economy.

Labour standards often refer to policies or laws that can, generally speaking, enhance working conditions (i.e., through safer work environments) or improve compensation for work (i.e., through higher wages and benefits). As such, standards set minimum requirements for firms to hire and operate. By nature, standards can be cost-increasing for firms, thus, in the presence of trade, countries may not be 
able to raise labour standards without losing their competitive advantage, and may have the incentive to use domestic policy tools to do otherwise. By reducing production costs of trading firms, for example, a country can impact relative prices and improve international competitiveness. This may trigger a race-to-the-bottom in cost-cutting policy, as countries attempt to undercut each other with the intention of gaining international market shares or profits - a "regulatory chilling" (Bagwell et al., 2002) . These cost-cutting policies could erode labour standards, particularly in countries where the appropriate legislation or enforcement mechanisms are lacking. This scenario is reminiscent of the classic "Prisoner's Dilemma" problem, where agents sub-optimally choose non-cooperation, even though cooperation (i.e., upward harmonization of standards) could potentially increase social welfare (Heintz, 2002).

Certainly the impact of competitive pressures on labour standards is timely given the recent tragedy in Bangladesh, where over 1,000 garment factory workers perished after a factory collapsed on April 24, 2013. Bangladeshi clothing manufacturers are often competing with low-wage countries like Indonesia or Cambodia for large Western export markets. With this recent tragedy, the Bangladeshi government is calling for increasing the minimum wage for garment factory workers, who are some of the poorest in the world.

From an analytical perspective, the idea that trade could lead to a race-to-thebottom in standards is not confined to the labour standards literature. There is a large literature examining whether trade is linked to domestic environmental standards, for example. The basic premise in this literature is similar. That is, concern about the impact of trade on environmental standards is based on the idea that trade could lead to a "pollution-haven" effect, where greater global integration leads to declining environmental regulations in poorer, low-standard countries (Copeland and Taylor, 2004), or that competitive pressures will lead to lobbying for less stringent environmental regulations (Ulph, 1994). 
In the area of trade and labour, early research has examined domestic labour market policies and their implications for trade flows, without explicitly addressing a RTB in standards. Such work includes Brecher (1974), for example, who shows the impact of minimum wages on the pattern of trade in a Heckscher-Ohlin model. While not directly about a RTB in labour standards, given that a minimum wage policy acts as a minimum requirement on firms, it embodies the characteristics of a labour standard. Minimum wages are treated as a cause of unemployment, and abolishing the minimum wage is found to potentially reverse the pattern of trade and reduce welfare. More recently, Alam (1992) uses the Heckscher-Ohlin model to analyze impacts of a number of labour standards on comparative advantage, including minimum wages. An export-sector-specific minimum wage is found to worsen comparative advantage in this sector, independent of its labour- or capital-intensity, while a more generalized minimum wage will depress comparative advantage of the labour-intensive sector only. ${ }^{1}$

Recent literature has attempted to address the possible strategic use of labour standards in international trade. Brown et al. (1996) present a trade model in which countries have incentives to engage in such strategic behaviour. They begin with a partial equilibrium analysis that also relies heavily on the Heckscher-Ohlin model. This is then further expanded to the traditional two country, two good, two factor $(2 \times 2 \times 2)$ general equilibrium model. In the former, the authors treat standards as a policy needed to correct a negative externality in production of a good, thus one that charges firms the marginal social cost of this activity. For a small country, this increase in production costs does not impact the terms of trade, leaving world prices

\footnotetext{
${ }^{1}$ The effects of minimum wages in an open economy have been examined in other contexts as well. For instance, Davis (1998) models the impact of minimum wages on unemployment resulting from trade. In his two-country model, flexible-wage America trades with rigid-wage Europe (i.e. where there are higher minimum wages). Moving from autarky to trade results in an increase in unemployment in Europe. Thus, while not directly addressing a RTB in labour standards, this model shows how there may be a disincentive to have minimum wages in an open economy.
} 
unchanged. Setting standards, in this case, is welfare-increasing. If countries adhere to a common standard, however, the net trade position matters - net exporters will prefer common standards rather than net importers. Importers are impacted by the increase in world price arising from domestic standards implementation abroad, even though they themselves were not subject to it. This outweighs the benefits from internalizing the negative externality domestically.

In their general equilibrium analysis, the authors add more specificity to the standard by assuming that a labour standard detracts resources from a country's labour endowment. ${ }^{2}$ In this model, relative factor intensities in production matter. Making labour relatively more scarce, labour standards increase wages, leading to an increase in the relative world price of the good that is labour-intensive. Thus, countries exporting labour-intensive goods benefit from labour standards, while those exporting capital-intensive ones do not. Countries will have an incentive to set standards unilaterally to benefit from a terms-of-trade improvement if they export the labourintensive good, while those exporting capital-intensive products will set standards too low. Thus, the authors suggest that a RTB in standards is possible in the absence of cooperation for countries with capital-intensive export sectors. They point to this result as an incentive for standards harmonization, with cross-country cooperation on a common standard somewhere in the middle.

Bagwell and Staiger (2001) also point to the possibility of a RTB in standards arising from competitive pressures. The authors link trade and labour standards in the framework of a tariff game. Recognizing that trade liberalization involves tariff concessions, they develop a model in which two countries simultaneously choose tariffs and domestic standards. Standards are modeled generally, representing either labour or environmental standards, and can be either imposed on the production

\footnotetext{
${ }^{2}$ For example, laws limiting (and enforcing) child labour would lower the labour force of a country (Sapir, 1995).
} 
or consumption side. Each government chooses tariffs and standards to maximize national welfare, caring about the impact of standards policy in its trading partner only through the indirect impact on prices. They are able to show that when acting unilaterally, governments choose to restrict market access with inefficiently high tariffs and low standards, resulting in inefficiently low trade volumes. This result lends rather easily to a RTB interpretation, as this inefficiency arises from government incentives to affect the terms of trade in its own favour - a rise in domestic standards worsens the terms of trade for the implementing country.

Others have argued that labour standards are endogenous, depending on societal preferences, endowments, and/or productivity (Sapir, 1995). Differing labour standards will reflect differences in these endogenizing factors, and do not necessarily reflect distortions or inefficiencies in the market (see Srinivasan, 1996 or Casella, 1996 for example). Casella (1996) is able to show by using the $2 \times 2 \times 2$ Heckscher-Ohlin model that trade leads to an endogenous convergence in income, which then results in a convergence of standards. Therefore, convergence is independent of competitive pressures arising from an open market. The relative magnitude and direction of this convergence depends on the relative proportion of low- and high-skilled workers in each country, and the assumption that both countries are democratic. ${ }^{3}$ It follows that a RTB in standards may or may not manifest, depending on these endogenizing factors.

More generally, Maskus (1997) and Martin and Maskus (2001) point to monopsonistic labour markets as a source of social dumping, though their analysis is largely graphical, and does not explicitly address a possible RTB in standards. It is argued that monopsony labour markets could be characteristic to many developing countries, particularly rural areas or localized labour markets. In both papers, the authors point

\footnotetext{
${ }^{3}$ The democratic assumption is required so that workers' interests (i.e. standards) are reflected in government choices.
} 
to freedom of association and collective bargaining rights as a possible labour standard that could mitigate the downward distortion in wages arising from a monopsony. In an open economy, unions could bargain for higher wages, resulting in the efficient competitive wage. However, Maskus (1997) points out that several solutions are possible, with wages either increasing or decreasing depending on the whether we are considering a small or large open economy, the preferences of unions, and relative bargaining power. Some results are also somewhat counterintuitive, with what we would consider as higher labour standards leading to lower wages - Maskus finds that wages could actually fall with the imposition of a union in a large open economy and monopsony in the export sector.

While the dominant perspective in this literature is that international competitive pressures from low-standard poor countries will lead to a RTB in standards in richer countries, Chau and Kanbur (2006) shift the focus to the possible impact this may have on labour standards within developing countries themselves - a "South-South" competition. The authors expand on a traditional Ricardian trade model in which there are two types of developing countries competing for export to a single developed country while simultaneously choosing a high or low domestic standard. Developing countries are split into small and large exporters, with two large exporters competing with many small open economies (the "competitive fringe"). Main results from this model suggest that small exporters will always adopt the lower standard, since this will lead to larger market shares. For large exporting countries however, the relative size of the two competing countries matter. The relatively larger country is more likely to adopt the high labour standard, therefore there is no RTB. Finally, as the size of the competitive fringe grows, there may not be downward competitive pressures on the standards of big exporters. The authors point out that these results depend intricately on the curvature of the Northern demand function.

A key assumption in a large part of this literature is that countries and firms 
face perfectly competitive goods markets. Indeed, as suggested by Dehejia (1998), the Brown et al. (1996) result, for example, relies on the assumption that large countries do not use their market power. It is important to point out, however, that with the introduction of product market power, the incentives for a RTB in standards could be stronger as policies that favour domestic producers could lead to expansion in export market shares and higher profits. In this vein, Brander and Spencer (1985) introduce export subsidies as a source of strategic interaction between countries in an international duopoly model of trade. There are two countries, each with one firm producing a homogeneous good for export to a third market. In the first stage of the two-stage model, governments choose a credible subsidy on exports, with firms simultaneously choosing production in the second stage. The major result from this model is that even though countries have the joint incentive to abstain from export subsidies, there is an incentive to cheat, leading to a non-cooperative Nash equilibrium in which both countries choose positive subsidies. The incentive to cheat comes from the fact that a positive subsidy leads to export market expansion and profit shifting in the subsidy-setting country's favour. While this result does not address labor standards directly, it implies the possibility of a RTB in standards, as lower standards - like the subsidies - reduce the costs of production.

In a recent paper, Jinji (2012) introduces factor market monopsony to an international duopoly model, thereby introducing both imperfect goods and labour markets. The author sets out to theoretically determine the impact of a monopsonistic labour market when countries act strategically. Two countries, North and South, compete in the Northern market rather than a third market as in Brander and Spencer (1985). The Southern labour market is monopsonistic, while that of North is perfectly competitive. In an extension of the model, the author imposes linear demand and supply to examine the impact of a wage-increasing policy. Specifically, the Northern government imposes a requirement that imports from South must be produced adhering 
to a labour standard. This policy has the impact of increasing the wage paid by the firm in South. The main result from this analysis is that labour standards benefit the Southern firm because of its monopsonistic labour market, while harming the Northern firm. This finding relies on the parameters of the demand and supply functions, and reflects an increase in output in South, but a decrease in market share for North. However, the author does not address the possibility of a RTB in wage policy in his model.

The goal of this chapter is to directly examine whether there is a theoretical basis for a race-to-the-bottom in a specific labour standard in the presence of international competitive pressures - something that is currently lacking in the literature. Furthermore, I depart from existing literature that relies on perfectly competitive models, expanding on Brander and Spencer (1985) by introducing labour standards in a model where countries act strategically. I introduce factor market monopsony, which also takes into consideration that monopsonistic labour markets is a possible source of social dumping. This labour market imperfection allows for two key features in the model. First, it captures the idea that depressed labour standards could be the result of employer power in the labour market. As it is well-established, monopsony wages are below the competitive wage in the absence of government intervention. A minimum wage requirement is a policy that can address this inefficiency. Although minimum wages have not typically been used as a labour standard policy, such a wage policy, clearly, reflects one of the characteristics of a labour standard discussed earlier- that is, compensation for work. Therefore, it can be analytically treated as a labour standard and is the specific domestic policy tool I focus on rather than a general standard often referred to in the literature. In this way, monopsony power allows us to endogenize the labour standard.

Secondly, there is research supporting the idea that monopsony labour markets 
are characteristic of many developing or emerging economies. Brummund (2012) empirically establishes, for example, that Indonesian employers have significant labour market power, suggesting that there is evidence of monopsonistic behaviour. Maskus (1997) also suggests that monopsony labour markets could be characteristic to Export Processing Zones (EPZs) that are dominated by one or few employers. For example, with expanding global production linkages and supply chains often comprised of intermediate input-producing developing countries, market power tends to remain with the dominant company or final assembler. As such, labour markets tied to these networks tend to exhibit monopsonistic characteristics (Bacchetta et al., 2009). Thus, introducing a monopsony labour market is a way to account for these tendencies.

Finally, in addition to a monopsonistic labour market we introduce labour subsidies into the model. Taking into account that World Trade Organization (WTO) rules that seek to to limit subsidies in member countries, we examine the model with and without subsidies. Our main findings suggest that strategic trade considerations do not necessarily lead to a RTB in labour standards. In the presence of labour subsidies, we find that governments actually set wages above the competitive wage. ${ }^{4}$ Without a labour subsidy, we find that not only is there no race-to-the-bottom, there is also no labour market distortion, as governments set efficient minimum wages. Overall, our results arise from a market expansion incentive from increasing wages, similar to that in Brander and Spencer (1985).

\subsection{The Model}

Following Brander and Spencer (1985), we also consider a Cournot international duopoly. There are two countries, Home (H) and Foreign (F), each with one firm producing a homogeneous good. Home produces quantity $x$ and Foreign produces

\footnotetext{
${ }^{4}$ Note that here wages refer to the wage inclusive of the wage subsidy. This is developed further in the paper.
} 
quantity $y$ for export to a third market. Each firm has the inverse demand function $p(x+y)$ with $p^{\prime}<0$. There is no consumption in the producing countries, and the third market is the only purchaser of Country $\dot{H}$ and F's exports. ${ }^{5}$ To ensure that reaction functions are downward-sloping, we assume the following standard regularity conditions:

$$
\begin{aligned}
& \pi_{x y}=p^{\prime}+x p^{\prime \prime}<0 \\
& \pi_{y x}^{*}=p^{\prime}+y p^{\prime \prime}<0 \\
& \pi_{x x}<\pi_{x y} \\
& \pi_{y y}^{*}<\pi_{y x}^{*}
\end{aligned}
$$

The first two equations in (3.1) show that home country marginal revenue falls as competitor output increases. These, combined with the second-order conditions $\pi_{x x}<$ 0 and $\pi_{y y}^{*}<0$ lead to the following relationship:

$$
D=\pi_{x x} \pi_{y y}^{*}-\pi_{x y} \pi_{y x}^{*}>0
$$

Conditions (3.1) and (3.2) ensure that the equilibrium is unique and are standard regularity conditions presented in Brander and Spencer (1985).

Labour is the only input in production, and one unit of labour is required to produce one unit of output. Each firm has monopsony power in its own labour market. Thus, firms face an upward-sloping supply curve in the labour market. The inverse supply curves are given by $w=\omega(x)$ and $w^{*}=\omega^{*}(y)$, where $w$ and $w^{*}$ are the wage rates paid by firm $\mathrm{H}$ and $\mathrm{F}$ respectively. Since supply curves are upwardsloping, it follows that $\omega^{\prime}>0$ and $\omega^{* \prime}>0$. We assume that the government in

\footnotetext{
${ }^{5}$ Though we have not explicitly modeled a trade agreement, we may assume that it is exogenous.
} 
each country uses minimum wages as a labour standard, so as to rectify the the firm's monopsony power. In the first stage of the game, governments choose labour standards (wages) simultaneously. In the second stage each firm chooses their output level simultaneously. We will focus on the subgame perfect equilibrium in this game.

\subsubsection{Benchmark Model}

Since the objective of this chapter is to examine how the strategic interaction of the Home and Foreign firms affect the government's choice of the labour standard, we first examine the case of no strategic interaction as a benchmark. Specifically, suppose that each firm takes the output level of the other firm as given, and that these outputs are fixed. In what follows we focus on the Home firm, with the idea that Foreign results are symmetrical. In the absence of strategic interaction among the two firms, Foreign's output level, $y$, does not affect Home's output choices. That is, $y=\bar{y}$, where $\bar{y} \geq 0$. Note that in the extreme case, $\bar{y}=0$ and Home faces no competitor in the third country.

If the Home government does not impose a labour standard, the Home firm faces an upward-sloping labour supply curve and has the following profit-maximization problem:

$$
\stackrel{M a x}{x} \pi=p(x+\bar{y}) x-\omega(x) x
$$

This results in the following first- and second-order conditions:

$$
\begin{gathered}
\pi_{x}=p+x p^{\prime}-\omega-x \omega^{\prime}=0 \\
\pi_{x x}=2 p^{\prime}+x p^{\prime \prime}-2 \omega^{\prime}-x \omega^{\prime \prime}<0
\end{gathered}
$$


Similarly, profit for the Foreign firm, taking $x=\bar{x}$, is given by:

$$
\pi^{*}=p(\bar{x}+y) y-\omega^{*}(y) y
$$

Leading to the first- and second-order conditions:

$$
\begin{gathered}
\pi_{y}^{*}=p+y p^{\prime}-\omega^{*}-y \omega^{* \prime}=0 \\
\pi_{y y}^{*}=2 p^{\prime}+y p^{\prime \prime}-2 \omega^{* \prime}-y \omega^{\prime \prime}<0
\end{gathered}
$$

Let $x_{a}$ and $y_{a}$ be the solutions to (3.4) and (3.7) respectively (Cournot outputs). Define $w_{a} \equiv \omega\left(x_{a}\right)$ and $w_{a}^{*} \equiv \omega\left(y_{a}\right)$. These are the wages that occur in the absence of government intervention (monopsony wages). Once the government imposes a labour standard in the form of a binding minimum wage (i.e., $w>\omega\left(x_{a}\right)$ for Home, $w^{*}>\omega^{*}\left(y_{a}\right)$ for Foreign), the firm must take wages as given. Thus, Home firm's profit maximization problem is as follows.

$$
\stackrel{M a x}{x} \pi=x p(x+\bar{y})-w x
$$

This leads to the first-order condition:

$$
\pi_{x}=p+x p^{\prime}-w=0
$$

Similarly for Foreign we have:

$$
\pi_{y}^{*}=p+y p^{\prime}-w^{*}=0
$$

We see quite readily that the solutions to (3.10) and (3.11) are functions of wages, 
$x(w)$ and $y\left(w^{*}\right) .{ }^{6}$

We turn now to the the first stage in which the government in each country sets the minimum wage. Taking firm's optimal actions into account (that is, the solutions implied by (3.10) and (3.11)), the Home government chooses $w$ to maximize firm profits and workers' surplus, which is the sum of firm profits and workers' surplus:

$$
\stackrel{M a x}{w} V=[x p(x+\bar{y})-w x]+\left[w x-\int_{0}^{x(w)} \omega(l) d l\right]
$$

This simplifies to:

$$
\stackrel{M a x}{w} V=x p(x+\bar{y})-\int_{0}^{x(w)} \omega(l) d l
$$

Given that $\frac{d}{d w} \int_{0}^{x(w)} \omega(l) d l=x^{\prime}(w) \omega(x)$, the government first-order condition is:

$$
\begin{aligned}
{\left[x(w) p^{\prime}+p-w(x)\right] x^{\prime}(w) } & =0 \\
{[w-\omega(x)] x^{\prime}(w) } & =0
\end{aligned}
$$

Where line (3.14) follows from the fact that $w=x p^{\prime}+p$. We can see from (14) that $w=\omega(x)$. Substituting this into equation (10) we have:

$$
x p^{\prime}+p=\omega(x)
$$

Let $x_{b}$ denote the solution to (3.15), and define $w_{b} \equiv \omega\left(x_{b}\right)$. Thus, to reiterate, we have the following first-order conditions and solutions for the Home firm with and without a labour standard:

\footnotetext{
${ }^{6}$ Note that technically these solutions are functions also of competitor (fixed) output, $x(w, \bar{y})$ and $y\left(w^{*}, \bar{x}\right)$.
} 


$$
\begin{aligned}
\omega(x)+\omega^{\prime}(x) x=x p^{\prime}+p & ; x \equiv x_{a} \\
\omega(x)=x p^{\prime}+p & ; x \equiv x_{b}
\end{aligned}
$$

Comparison of (3.16) and (3.17) leads to the following proposition.

\section{Proposition 1:}

In the absence of strategic considerations, the Home government sets the labour standard at the level that completely eliminates the deadweight loss caused by the Home firm's monopsony power. Accordingly, output and wages are unambiguously higher after the imposition of the labour standard: $x_{b}>x_{a}, w_{b}>w_{a}$.

\section{Proof:}

Evaluated at the solution, by equation (3.16) we have that:

$$
\begin{aligned}
\omega\left(x_{a}\right)+\omega^{\prime}\left(x_{a}\right) x_{a} & =x_{a} p^{\prime}+p \\
w_{a}+\omega^{\prime}\left(x_{a}\right) x_{a} & =x_{a} p^{\prime}+p
\end{aligned}
$$

Since the labour supply curve is upward-sloping, we know that $\omega^{\prime}\left(x_{a}\right)>0$. Thus for all $x_{a}>0$ we have:

$$
w_{a}<x_{a} p^{\prime}+p
$$

If, on the other hand, we take equation (3.17) and evaluate it at the solution: 


$$
\begin{aligned}
\omega\left(x_{b}\right) & =x_{b} p^{\prime}+p \\
w_{b} & =x_{b} p^{\prime}+p
\end{aligned}
$$

Let us now evaluate the first-order condition the Home firm in the absence of government intervention (equation (3.17)) at the governmentinduced solution, $x_{b}>0$ :

$$
\begin{aligned}
\left.\frac{\partial \pi}{\partial x}\right|_{x=x_{b}} & =\underbrace{x_{b} p^{\prime}+p-\omega\left(x_{b}\right)}_{=0 \text { by }(17)}-\omega^{\prime}\left(x_{b}\right) x_{b} \\
& =-\omega^{\prime}\left(x_{b}\right) x_{b}<0
\end{aligned}
$$

The last inequality follows from the fact that $\omega^{\prime}>0$ and so $-\omega^{\prime}<0$. Equation (20) implies that decreasing output is necessary to increase the Home firm's profit and satisfy the optimality condition. Thus given that $x_{a}$ solves (3.16), it must be that $x_{b}>x_{a}$ for all interior solutions. Therefore, we have:

$$
\begin{aligned}
x_{b} & >x_{a} \\
\omega\left(x_{b}\right) & >\omega\left(x_{a}\right), \text { Since } \omega^{\prime}>0 \\
w_{b} & >w_{a}
\end{aligned}
$$

Where line (3.21) follows from the fact that $w_{i} \equiv \omega\left(x_{i}\right)$ for $i \epsilon\{a, b\}$. This completes the proof. 
Note that the right-hand side of equation (3.18) is the marginal revenue product of labour, while the left-hand side, represents marginal cost. Clearly, the value of the last unit produced is greater than the wage the worker receives. Thus, $w_{a}$ is inefficiently low. In the absence of government intervention, there is a deadweight loss arising from monopsony power in the labour market. We can see quite readily from equation (19) that the government-imposed minimum wage is equal to the marginal revenue product of labour, thus it is efficient, and has eliminated the deadweight loss caused by monopsony power. Government intervention results in higher wages. This is a standard result for monopsonistic labour markets. ${ }^{7}$

\subsubsection{Strategic Interaction}

We now add strategic considerations to the model, turning to the scenario in which Home and Foreign compete in the export market. Output of the competing firm is no longer constant. As before, we begin with no government intervention. Firms in Home and Foreign choose wages to maximize profits:

$$
\begin{aligned}
& \stackrel{\operatorname{Max}}{x} \pi=x p(x+y)-\omega(x) x \\
& \stackrel{\operatorname{Max}}{y} \pi^{*}=y p(x+y)-\omega^{*}(y) y
\end{aligned}
$$

This leads to the first-order conditions:

\footnotetext{
${ }^{7}$ Recall that in a monopsonistic labour market, the marginal cost of labour curve lies above the upward-sloping labour supply curve. That is, if an employer wants to hire an additional unit of labour, it must not only pay a higher wage to that worker, but also to all existing workers. Thus, monopsonists have the incentive to depress wages below the competitive equilibrium, resulting in a deadweight loss.
} 


$$
\begin{aligned}
& x p^{\prime}+p=\omega(x)+\omega^{\prime}(x) x \\
& y p^{\prime}+p=\omega^{*}(y)+\omega^{* \prime}(y) y
\end{aligned}
$$

Let $x_{c}$ and $y_{c}$ denote the solution to the system of equations in (3.23), which are Cournot quantities. These quantities give us equilibrium wages in the absence of government intervention, $w_{c}=\omega\left(x_{c}\right)$ and $w_{c}^{*}=\omega^{*}\left(y_{c}\right)$.

In the presence of minimum wages, $w$ and $w^{*}$, firms in each country take wages as given and face the following profit maximization problems:

$$
\begin{aligned}
& \stackrel{{ }_{x}^{M a x}}{x}=x p(x+y)-w x \\
& { }_{y}^{M a x} \pi^{*}=y p(x+y)-w^{*} y
\end{aligned}
$$

This leads to first-order conditions:

$$
\begin{aligned}
& x p^{\prime}+p=w \\
& y p^{\prime}+p=w^{*}
\end{aligned}
$$

The solution to the system of first-order conditions in (3.25) leads to reaction functions $x\left(w, w^{*}\right)$ and $y\left(w, w^{*}\right)$. Clearly, now each country's production depends not only on domestic wages but also on competitor country wages. Let us now examine the implications of this. 


\section{Comparative Statics}

Comparative static effects of the impact of wages on output can be derived from total differentiation of firm first-order conditions. Note that for notational convenience, $x=x\left(w, w^{*}\right), y=y\left(w, w^{*}\right)$, and $\pi_{x}=\pi_{x}\left(x, y, w, w^{*}\right)$ and the corresponding equations for Foreign. After some algebra, holding Foreign wages constant $\left(d w^{*}=0\right)$ we have the following:

$$
\begin{aligned}
& \frac{\partial x}{\partial w}=\frac{\pi_{y y}^{*}}{D}<0 \\
& \frac{\partial y}{\partial w}=\frac{-\pi_{y x}^{*}}{D}>0
\end{aligned}
$$

We can see from (3.26) that an increase in domestic wages decreases domestic output, as we might anticipate. Furthermore, (3.27) shows that an increase in domestic wages results in a transfer of market power abroad, as Foreign output increases. Similarly, holding changes in domestic wages constant $(d w=0)$, we have the following:

$$
\begin{aligned}
& \frac{\partial x}{\partial w^{*}}=\frac{-\pi_{x y}}{D}>0 \\
& \frac{\partial y}{\partial w^{*}}=\frac{\pi_{x x}}{D}<0
\end{aligned}
$$

Thus comparative statics for a change in Foreign wages are symmetrical.

\subsubsection{Strategic Interaction and Minimum Wages}

We now wish to determine whether minimum wages differ when countries are acting strategically. In order to do so, we must take into account that minimum wages imposed by governments are paid by firms facing an upward-sloping labour supply curve. It is possible that workers may not supply the levels of labour needed at these 
wages. Figure 3.1 below depicts such a scenario, with the competitive equilibrium represented by point $\mathrm{A}$. We can see for any minimum wage below the competitive equilibrium, the marginal product of labour exceeds actual labour supply, leading to a shortage in workers.

Figure 3.1: Monopsonistic Labour Market

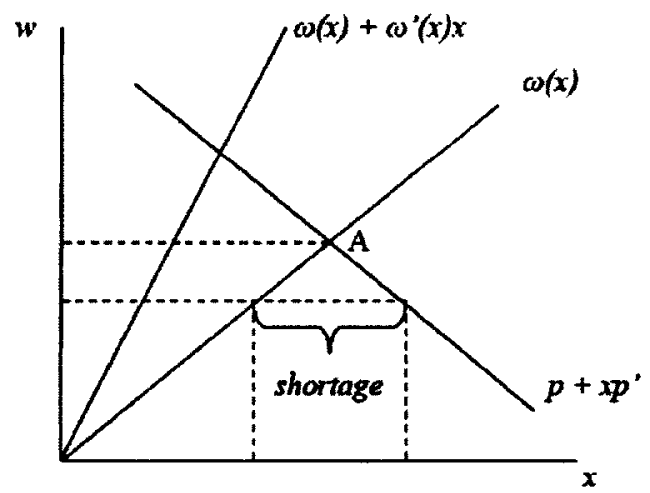

To further illustrate this point, consider the Home government's maximization problem when accounting for strategic interaction:

$$
\stackrel{M_{w} a x}{w} V=\left\{x\left(w, w^{*}\right) p\left[x\left(w, w^{*}\right)+y\left(w, w^{*}\right)\right]-w x\left(w, w^{*}\right)\right\}+\left[w x\left(w, w^{*}\right)-\int_{0}^{x\left(w, w^{*}\right)} \omega(l) d l\right]
$$

With some algebra, the first-order condition associated with (30) simplifies to:

$$
\frac{\partial V}{\partial w}=x p^{\prime} \frac{\partial y\left(w, w^{*}\right)}{\partial w}+[w-\omega(x)] \frac{\partial x\left(w, w^{*}\right)}{\partial w}=0
$$

From (3.31) we see quite readily that $w<\omega(x)$ since $x p^{\prime} \frac{\partial y\left(w, w^{*}\right)}{\partial w}<0$ and $\frac{\partial x\left(w, w^{*}\right)}{\partial w}<0$. Let $w_{d}$ solve the first-order condition above and $w_{d}^{*}$ solve that for Foreign. These minimum wages imply an equilibrium output level, $x_{d} \equiv x\left(w_{d}, w_{d}^{*}\right)$. With an upwardsloping labour supply curve and since $w_{d}<\omega\left(x_{d}\right)$, there are too few workers willing 
to supply labour at $w_{d}$. As we can see from Figure 3.2 below, at a wage rate of $w_{d}$, the supply of labour is only $x_{o}$. A wage rate of $\omega\left(x_{d}\right)$ is required to have $x_{d}$ units of labour. Thus, while government intervention seeks to expand output, the monopsonist cannot employ enough workers to do so without an additional policy tool that could increase the minimum wage to $\omega\left(x_{d}\right)$.

Figure 3.2: Home Labour Market

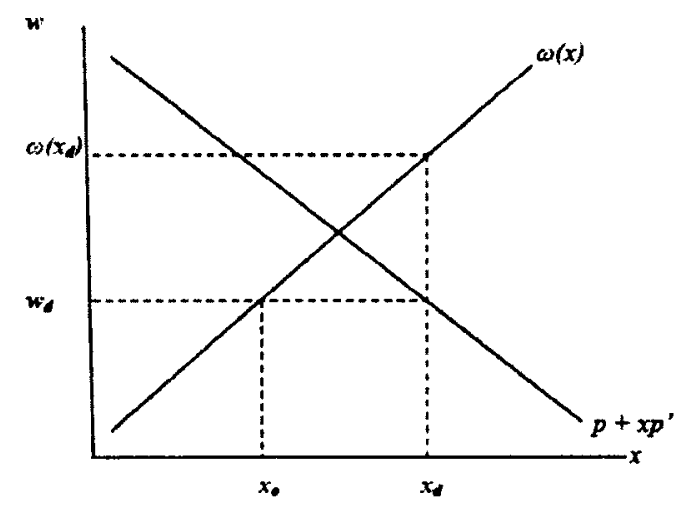

One way to deal with this scenario is to introduce labour (wage) subsidies to the model. Note that labour subsidies are not uncommon in the real world. Burns, et al. (2010) point the role that different sorts of firm-side subsidies have played in South American countries to encourage firms to hire more workers. ${ }^{8}$ In a similar vein, we could easily consider a firm-side subsidy in our model. An optimal wage subsidy in our model would be one that satisfies the FOC in (3.31), thus one that equals to $\omega\left(x_{d}\right)-w_{d}$. In this way, a labour subsidy allows firms to achieve the desired level of employment while satisfying optimality. For completeness, we therefore consider two scenarios - one in which the governments are allowed to offer wage subsidies and one in which they are not. ${ }^{9}$

\footnotetext{
${ }^{8}$ Training-linked subsidies for example have been used in Chile, Argentina, Peru, and Uruguay (Burns et al., 2010).

${ }^{9}$ Note that while we did not explicitly consider wage subsidies in the benchmark model of no strategic interaction, they are implicitly zero since governments are able to implement optimal
} 


\section{Wage Subsidies}

Suppose that governments are allowed to offer wage subsidies $\left(s, s^{*}\right)$ which are financed through lump-sum taxes $\left(T, T^{*}\right)$. As before, an asterisk denotes a Foreign country variable. The Home government's maximization problem is as follows:

$$
\begin{gathered}
\stackrel{\operatorname{Max}}{w} \quad V=\left\{x\left(w, w^{*}\right) p\left[x\left(w, w^{*}\right)+y\left(w, w^{*}\right)\right]-w x\left(w, w^{*}\right)\right\} \\
+\left[w x\left(w, w^{*}\right)-\int_{0}^{x\left(w, w^{*}\right)} w(l) d l\right]+s x\left(w, w^{*}\right)-T \\
\text { s.t. } s x=T
\end{gathered}
$$

We may substitute the government budget constraint into the objective function and with some further simplication we are left with the exact same maximization problem and first-order condition in (3.30) and (3.31). The Foreign government maximization problem and first order condition has a symmetrical result:

$$
\begin{array}{cc}
\stackrel{M a x}{w^{*}} & V^{*}=\left\{y\left(w, w^{*}\right) p\left[x\left(w, w^{*}\right)+y\left(w, w^{*}\right)\right]-w^{*} y\left(w, w^{*}\right)\right\} \\
& +\left[w^{*} y\left(w, w^{*}\right)-\int_{0}^{y\left(w, w^{*}\right)} \omega^{*}(l) d l\right]+s^{*} y\left(w, w^{*}\right)-T^{*} \\
\text { s.t. } s^{*} y=T^{*} & \begin{array}{c}
F O C \\
w^{*}
\end{array} \\
& \frac{\partial V^{*}}{\partial w^{*}}=\frac{\partial x\left(w, w^{*}\right)}{\partial w^{*}} y p^{\prime}+\left[w^{*}-\omega^{*}(y)\right] \frac{\partial y\left(w, w^{*}\right)}{\partial w^{*}}=0
\end{array}
$$

Let $w_{d}$ solve (3.31) and $w_{d}^{*}$ solve (3.34). These are the net wage rates paid by firms, exclusive of the subsidy. Clearly these first-order conditions imply that $w_{d}<\omega\left(x_{d}\right)$ and $w_{d}^{*}<\omega^{*}\left(y_{d}\right)$, as explained earlier. In order to have these wages while simultaneously achieving the desired output levels of $x_{d}$ at Home and $y_{d}$ in Foreign implied 
by the optimality conditions, each government will have to offer a wage subsidy that makes up the difference:

$$
\begin{aligned}
& s_{d}=\omega\left(x_{d}\right)-w_{d} \\
& s_{d}^{*}=\omega^{*}\left(y_{d}\right)-w_{d}^{*}
\end{aligned}
$$

In this analysis, we suppose that the minimum wage is expressed in terms of the actual wages received by workers (i.e. the subsidy-inclusive wage), denoted by $\hat{w}_{d}$ and $\hat{w}_{d}^{*}$ for Home and Foreign respectively. It follows that $\hat{w}_{d}=w_{d}+s$ and $\hat{w}_{d}^{*}=w_{d}^{*}+s^{*}$. Taking into account what we know about optimal subsidies, we have that $\hat{w}_{d}=\omega\left(x_{d}\right)$ and $\hat{w}_{d}^{*}=\omega^{*}\left(y_{d}\right)$. This leads to the following propositions.

\section{Proposition 2:}

In the presence of strategic considerations, each government sets the labour standard at a level above what is needed to eliminate the deadweight loss caused by monopsony power.

\section{Proof:}

A wage that eliminates the deadweight loss from monopsony power is equal to the marginal revenue product of labour. Equation (3.25) implies that $w_{d}=x_{d} p^{\prime}+p$. Note, however, that (31) implies that $w_{d}<\omega\left(x_{d}\right)$. Taken together, we have that $\omega\left(x_{d}\right)>x_{d} p^{\prime}+p$. Given that $\hat{w}_{d}=\omega\left(x_{d}\right)$ we have that $\hat{w}_{d}>x_{d} p^{\prime}+p$. Thus, the minimum wage is higher than the marginal product of labour.

We may now compare the strategic minimum wage to the other outcomes we have discussed in this chapter. The following propositions highlight these relationships. 
First, we compare strategic minimum wages to those that prevail in the absence of strategic considerations and to the strategic minimum wage less the labour subsidy.

\section{Proposition 3:}

At $\bar{y}=y_{d}$, we have that $w_{d}<w_{b}<\hat{w}_{d}$.

\section{Proof:}

Recall $w_{d}$ solves (3.31). To determine how $w_{d}$ compares to $w_{b}$, let us evaluate (3.31) at $w=w_{b}$ :

$$
\begin{gathered}
\frac{\partial V}{\partial w}=[w-\omega(x)] \frac{\partial x\left(w, w^{*}\right)}{\partial w}+x p^{\prime} \frac{\partial y\left(w, w^{*}\right)}{\partial w}=0 \\
\left.\frac{\partial V}{\partial w}\right|_{w=w_{b}}=x p^{\prime} \frac{\partial y\left(w, w^{*}\right)}{\partial w}<0
\end{gathered}
$$

Since (3.37) is negative, this means that decreasing wages is necessary to satisfy the government's optimality condition. It follows then that $w_{d}<w_{b}$. We now wish to compare quantities $x_{b}$ and $x_{d}$, holding $\bar{y}=y_{d}$. With a downward-sloping labour demand curve and the fact that $w_{d}<w_{b}$, it follows that $x_{b}<x_{d}$. Given an upward-sloping labour supply function, this then implies the following:

$$
\omega\left(x_{d}\right)>\omega\left(x_{b}\right) \rightarrow \hat{w}_{d}>w_{b}
$$

Where the arrow follows from the definition of $\hat{w}_{d}$ and $w_{b}$. Taken together with what we know from Proposition 2, and using that $w_{d}<$ $w_{b}$, we have $w_{d}<w_{b}<\hat{w}_{d}$.

Proposition 3 suggests that while strategic considerations lead governments to choose inefficiently high minimum wages, this distortion is arising from the labour subsidy, as 
the strategic minimum wage less the subsidy is actually lower than the minimum wage in the absence of trade. Monopsony in the labour market requires that governments subsidize wages paid by the firm in order to commit to the higher level of output desired by government policy.

We now turn to comparing the strategic minimum wage to strategic wages in the absence of government intervention. Once again, the results for Foreign are symmetric and are thus not reported here. Recall the first-order condition under strategic interaction without government intervention for the Home firm in equation (23). This leads to the following proposition.

\section{Proposition 4:}

In the presence of strategic considerations, each government sets a labour standard that is higher than what occurs in the absence of government intervention $\left(w_{c}<\hat{w}_{d}\right)$.

\section{Proof:}

Let us evaluate the first-order condition in (3.23) at the output that prevails under strategic interaction and government intervention, $x=$ $x_{d}:$

$$
\left.\frac{\partial \pi}{\partial x}\right|_{x=x_{d}}=w_{d}-\hat{w}_{d}-\omega^{\prime}\left(x_{d}\right) x_{d}<0
$$

Where the negativity of (3.40) follows from the fact that $w_{d}-\hat{w}_{d}<0$ and that $-\omega^{\prime}\left(x_{d}\right) x_{d}<0$. Thus, the output level that satisfies this must be lower than $x_{d}$. It follows that $x_{c}<x_{d}$ for the optimality condition to be met. By the monotonicity of $\omega(\cdot)$, we have that $\omega\left(x_{c}\right)<\omega\left(x_{d}\right)$, which by definition means that $w_{c}<\hat{w}_{d}$.

Note that Proposition 4 implies that there is no RTB in labour standards, as strategic interaction actually leads governments to raise the minimum wage. This result 
reflects the incentive in each country to encourage its firm to expand output. That is, with upward-sloping labour supply curves, raising the minimum wage also raises employment, which, in turn, leads to expansions in output.

While it may not be the case that countries set their labour standards cooperatively, examining the cooperative solution is useful in that it reiterate the result that the non-cooperative minimum wage is too high. Thus, turning now to welfare effects, consider the maximization of joint welfare between Home and Foreign:

$$
\begin{aligned}
& \stackrel{\operatorname{Max}}{w, w^{*}} \quad G=V+V^{*}=\left[x\left(w, w^{*}\right)+y\left(w, w^{*}\right)\right] p\left[x\left(w, w^{*}\right)+y\left(w, w^{*}\right)\right]+s x+s^{*} y \\
& -\int_{0}^{x\left(w, w^{*}\right)} \omega(l) d l-\int_{0}^{y\left(w, w^{*}\right)} \omega^{*}(l) d l-T-T^{*} \\
& \text { s.t. } s x+s^{*} y=T+T^{*}
\end{aligned}
$$

This has the following first-order condition:

$$
\begin{gathered}
\frac{\partial G}{\partial w}=\frac{\partial V}{\partial w}+\frac{\partial V^{*}}{\partial w}=0 \\
\frac{\partial G}{\partial w}=x p^{\prime} \frac{\partial y\left(w, w^{*}\right)}{\partial w}+[w-\omega(x)] \frac{\partial x\left(w, w^{*}\right)}{\partial w}+y p^{\prime} \frac{\partial x\left(w, w^{*}\right)}{\partial w}+\left[w^{*}-\omega^{*}(y)\right] \frac{\partial y\left(w, w^{*}\right)}{\partial w}(3 \\
\frac{\partial G}{\partial w^{*}}=\frac{\partial V}{\partial w^{*}}+\frac{\partial V^{*}}{\partial w^{*}}=0 \\
\frac{\partial G}{\partial w^{*}}=x p^{\prime} \frac{y\left(w, w^{*}\right)}{\partial w^{*}}+[w-\omega(x)] \frac{x\left(w, w^{*}\right)}{\partial w^{*}}+y p^{\prime} \frac{\partial x\left(w, w^{*}\right)}{\partial w^{*}}+\left[w^{*}-\omega^{*}(y)\right] \frac{\partial y\left(w, w^{*}\right)}{\partial w^{*}}
\end{gathered}
$$

The preceding FOCs lead to the following proposition.

\section{Proposition 5:}

Starting from $\left(\hat{w}_{d}, s_{d}\right)$ and $\left(\hat{w}_{d}^{*}, s_{d}^{*}\right)$, joint welfare will increase if each government reduces the labour standard and wage subsidy.

\section{Proof:}

For notational simplicity, let $x_{w} \equiv \frac{\partial x\left(w, w^{*}\right)}{\partial w}$ and $y_{w} \equiv \frac{\partial y\left(w, w^{*}\right)}{\partial w}$. Let 
us evaluate (3.41) at the optimal minimum wages set by $\mathrm{H}$ and $\mathrm{F}$ independently (which also imply the optimal wage subsidies):

$$
\begin{aligned}
\left.\frac{\partial G}{\partial w}\right|_{\substack{w=\hat{w}_{d} \\
w^{*}=\hat{w}_{d}^{*}}} & =x_{d} p^{\prime} y_{w}+y_{d} p^{\prime} x_{w} \\
& =y_{d} p^{\prime}\left(\frac{x_{d}}{y_{d}} y_{w}+x_{w}\right) \\
& =y_{d} p^{\prime}\left[x_{w}-\left(\frac{x_{d}}{y_{d}}\right) \frac{\pi_{y x}^{*}}{D}\right] \\
& =y_{d} p^{\prime} x_{w}\left[1-\left(\frac{x_{d}}{y_{d}}\right) \frac{\pi_{y x}^{*}}{\pi_{y y}^{*}}\right]
\end{aligned}
$$

Note that since Home and Foreign are identical, it follows that $\frac{x_{d}}{y_{d}}=1$. We know that $y_{d} p^{\prime} x_{w}>0$. Note that from the regularity conditions we have that:

$$
\begin{gathered}
\pi_{y x}^{*}-\pi_{y y}^{*}>0 \\
\rightarrow \frac{\pi_{y x}^{*}}{\pi_{y y}^{*}}>1
\end{gathered}
$$

The inequality in (3.45) implies that (3.44) is negative. Therefore, it follows that a reduction in the labour standard $\hat{w}_{d}$ will increase joint welfare. Note that results are symmetrical for Foreign and are suppressed. It is important to point out that $\hat{w}_{d}=w_{d}+s_{d}$, or $s_{d}=$ $\hat{w}_{d}-w_{d}$. A reduction in the labour standard thus translates directly into a reduction in the wage subsidy. Similarly, a decrease in the wage subsidy itself directly reduces the labour standard. Therefore we have that decreasing the wage subsidy, $s_{d}$, also increases joint welfare. 
Proposition 5 implies that strategic minimum wages are sub-optimal, with welfare gains possible from a lower minimum wage and labour subsidy. This is not surprising given that we have already established that $\hat{w}_{d}$ is inefficiently high - above the competitive equilibrium wage. This overcompensation leads to another distortion via the labour subsidy, which, in turn, is welfare-reducing. It is interesting to note here, however, that we do not have a race-to-the-bottom in labour standards in the absence of cooperation. In the preceding analysis, we see again that strategic interaction leads governments to actually set labour standards too high. As before, this result is stemming from the incentive to expand output (i.e., market share). We now turn to the case in which governments are restricted from using wage subsidies.

\section{No Subsidies}

Suppose that due to international trade rules (say, through the WTO), countries are prevented from using wage subsidies. The Home and Foreign governments now face the following constrained maximization problems:

$$
\begin{gathered}
\stackrel{M a x}{w} \quad V=\left\{x\left(w, w^{*}\right) p\left[x\left(w, w^{*}\right)+y\left(w, w^{*}\right)\right]-w x\left(w, w^{*}\right)\right\}+\left[w x\left(w, w^{*}\right)-\int_{0}^{x\left(w, w^{*}\right)} \omega(l) d l\right] \\
\text { such that } w \geq \omega(x) \\
\begin{array}{c}
M a x \\
w^{*}
\end{array} \quad V^{*}=\left\{y\left(w, w^{*}\right) p\left[x\left(w, w^{*}\right)+y\left(w, w^{*}\right)\right]-w^{*} y\left(w, w^{*}\right)\right\}+\left[w^{*} y\left(w, w^{*}\right)-\int_{0}^{y\left(w, w^{*}\right)} \omega^{*}(l) d l\right] \\
\text { such that } w^{*} \geq \omega^{*}(y)
\end{gathered}
$$

We examine results for the Home country using the standard Lagrangian for constrained maximization:

$$
\mathcal{L}=V+\lambda[w-\omega(x)]
$$


This has the following Kuhn Tucker conditions:

$$
\begin{gathered}
\frac{\partial \mathcal{L}}{\partial w}=\frac{\partial x}{\partial w} p+x p^{\prime}\left(\frac{\partial x}{\partial w}+\frac{\partial y}{\partial w}\right)-\frac{\partial x}{\partial w} \omega(x)+\lambda\left[1-\omega^{\prime}(x) \frac{\partial x}{\partial w}\right]=0 \\
\frac{\partial \mathcal{L}}{\partial \lambda}=w-\omega(x) \geq 0 \\
\lambda[w-\omega(x)]=0, \lambda \geq 0
\end{gathered}
$$

Let $w_{e}$ solve these equations and let $w_{e}^{*}$ solve the corresponding equations for Foreign. These imply optimal output in Home, $x_{e} \equiv x\left(w_{e}, w_{e}^{*}\right)$. Note that the first-order condition in (51) simplifies to the following:

$$
\frac{\partial \mathcal{L}}{\partial w}=x p^{\prime} \frac{\partial y}{\partial w}+[w-\omega(x)] \frac{\partial x}{\partial w}+\lambda\left[1-\omega^{\prime}(x) \frac{\partial x}{\partial w}\right]=0
$$

We must consider two cases. In the first case, $\lambda=0$ and $w>\omega(x)$. Note, however, that this implies that $(3.52)$ is positive, leading to a solution in which $w<\omega(x)$ - a contradiction. Thus the solution $x_{e}$ must satisfy $\lambda>0$ and $w_{e}=\omega\left(x_{e}\right)$ since $\left[1-\omega^{\prime}(x) \frac{\partial x}{\partial w}\right]>0$. These results lead to the following proposition.

\section{Proposition 6:}

In the presence of strategic considerations, the prohibition of wage subsidies will lead to labour standards that completely eliminate the deadweight loss caused by monopsony power.

\section{Proof:}

A wage that eliminates the deadweight loss from monopsony power will be equal to the marginal revenue product of labour. With government intervention and strategic interaction, firms take wages as given, but output choices depend on rival country wages. Consider the FOC for the Home firm in (3.25) evaluated at $x \equiv x_{e}$ : 


$$
w_{e}=p+x_{e} p^{\prime}
$$

Clearly, the righthand side of the above equation is the marginal revenue product of labour. The optimal minimum wage $w_{e}=\omega\left(x_{e}\right)$ is efficient and there is no deadweight loss.

Proposition 6 suggests that once we abolish labour subsidies, governments efficiently set minimum wages, even in the presence of international pressures. Once again, there is no RTB in wages - an increase in wages leads to an expansion in output. As before, the incentive to expand output leads governments to set higher minimum wages. Note, however, we do not have the upward distortion that was present with wage subsidies. The gains from eliminating the monopsony distortion outweigh the increase in production costs for the firm.

\subsection{Conclusions}

In this chapter we have attempted to address real-world concerns that trade may lead to a race-to-the-bottom in labour standards in the context of Cournot competition. This is in light of the fact that there is a growing prevalence of social clauses in trade agreements, and a general concern that a country's competitive advantage from say, cheap labour, is deemed morally illegitimate, and therefore "unfair" (Bhagwati, 1995). Starting from the premise that labour standards are put in place to address monopsony power in labour markets, we have shown in a simple theoretical framework that strategic trade considerations may actually lead to countries setting higher labour standards.

The major implication from the model is that international rivalry in product markets (Cournot competition) does not necessarily lead to a RTB in labour standards. 
This result stems from monopsonistic labour markets, where welfare-maximizing governments actually have the incentive to increase wages in an attempt to increase employment and output of firms. Therefore, to the extent that race-to-the bottom in labour standards is a real problem, it is caused not by international rivalry in product markets, but by the failure of governments to maximize their domestic welfare.

In a real-world context, weak institutions could result in such market failure. Though labour standard policies may exist in many developing countries, for example, it is possible that they are poorly or sporadically enforced. Indeed, evidence seems to suggest that minimum wage non-compliance is pervasive in developing countries (Basu et al. 2010). Furthermore, our result that there need not be a RTB in minimum wages appears to be echoed in the empirical literature that is rampant with varied findings. ${ }^{10}$ Empirically, it remains to be seen whether employer power in the labour market can lead to a RTB in labour standards with international competitive pressures.

Variations to this model are possible. For example, we may consider the scenario in which a labour standard is only imposed in one country (say, in Home). In this case, the Home government would choose the labour standard in the first stage. It is possible also to consider a model without a third market, where the good is sold in the Home country instead. This would alter the welfare function of the Home government. Furthermore, we could extend the model to consider an oligopsonistic labour market. Another useful extension would be to consider Bertrand competition. As Eaton and Grossman (1986) have pointed out, Bertrand conjectures reverse the Cournot result established by Brander and Spencer (1985) in that governments actually have an incentive to impose taxes rather than subsidies on the firm. Given the debates in the literature, it would be useful to explore the implications of Bertrand competition and how the Cournot results from this chapter compare, and conditions under which they would coincide or differ from the Bertrand case. I point to these extensions as areas

\footnotetext{
${ }^{10}$ See Kucera and Sarna (2006), Dehejia and Samy (2011), or Bonnal (2010) for example.
} 
of future research.

\section{References}

Alam, A. (1992), Labor standards and comparative advantage. Ph.D. thesis, Columbia University, Unpublished doctoral dissertation.

Bacchetta, M., E. Ernst, J.P. Bustamante, International Labour Organization, and World Trade Organization (2009), Globalization and Informal Jobs in Developing Countries. International Labour Organization.

Bagwell, K., P. Mavroidis, and R. Staiger (2002), "It's a question of market access." The American Journal of International Law, 96, 56-76.

Basu, A., N. Chau, and R. Kanbur (2010), "Turning a blind eye: Costly enforcement, credible commitment and minimum wage laws." Economic Journal, 120, 244-269.

Bhagwati, J. (1995), "Trade liberalizatoin and fair trade demands: Addressing environmental and labour standards issues." World Economy, 18, 745-759.

Bonnal, M. (2010), "Export performance, labor standards and institutions: Evidence from a dynamic panel data model." Journal of Labor Research, 31, 53-66.

Brander, J. and B. Spencer (1985), "Export subsidies and international market share rivalry." Journal of International Economics, 18, 83-100.

Brecher, R. (1974), "Minimum wage rates and the pure theory of international trade." The Quarterly Journal of Economics, 88, 98-116.

Brown, D., A. Deardorff, and R. Stern (1996), "International labor standards: a theoretical analysis." In Fair Trade and Harmonization: Prerequisites for Free Trade? (J Bhagwati and R. Hudec, eds.), volume 1, chapter 5, 227-280, MIT Press. 
Brummund, P. (2012), "Variation in monopsonistic behaviour across establishments: evidence from the Indonesian labour market."

Burns, J., L. Edwards, and K. Pauw (2010), "Wage subsidies to combat unemployment and poverty." Technical report.

Casella, A. (1996), "Free trade and evolving standards." In Fair Trade and Harmonization: Prerequisites for Free Trade? (J Bhagwati and R. Hudec, eds.), volume 1, chapter 3, 119-158, MIT Press.

Chau, N. and R. Kanbur (2006), "The race to the bottom, from the bottom." Economica, 73, 193-228.

Copeland, B.. and M. S. Taylor (2004), "Trade, growth, and the environment." Journal of Economic Literature, 42, 7-71.

Corden, W and N. Vousden (2001), "Paved with good intentions: social dumping and raising labour standards in developing countries." In Globalisation Under Threat: The Stability of Trade Policy and Multilateral Agreements (Z. Drábek, ed.), 124146, Edward Elgar Publishing, Incorporated.

Davis, D. (1998), "Does european unemployment prop up american wages? national labor markets and global trade." American Economic Review, 88, 478-94.

Dehejia, V. (1998), "Can standards immiserize?" Economics Letters, 59, 361-366.

Dehejia, V. and Y. Samy (2011), "Labour standards and economic integration in the European Union: A gravity model approach." International Trade Journal, 25, $581-618$.

Eaton, J. and G. Grossman (1986), "Optimal trade and industrial policy under oligopoly." The Quarterly Journal of Economics, 101, 383-406. 
Ebert, F. and A. Posthuma (2011), "Labour provisions in trade agreements: current trends and perspectives." Technical report, International Institute of Labour Studies, International Labour Organization.

Heintz, J. (2002), "Global labor standards: Their impact and implementation." Technical report.

Jinji, N. (2012), "Factor market monopsony and international duopoly." Journal of International Trade \& Economic Development, 21, 271-286.

Kucera, D. and R. Sarna (2006), "Trade union rights, democracy, and exports: A gravity model approach." Review of International Economics, 14, 859-882.

Martin, W. and K. Maskus (2001), "Core labor standards and competitiveness: Implications for global trade policy." Review of International Economics, 9, 317-28.

Maskus, K. (1997), "Should core labor standards be imposed through international trade policy?" Policy Research Working Paper Series 1817, The World Bank.

Sapir, A. (1995), "the interaction between labour standards and international trade." World economy, 18, 791-803.

Srinivasan, T. (1996), "International trade and labour standards from an economic perspective." In Challenges to the new World Trade Organization (P van Dijck and G. Faher, eds.), 219-224, Kluwer Law International, The Hague.

Ulph, A. (1994), "Environmental policy and international trade: a survey of recent economic analysis." Discussion Paper Series In Economics And Econometrics 9423, Economics Division, School of Social Sciences, University of Southampton. 


\section{Chapter 4}

\section{Employment Protection Legislation,}

\section{Trade, and Legal Origins: An Empirical}

\section{Analysis}

\subsection{Introduction}

The relationship between trade and labour standards is a widely debated topic in both the political and academic arena. Trade negotiations between rich and developing countries often elicit strong opinions from lobby groups, activists, and politicians alike with concerns about the exploitation of cheap labour in developing countries on the one end, to the "unfair" competitive advantage of such countries on the other. The latter argument is often based in a fear of the so-called "race-to-the-bottom" (RTB) in labour standards that could arise from increasing economic integration, as countries attempt to gain competitive advantage on international markets by cutting domestic regulations.

As seen in Chapter 3, recent theoretical literature has attempted to model the strategic use of labour standards and a possible RTB resulting from international competitive pressures. On the empirical side, there is little consensus whether there is evidence of a RTB. Empirical analyses are often limited by data availability on labour 
standards, and this has impacted findings emerging from these works. Most studies have focused on the impact of labour standards put forth in the 1998 ILO Declaration on the Fundamental Principles and Rights at Work, with stipulations requiring the improvement of freedom of association and collective bargaining (FACB) rights, the abolition of forced and child labour, and non-discrimination. These are often referred to as "core labour standards", and as such, studies of this nature have tended focus to on North-South trade.

It is important to point out, however, that simple ratification of the Declaration does not imply enforcement of labour standards. Often, poorer countries lack the institutional resources for enforcement. Furthermore, while many have focused on the impact of labour standards on trade, an equally worthy question is whether trade impacts labour standards. This is important in light of the growing trend towards labour standard provisions in preferential trade agreements (World of Work Report, 2009). Thus, it is entirely possible that labour standards are endogenous to trade.

While core labour standards are often the focus of research in this area, we may think of standards more broadly. Labour standards either improve working conditions (i.e., occupational safety) or compensation for work (i.e., wages or benefits). The latter could include benefits such as employment protection - that is, notice periods following dismissal, severance pay, or unemployment benefits. In the trade and labour standards literature, these kinds of "standards" are not often addressed, and are more relevant if we are considering trade with developed countries.

In the area of law and economics, while not addressing trade or a RTB explicitly, seminal research has shown that labour protection differs by a country's legal origin. In particular, this literature has argued that the legal tradition of a country shapes its approach to regulation, with countries of Common Law origins having a more flexible approach to labour regulation compared to those of Civil Law origins. A number of important papers in this literature have shown that employment protection, for 
example, differs in this way (Botero et al. (2004)). This literature is also related to the broader area of new institutional economics, where, for example, there is considerable work suggesting that colonial history has economic consequences in present times via its impact on institutions (Acemoglu 2001, 2005). Thus, labour institutions such as legal frameworks are themselves framed by colonial and legal histories. Given that a country's approach to employment protection can differ by legal origin, we may ask the question of whether the impact of trade on employment protection will also thus differ.

The goal of this chapter is to examine the impact of trade on employment protection, bridging these two strands of literature on trade and labour standards and legal origins. By bringing in legal origin theory, I am able to address the question of not only whether trade impacts labour standards, but whether this impact differs by legal origin. To the best of my knowledge, this has not been done before, and is thus one contribution of this chapter. A further contribution of the chapter is the use of a broader definition of labour standards; specifically, I look at the length of notice periods employers are required to give employees who are being dismissed. Since this requirement varies by the length of an employee's tenure, I also consider notice periods for employee dismissals after nine months, four years and 20 years of service. The empirical analysis is conducted for a cross-section of 72 countries over two different time intervals, using a new dataset (2010) on structural reforms of 90 countries from the Fondazione Rodolfo Debenedetti ( $\mathrm{fRDB}$ ), as well as alternative classifications of legal origins. I also use two alternative measures of notice periods, which necessitate two different estimating models - a Tobit model and an ordered probit model.

The paper is organized as follows. Section 2 reviews the relevant empirical literature on trade and labour standards and legal origin theory. Section 4.3 presents the empirical model, data sources, and estimation methodology. Results are presented in Section 4.4, followed by an extension in Section 4.5. Section 4.6 concludes the paper. 
All figures and tables are found in the Appendix at the end of the chapter.

\subsection{Literature Review}

\subsubsection{Trade and Labour Standards}

Empirical work on the relationship between trade and labour standards is relatively new, largely due to the lack of reliable data on "labour standards" until recent years. A large part of the literature focuses on the impact of labour standards on trade, while few studies have treated labour standards as endogenous to trade. The results of this literature are mixed, and tend to vary due to differing interpretations and measurement of labour standards.

\section{The Impact of Labour Standards on Trade}

While the concern about the RTB in labour standards has primarily focused on NorthSouth trade, this is not to discount the potential effects of standards on trade among developed countries, which are among themselves a heterogeneous group. Much of the existing literature has studied how labour standards (defined in some way) impacts on trade. Van Beers (1998), for example, uses a gravity model to study the effect of labour standard stringency on bilateral trade flows for a sample of 18 OECD countries. The author departs from traditional analyses of core labour standards and constructs outcome-based labour stringency indices to empirically examine whether high-stringency OECD countries exhibit lower exports in labour-intensive goods than countries with lower labour standard stringency. The paper applies OLS to a gravity equation with seven different measures of trade flows as the dependent variable, the first being total bilateral trade flows. Subsequent measures decompose exports by skill level and labour/capital intensity. Results point to a slight negative and 
significant impact of domestic labour standard stringency on high-skilled capitalintensive bilateral trade flows, while the impact is positive and significant for their low-skilled counterparts. The results a negative impact on high-skilled but labourintensive goods.

In a similar vein, Dehejia and Samy (2011) use a gravity trade model for 13 European Union countries over four years. Relative labour standards are introduced in the standard gravity equation to estimate their impact on exports of manufactured goods, high technology manufactures (i.e., high-skilled and capital-intensive), and low technology manufactures exports (low-skilled, labour-intensive). Six different measures of labour standards are added respectively to the baseline model, including the total public expenditure share of GDP, an index of labour market well-being, actual weekly hours worked, trade union density rates, the number of strikes and lock-outs, and occupational injuries. To capture the potential effects of economic integration, the authors include a dummy variable indicating membership in the EFTA, another for whether a country is a member of the EC, and a dummy indicating whether a country has adopted the Euro. Overall, pooled OLS results point to an association between improved export performance and lower labour standards when the occupational injuries variable is used. Most of the other labour standard variables go against the conventional wisdom. These results persist when the authors used Fixed Effects (FE) estimation, when the dependent variable is restricted to labour-intensive goods, and a series of robustness checks.

In another study, Dehejia and Samy (2008) empirically examine the effects of standards on trade sample of EU countries in a Heckscher-Ohlin framework. For a panel of 16 countries over the years 1980 to 2001, the authors specify the dependent variable as manufactured exports of EU countries to the rest of the world, within the EU, and labour-intensive manufactured goods respectively. The same labour standard indicators as in the authors' 2011 paper are used. Fixed Effects (FE) and 
Random Effects (RE) results point to a negative effect of public social expenditure and trade union density on total exports from the EU to the rest of the world. This is taken to imply that labour standard improvements deteriorate exports. In the case of manufactured exports within the EU, results point to positive impacts of labour market well-being, public social expenditure, and weekly hours worked. When the authors focus on labour-intensive exports, RE estimation indicates a positive effect of unionization and public social expenditure on exports. In an extension, the authors add lagged exports to account for the possibility of a dynamic relationship. Difference GMM results point to little evidence of a negative impact of standards on exports, with some evidence of positive effects.

Following Dehejia and Samy $(2008,2011)$, Bonnal (2010) examines the impact of work injuries and the rate of strikes or lock-outs on export performance. Unique to this analysis, however, is that Bonnal pursues a dynamic panel approach more thoroughly. The dependent variable measuring export performance is the ratio of exports to GDP, and to account for possible persistence in trade, a lagged dependent variable is introduced. Control variables include measures for comparative advantage, population density, GDP per capita, and health conditions. To account for the possibility of institutions facilitating trade, institutional quality variables are also included. As in Dehejia and Samy $(2008,2011)$, work injuries and the rate of strikes or lock-outs are used to measure labour standards in a country. The author uses the Difference GMM estimator to account for the dynamic nature of the model, and to also account for the endogeneity of labour standards. Results point to labour standards actually improving export performance. These findings are robust to a number of specifications. Institutions also promote trade, and the author points to the joint roles of standards and institutions in improving export performance. 


\section{The Impact of Trade on Labour Standards}

As countries become more open and integrated with others through international trade, one would expect that pressures of international competition could weaken labour standards in order to maintain competitiveness, even without there being a race-to-the-bottom in standards. On the other hand, increased openness would also create domestic pressures by labour groups most impacted by international competition to press for tighter standards; for example, those representing workers in import competing sectors, especially since they are more likely to be in the formal sector rather than the non-tradeable informal sector that is often not covered by employment protection legislation. Thus, labour standards might become stricter or weaker, or not change at all; much would depend upon the type of labour standard, the extent to which trade is between countries with different standards to begin with, as well as the flexibility of the overall regulatory framework.

In the empirical literature, traditionally there has been a focus on core labour standards, particularly in the context of North-South trade (see Mah (1997), Busse $(2002,2004)$, Kucera and Sarna (2006), or Neumayer and De Soysa (2006) for example). A few of these authors have treated labour standards as the dependent variable and I focus on these in this section. Neumayer and De Soysa (2006) reverse the model in Kucera and Sarna (2006), treating FACB rights violations as the dependent variable. They suggest that greater international integration leads to fewer violations. The authors use OLS as a first look at the relationship, and expand the analysis to take into account the endogeneity of some key explanatory variables like trade openness. Among other traditional explanatory variables, the authors also include indicators for the kind of legal system in place. Initial results for OLS and instrumental variables estimation for a sample of 139 developing and developed countries show that greater trade openness is associated with lower FACB rights violations. In 
a restricted sample of only developing countries, the authors get similar results.

Akin to Neumayer and De Soysa (2006), Busse (2004) assesses the impact of trade openness on labour standards for a sample of developing countries. The author use three core labour standard outcomes as dependent variables - forced labour and union rights, discrimination, and child labour. When regional dummy variables are included, OLS regressions suggest that trade openness promotes gender equality, and reduces child labour. An extension using fixed effects estimation leads to mixed results. However, once trade is introduced as a lagged variable, positive and significant effects are repeated for discrimination and child labour.

Edmonds and Pavcnik (2006) empirically examine the impact of trade openness on child labour prevalence in developing and developed countries. Initial estimates suggest that greater openness is associated with less child labour, however, the authors argue that this reflects income effects. When cross-country differences in income are accounted for, the authors find no significant impact of trade openness on child labour. The same story emerges when the authors account for potential endogeneity of income, restrict the sample to non-OECD countries, or when trade openness is measured as unskilled, labour-intensive exports relative to GDP.

A recent study by Jansen et al. (2012) also take advantage of the fRDB's 2010 dataset on structural reforms. The authors attempt to analyze how labour protection responds to trade within regional trade agreements (RTAs). Using the full panel of 90 countries over 1980 to 2005 , the authors treat labour protection as the dependent variable. Labour protection is measured by advanced notice periods of dismissal, severance pay, and gross replacement ratios of unemployment benefits for different levels of tenure. The authors develop a proxy for RTA trade that, for each year, essentially captures a country's exports to countries with which there is a signed RTA as a share of total exports in that country, weighted by a dummy capturing 
whether that country had any RTA in force at the beginning of that year. ${ }^{1}$ Treating RTA trade as a lagged variable, Fixed Effects and Random Effects regressions show a negative and significant impact of RTA trade on notice periods after nine months of service, severance pay after 20 years of service, and gross replacement ratios after one year of service. When the analysis is broken down by income group, this result only holds for high income countries.

\subsubsection{Legal Origins and Labour Regulation}

The research on legal origins fits into the larger literature on institutional economics that suggests that institutions are dependent on a country's history. ${ }^{2}$ In a series of seminal papers, La Porta et al. (1997, 1998, 1999) (henceforth, La Porta) contend that legal traditions shape a country's approach to regulation. The authors focus on the two main legal traditions, Common Law and Civil Law, and a few traditions within Civil Law - French, Socialist, Scandinavian, and German. Legal theory, as the authors argue, contends that countries of Civil Law origin tend to rely more on regulation and state ownership, while those of Common Law origin will favour markets and contracts. As such, the regulatory-style of a country should reflect this. In their 1997 and 1998 papers on law and finance, La Porta et al. show that systematic differences in the stringency of investor protection across countries could be attributable to a country's legal history, with countries of Common Law origin offering more protection of outside investors than those of Civil Law origins, thereby promoting greater financial development in the former. In this vein, the authors broaden their analysis to address the quality of government and legal origins in their 1999 paper. The authors use legal origins as proxies for the political orientation of

\footnotetext{
${ }^{1}$ The authors take bilateral export data for every country in the sample, and calculate the following for each year, $t: \sum_{j} R T A_{i j t} \times$ Exports $_{i j t} /$ Exports $_{i t}$, where RTA is a dummy variable indicating whether country $i$ had an RTA with country $j$ in that year.

${ }^{2}$ See Acemoglu et al. (2001) or Acemoglu (2005) for example.
} 
government, showing that countries of Civil Law origin have more interventionist policies than Common Law ones.

The result that legal origins could shape regulatory styles led to an explosion of literature on the role of legal history in shaping other regulations and their economic consequences. Notably, using the legal origin classification developed by La Porta , Botero et al. (2004) argue that labour regulation, or the extent to which governments intervene in labour markets, differs by legal origin, with countries of Civil Law origins having more stringent approaches to labour protection than countries of Common Law traditions. The authors construct labour protection indices for a sample of 85 countries, capturing the stringency/flexibility of employment, collective relations, and social security laws. Simple OLS regressions show that countries of Civil Law origin have greater employment law stringency than Common Law countries, with these differences remaining large for all sub-traditions (French, Socialist, Scandinavian, and German). This result is also reflected for collective relations laws. In terms of social protection, results are similar except for countries of German legal origin, who do not show greater stringency compared to Common Law ones.

Campos and Nugent (2012) expand on Botero et al. (2004) by attempting to construct a comprehensive labour regulation index for over 100 countries. Exploiting the NATLEX database on labour laws from the International Labour Organization, the authors focus on conditions of work, employment security, termination of employment, conditions of employment (i.e., contracts or wages) and general provisions for five year intervals over the 1960-2005 time-period. Higher values on the single constructed index reflect more rigid employment protection laws. Benefiting from a relatively long panel, the authors examine changes in the index over time in a dynamic panel model to assess labour market reforms. They include various trade liberalization variables to determine whether other kinds of reforms also impact labour reforms. Overall, Dynamic GMM regressions point to little evidence that legal origins 
matter for labour reforms. Trade openness is found to positively impact changes in the labour regulation index, while an increase in the black market premium reduces these reforms. The authors argue that trade liberalization thus slows down changes in labour market regulations.

Aside from Campos and Nugent (2012) who look at the independent effect of trade liberalization, Flanagan (2006) also augments the Botero et al. (2004) regressions with a trade openness measure (i.e., trade share of GDP). The author finds no significant relationship between openness and the labour regulation measures. Note, however, none of these studies address the question of whether trade effects differ by legal origin.

An assumption in this literature is that a country's legal tradition either develops endogenously (i.e., Common Law in England), or is "transplanted" - that is, implemented as a result of colonialization (i.e, Common Law in India). Note, however, some countries have had more than one colonizer throughout history, and could have legal traditions representing a mixed colonial history. ${ }^{3}$ While not addressing regulation, in a very recent paper, Klerman et al. (2011) argue that colonial origins matter in the classification of legal origins, with the possibility "hybrid" traditions. The authors adjust the La Porta classification of legal origin to account for colonial history in a more nuanced way. In particular, countries that would be considered of Socialist origins in the La Porta classification are re-classified to their pre-U.S.S.R. origins, which were largely French or German Civil Law. A "Mixed" category is introduced to account for hybrid legal traditions arising from a mixed colonial history, a category that would otherwise be considered pure Common Law origins in the La Porta classification. Overall, the authors make the argument that legal origins need to be

\footnotetext{
${ }^{3}$ There are some British colonies that we could consider in this mixed or hybrid category. For example, South Africa and Sri Lanka were originally colonized by the Dutch and subsequently the British in the late 18th century. As such, these countries had elements of Civil Law before being influenced by Common Law.
} 
taken together with colonial history in analyses addressing institutions and growth.

Given that a country's approach to labour regulation (or more generally, labour market institutions) varies by legal history, it is possible that the impact of trade on labour standards differs by legal origin. The literature suggests that countries of Civil Law origins tend to have greater government intervention in labour markets compared to countries of Common Law traditions. Consequently, if trade has an impact on labour standards, as the empirical trade literature suggests, then it is quite possible that this impact could differ by legal origin. To date, however, this has not been analyzed rigorously in the literature. The next section outlines an empirical approach to analyze this question.

\subsection{The Model, Data and Methodology}

\subsubsection{The Empirical Model}

In the trade and labour standards literature, there is little consensus on the structure of the empirical relationship, largely due to limited data and a lack of definitive theory. The majority of empirical analysis has focused on bilateral trade gravity models augmented with measures of labour standards. This is possible in smaller country samples and becomes more difficult as one moves to larger ones. Furthermore, as seen in the previous section, labour standards have appeared on both the left-hand-side and right-hand-side of the empirical model. This points to a potential endogeneity problem. We have also seen that a significant portion of the literature focuses on core labour standards and working conditions. As in Jansen et al. (2012), recent research has moved from core labour standards due to greater data availability on variables pertaining to employment protection.

The empirical model employed in this paper attempts to bridge research on trade and labour standards with that of legal origin theory. As described in the previous 
section, the main empirical models in the legal origins literature tend to rely on author-constructed indices of labour regulation that serve as the dependent variable, regressed on a series of controls and legal origin dummies. While Campos and Nugent (2012) are able to benefit from a relatively longer panel, longer time series are harder to find in labour standards data. In this paper, due to the slow-changing nature of labour standards, analysis is confined to cross-sectional empirical models. The baseline model takes the following form:

$$
L_{i}=\alpha_{0}+\alpha_{1} T R_{i, t-1}+L O_{i} \alpha_{2}+X_{i} \alpha_{3}+\epsilon_{i}
$$

In equation (4.1), $L_{i}$ is a measure of a particular labour standard for country $i, T R_{i, t-1}$ is a measure of trade openness for country $i$ in the previous period, $L O_{i}$ is a vector of dummy variable indicating the legal origin of country $i$ (discussed in the next section). The vector $\boldsymbol{X}_{\boldsymbol{i}}$ contains control variables and $\epsilon_{i}$ is the error term. Note that the trade term is lagged one period. This is to account for the slow-changing nature or rigidity of labour standards - that is, it is likely that if trade has an impact on labour standards, it is a delayed one and not simultaneous. This is even more likely given that many standards pertaining to labour protection are legislated, and thus changes would require the introduction of or changes to labour protection laws. An extended benefit of lagging the trade variable (that is, making it a pre-determined variable), is that this also deals with the possible simultaneity of the trade-labour standards relationship.

Following the literature on legal origins, dummy variables are included to capture the idea that a country's current approach to labour regulation is a product of its legal tradition and history. If the regulatory environment is a product of its legal tradition, it is possible that the impact of trade on labour standards may also differ according to legal origin. For example, Botero et al. (2004) argue that countries 
with French Civil Law origins tend to have more regulation. Thus, labour standards could be slower to change in such countries where there are more laws, compared to say, Common Law origin countries. It follows that the impact of trade on labour standards could vary by legal tradition. Based on this line of reasoning and existing literature, equation (4.1) is expanded to include legal origin and trade interaction terms:

$$
L_{i}=\beta_{0}+\beta_{1} T R_{i, t-1}+L O_{i} \beta_{2}+L O_{i} T R_{i, t-1} \beta_{3}+X_{i} \beta_{4}+\mu_{i}
$$

The empirical analysis is based on equation (4.1). If the impact of trade on labour standards differs by legal origin, the coefficients on the interaction terms should be significant.

\subsubsection{Data and Measurement}

Following Jansen et al. (2012), and keeping in line with the legal origin literature, this chapter does not focus on core labour standards but rather employment protection legislation. This is particularly important in light of the fact that most labour provisions in trade agreements are imposed by developed countries. Also, by moving away from core labour standards, we are able to move from an ethical argument to an economic one. That is, whether employment protection is strong or weak does not directly translate into an interpretation of good or poor labour standards. Optimal labour protection would require balancing protecting workers and providing employers the flexibility of adjusting to market conditions - thus very stringent labour laws could benefit workers but harm producers, while very weak laws could harm workers but benefit producers.

The focus of this chapter is on an important component of employment protection - notice periods employers are required by law to give workers that are being 
dismissed. Thanks to a recent dataset from the Fondazione Rodolfo Debenedetti (fRDB), data on notice periods is available (in months) for employment tenures of nine months, four, and 20 years for 90 countries from 1980 to 2005 . While comprehensive indices are helpful for providing an overall picture of the state of labour protection, using notice periods allows for a more focused analysis. Thus, notice periods serve as the dependent variable in equation (4.2). ${ }^{4}$ Note that countries covered in the sample are listed in Table 4.1 of the Appendix.

As an additional measure of $L_{i}$, I code raw notice periods according to the OECD coding methodology on the strictness of employment protection legislation (OECD, 2004). This methodology scales the raw measures from zero to six with higher values on the scale representing more stringent notice periods. Due to the size of the sample, I simplify this score further so that it lies on a scale from zero to three. This score on notice periods is used as a secondary measure of the dependent variable such that $L_{i} \in\{0,1,2,3\}$.

Measuring trade openness or trade policy orientation is a contentious topic and has been hotly debated among economists. In this analysis, the depth of international integration of an economy is proxied using the well-known trade ratio measure, $\frac{X+M}{G D P}$, which is simply the share of total trade in GDP. Like most related measures, the trade share has its drawbacks, in that these shares are also driven by country size, and may not fully capture trade policy orientation. However, the measure is commonly used in the general empirical literature, as well as in the trade and labour standards literature. $^{5}$

\footnotetext{
${ }^{4}$ Note that employment protection in this dataset is a law-based measure as opposed to an outcome-based one. While the latter would have been a useful comparison to the law-based measure, these data are simply not available.

${ }^{5}$ While beyond the scope of the current paper, a useful extension would be to test the robustness of the results with alternative specifications of trade integration. For example, a measure that captures a country's policy orientation more directly would be particularly interesting.
} 
Control variables are all drawn from the World Bank's World Development Indicators and include real GDP per capita and its square (both in logs) to capture the level of development, and the share of employment in agriculture in total employment to account for the employment structure of the economy. Including the level of the development is standard in both the trade and labour standards literature and that of legal origins. Typically, authors argue that as the level of development increases, a country's labour standards improve but at a decreasing rate. In the case of employment protection, the impact is less clear. A common view is that institutions in general are created to correct for market failures, implying that richer countries should have less regulation because they have fewer market failures - an efficiency market argument. However, Botero et al. (2004) refute this with evidence suggesting that richer countries have more generous social security systems for example. Similarly, some have argued that labour standards can be treated as normal goods, thus as countries get richer, they demand stronger standards. With employment protection, however, this argument is less clear. Thus, there is no a priori anticipated impact of the level of development.

Legal origin dummies follow the La Porta et al. (1999) classification and are available from the Quality of Government (QoG) Dataset assembled by The Quality of Government Institute at The University of Gothenburg (henceforth the "La Porta classification"). Legal origin dummies in equation (4.2) contain indicators for English Common Law, Socialist Origins, and an Other category which accounts for Scandinavian or German code. The base case is French Civil Law. As established in the literature review, research suggests that countries with a legal tradition based on Common Law tend to have more market-oriented laws than those countries with a history of French Civil Law (La Porta et al., 2008). As such, this would suggest that Common Law countries would have more flexible employment protection compared to countries of French Civil Law origin (Botero et al., 2004). Thus, the coefficient on 
the Common Law dummy variable could possibly be negative. Conversely, countries based on Socialist origins or Scandinavian/German code tend to have more stringent regulation and therefore employment protection could also be stronger in these countries. Such an impact would be reflected in a positive coefficient. In any case, evidence of a differing impact of trade by legal origins on notice periods would be reflected by significant coefficients on the interaction terms.

Using data from Klerman et al. (2011), I also adopt an alternate classification of legal origins as a robustness check (henceforth the "Klerman classification"). As mentioned, this classification accounts for former colonies that subsequently adopted different legal frameworks or have a mixed colonial heritage. Note also that the Klerman classification does not differentiate Socialist origin countries (i.e. former Soviet Union and those countries affected by its armies) as in the La Porta classification, but categorizes these countries based on their pre-Communist legal systems which were largely of French or German Civil Law origin. Thus, legal origin dummy variables include Common Law, Mixed, and Other (Scandinavian/German) origin. As before, the base case is French Civil Law origins (Table 4.2 in the Appendix shows the country breakdown for each classification). In terms of predicted impacts, there is no prior research assessing the relative stringency of labour regulation in Mixed legal origin countries. It is possible that the direction of the impact will depend on which colonial history had the most influence in shaping the legal system and institutions of such countries. Nevertheless, a significant effect, regardless of the direction, will at least indicate a differing impact.

The corresponding interaction terms in equation (4.2) are constructed given these measures of legal origin and trade. It is anticipated that the impact of trade on notice periods will differ by legal origin. Since Common Law origin countries have been found to have more flexible regulation, it is anticipated that trade would have a non-zero impact in these countries. Socialist and Scandinavian/German legal origins 
tend to have similar approaches to regulation as countries with legal traditions based in Civil Law. As such, we would anticipate that these countries have more stringent employment protection and given their tendency for more regulation. There are two possible impacts of trade on employment protection in these types of countries. On the one hand, we might expect that since countries with more stringent employment protection are less flexible to changing economic conditions, trade would not have an impact. Note, however, that higher employment protection (reflected in longer notice periods in this paper) also reflects a labour policy-orientation that is more worker-focused. It is possible, then, that in the presence of international competitive pressures, countries that are more worker-oriented in their labour policies may have the incentive to enhance labour regulation (i.e., make it harder for firms to fire workers quickly). In this case, the interaction term for Socialist or Scandinavian/German civil code would have a positive impact.

\subsubsection{Estimation Methodology}

Due to the slow-moving nature of employment protection regulation and data limitations, I focus on cross-sections estimated at different points in time. ${ }^{6}$ Data are averaged over five years so as to ensure that we are not capturing any macroeconomic shocks or atypical years. I focus on the 1990-1995 and 2000-2005 time periods in two separate cross-sectional regressions.

With raw notice periods as the dependent variable, equation (4.2) can be estimated using a Tobit model. This procedure is useful in that notice periods often take on a value of zero and we are in a scenario that may be interpreted as a corner solution. That is, all data are observable and a notice period of zero has economic

\footnotetext{
${ }^{6}$ Though Jansen et al. (2012) used Fixed Effects panel estimation on the same dataset, the majority of the variation is cross-sectional and not over time. As such, FE regressions on very persistent data is an inappropriate approach and there is little additional information to be attained by using panel data techniques. A much longer time series would be required to do so.
} 
meaning (no employment protection). Under these circumstances, the OLS method is inappropriate in that the estimators can be shown to be inconsistent. The use of a Tobit model over a count model (such as the Poisson model) is predicated on the fact that count models are suitable for dependent variables that take on integer values. Raw notice periods do not have this characteristic, rather, they represent more clearly a censored distribution. That is, there many limit observations (i.e. taking on a value of zero), combined with non-zero observations which are, in principle, continuous. Thus, re-expressed as a Tobit Model, equation (4.2) becomes:

$$
\begin{aligned}
L_{i}^{*} & =\beta_{0}+\beta_{1} T R_{i, t-1}+L O_{i} \beta_{2}+L O_{i} T R_{i, t-1} \beta_{3}+X_{i} \beta_{4}+\mu_{i} \\
L_{i} & =L_{i}^{*} \text { if } L_{i}^{*}>0 \\
& =0 \text { otherwise }
\end{aligned}
$$

Where $L_{i}^{*}$ is the unobserved (latent) variable that determines the observed variable, $L_{i}$. It is important to point out, however, that impacts on the latent variable are not particularly useful in the context of this analysis. The results for the observed variable are of more interest - that is, the marginal impacts of the right-hand side variables on observed notice periods, $L_{i}$ :

$$
\frac{\partial E[L \mid z]}{\partial \boldsymbol{z}}=\boldsymbol{\beta} \Phi\left(\frac{\boldsymbol{\beta}^{\prime} \boldsymbol{z}}{\sigma}\right)
$$

Where vector $\boldsymbol{z}$ contains all explanatory variables, $\boldsymbol{\beta}$ contains all coefficient estimates, and $\Phi(\cdot)$ is the cumulative normal distribution function evaluated at particular values of $\boldsymbol{z}$ (typically mean values).

Finally, using constructed scores for notice periods as the dependent variable instead, another angle in the estimation technique is possible. Since the score value itself 
is meaningless but the ranking matters (with higher scores associated with longer notice periods), we may also estimate equation (4.2) using an ordered probit model. The empirical model can be re-expressed to incorporate the latent variable $L_{i}^{*}$ :

$$
\begin{aligned}
& L_{i}=0 \text { if } L_{i}^{*} \leq \nu_{1} \\
& L_{i}=1 \text { if } \nu_{1}<L_{i}^{*} \leq \nu_{2} \\
& L_{i}=2 \text { if } \nu_{2}<L_{i}^{*} \leq \nu_{3} \\
& L_{i}=3 \text { if } L_{i}^{*}>\nu_{3}
\end{aligned}
$$

In the above, the $\nu$ 's are cut-off points that can be estimated along with the coefficients of the model. These indicate levels at which the latent (unobserved) variable moves from one outcome to another. A useful interpretation from the magnitude of these values is the ease/difficulty of moving from a lower level of employment protection to a higher one. For example, if both $\nu_{1}$ and $\nu_{2}$ are closer to each other in magnitude than $\nu_{2}$ and $\nu_{3}$, this would suggest that it is easier to strengthen employment protection when starting from lower protection.

Again, coefficients from ordered probits are relatively meaningless in their raw form. Of more interest is the probability of attaining a particular notice period score. In general, the probability of each outcome is as follows:

$$
\begin{aligned}
& \operatorname{Prob}(\mathrm{L}=0)=\Phi\left(\nu_{1}-\boldsymbol{\beta}^{\prime} \boldsymbol{z}\right) \\
& \operatorname{Prob}(\mathrm{L}=1)=\Phi\left(\nu_{2}-\boldsymbol{\beta}^{\prime} \boldsymbol{z}\right)-\Phi\left(\nu_{1}-\boldsymbol{\beta}^{\prime} \boldsymbol{z}\right) \\
& \operatorname{Prob}(\mathrm{L}=2)=\Phi\left(\nu_{3}-\boldsymbol{\beta}^{\prime} \boldsymbol{z}\right)-\Phi\left(\nu_{2}-\boldsymbol{\beta}^{\prime} \boldsymbol{z}\right) \\
& \operatorname{Prob}(\mathrm{L}=3)=1-\Phi\left(\nu_{3}-\boldsymbol{\beta}^{\prime} \boldsymbol{z}\right)
\end{aligned}
$$


Accordingly, by setting the independent variables at particular values, we can calculate predicted probabilities of obtaining each score level of the dependent variable. Furthermore, we can look at how these probabilities change by legal origin and by legal origin and trade openness.

\subsection{Results}

Before turning to the regression results, summary statistics of notice periods are available in Table 4.3 of the Appendix. Recall that variables are measured by five year averages and we focus on the 1990-1995 and 2000-2005 time periods. It can be seen that notice periods increase with length of tenure, in both time intervals. For instance, in the 1990-1995 interval, a worker with 20 years of service requires an average advance notice period of 1.86 months compared to only 0.82 months for a new worker (that is, one who have been in service for only 9 months). Of course, the range of variation in notice periods can be quite large. In particular, the notice period varies from a low of zero months to just under 9.5 months for those who have been in service for 20 years. As well, employment protection, in terms of the average length of notice periods, shows an increase between 1990-1995 and 2000-2005, for each length of tenure, albeit by relatively modest amounts. The picture is similar if we look at the OECD scores on notice periods, with one exception - workers with four years of service have less protection (on average) than those with only nine months of service in both time intervals. Of course, this could be due to sampling error.

The trade openness variable shows patterns one would expect, with increasing values between 1990-1995 and 2000-2005, which point greater economic integration and openness of the economies in our sample. There is also considerable cross-country variation, with trade shares being in the 15-23 percent range at the low end (Argentina and Japan), and the 158-206 percent range at the high end (Malaysia) over the two 
time intervals. Real GDP per capita growth averages about 20 percent between the two time intervals.

Table 4.4 shows how notice periods (in 2000-2005) vary over legal histories. For both raw notice periods and scores, we see that countries of French Civil Law origin tend to have higher values compared to Common Law countries, except for when workers have 20 years of service. This holds when we look at the Klerman classification as well. Not surprisingly, countries of Socialist or Scandinavian/German legal origin tend to have longer advanced notice period compared to French Civil or Common Law origin countries. Using the Klerman classification, we see also that countries of Mixed legal origin have longer notice periods than Common Law origin countries, except for those workers with 20 years of experience. In general, countries of Mixed legal origin tend to exhibit values similar to countries of purely French civil law origin.

\subsubsection{Tobit Regression Results}

Table 4.5 in the Appendix presents Tobit results of equation (4.2) using the La Porta classification of legal origins. Regressions for notice periods at nine months and four years of service respectively perform poorly overall, with many insignificant coefficients. For notice periods at 20 years of service, GDP per capita has a negative and significant impact, while its square is positive and significant. This indicates that richer countries tend to have shorter notice periods, but this effect diminishes as GDP per capita rises. Note also that the lagged trade share has a positive and significant impact on notice periods, indicating a move to more stringent employment protection with greater trade integration. Overall, however, notice periods and trade impacts do not differ significantly by legal origin, and the agricultural share of the economy does not seem to matter.

To account for the possibility that legal origins are themselves shaped by colonial 
origins, Table 4.6 contains Tobit regression results for equation (4.2) using the Klerman classification of legal origin. It is immediately clear that there are many more significant coefficients across equations and time periods. Increasing GDP per capita decreases notice periods for notice periods after 20 years of service in the 1990-1995 regression, but at a decreasing rate. This effect disappears in the 2000-2005 regression. The agricultural share of the economy continues to have little impact on notice periods. A major difference, however, that legal origins matter. For instance, in the 1990-1995 period, countries of mixed legal origin have significantly higher notice periods than the base case (French Civil Law).The effects of other legal origins are somewhat mixed across lengths of employee service. The trade coefficient is positive and statistically significant in all regressions, but the negative and significant coefficient on interaction terms in all but a few regressions, suggests that this impact declines the greater the degree of openness.

Raw coefficients from Tobit regressions only show the marginal impact of each independent variable on the latent (unobserved) dependent variable. As mentioned in Section 4.3.3, these coefficients can be transformed to capture the marginal impact on actual (observed) notice periods. Tables 4.7 and 4.8 thus show the estimated marginal effects for the La Porta and Klerman classification respectively. In examining the marginal effects on notice periods of trade and legal origins, we can look at two types of effects. First, the effects of increased openness if legal origins did not matter, as opposed to a situation where they did. Second, the effects of legal origins if trade openness did not matter versus one where it does. If we assume that trade openness is a measure of the stance of trade policy, the former case looks at the effects of a change in trade policy, given legal origins, while the latter looks at the effects of legal origins for a given trade policy.

Focusing on key results presented in the last paragraph, it can be seen in Table 4.7 that, for the period 1990-1995, a one percentage point increase in the a country's 
trade share increases notice periods at 20 years of service by approximately 0.03 months, independently of legal origins - that is, even if legal origins did not matter. Of course, this is the trade share impact of countries with French Civil law legal origins (the default group), if legal origins do matter. This impact is slightly smaller (0.023) in the 2000-2005 interval. We also see that in 2000-2005, trade share has a statistically significant positive impact on notice periods after nine months of service, though the impact is small (0.006). The lack of statistically significant coefficients on the interaction variables suggest that these trade share impacts are similar across all legal origins.

As far as the impact of legal origins, independently of trade openness, is concerned, the entire set of estimates in Table 4.7 shows that countries with Common law, Socialist, or Scandinavian/German legal origins would have longer notice periods than countries with French Civil law origins. However, the only statistically significant impact is that of countries with Socialist legal origins, which have notice periods (for those with nine months or 4 years of service) that are about 1.2 months greater than those of countries with French Civil Law origins in the 2000-2005 period. The negative coefficients on most interaction terms suggest that these effects of legal origins on notice periods would be positive for only countries that were low on the openness scale, with the impact turning negative for highly open countries. However, given the statistical insignificance of all (but one) interaction variable coefficients, the evidence suggests that the effects of legal origins are independent of the degree of openness of these economies.

Table 4.8 shows the marginal effects based on the Klerman classification of legal origin. Focusing on key results for legal origins, notice periods differ by legal origin over both time periods, independently of the degree of openness. With one exception (tenure of nine months in the 2000-2005 interval), all other estimates suggest that countries with Common Law, Mixed or Scandinavian/German legal origins have 
stricter labour standards in terms of having longer notice periods than countries with French Civil Law origins. Thus, for example, in 1990-1995, countries of Common Law origin have notice periods after 20 years of service that are 1.5 months higher than the base case, though there is no statistically significant impact at lower years of tenure, nor in the 2000-2005 interval. Conversely, Mixed legal origin countries have statistically significant larger notice periods across the board in 1990-1995, ranging from 2.6 months for those in service for nine months to 7.4 months for those with 20 years of service. Note, however, that by $2000-2005$, this impact is only statistically significant for notice periods after 20 years of service.

In addition, since all the interaction terms are mostly negative (and statistically significant), this suggests that the degree of openness modifies the legarorigin impacts. Specifically, for countries that are at the low end of the openness spectrum, the impact of the each of the three legal origins is to make for stricter standards relative to French Civil Law origins, but the opposite is true at high levels of trade openness. For instance, comparing countries with Common Law origins with those with French Civil Law origins, the former have average notice periods (at the 20 years tenure level in 1995-2000), that are about 1.5 months longer, if they were closed economies (with a trade share of zero), but those notice periods would be lower by about 1.3 months for Common law countries if trade openness was high (80 percent). Thus, the impacts can be very different depending upon the extent of trade openness.

Turning to the effect of trade, the trade share coefficient is positive and statistically significant across all regressions, indicating that, independent of legal origins, notice periods increase with openness. Alternatively, since French Civil Law is the default legal origin, the trade share impact is that of countries belonging to this group, when legal origins matter. This would mean that, greater openness in countries with French Civil Law origins would strengthen labour standards via longer notice periods. However, countries with other legal origins do differ from the default case because, given 
the negative and mostly statistically significant coefficients on the interaction terms, we can conclude that the impact of openness is lower for countries with Common Law, Mixed and Scandinavian/German legal origins. Thus, in Common Law legal origin countries, the impact of increased openness on notice periods is reduced from 0.048 months to 0.013 months during the 1990-1995 interval, and to just 0.006 months in 2000-2005, looking at those who have been in service for 20 years. A similar pattern is observed at other levels of tenure, and for Mixed and Scandinavian/German origins; indeed for the latter legal origins, the impact of greater openness is negative in some instances.

Overall, our results from the Tobit regressions suggest that, where legal origins matter, mostly in the regressions based on the Klerman classification, they tend to imply longer notice periods for countries with Scandinavian/German, Mixed or Common Law legal origins relative to countries with French Civil Law origins. However, this impact is not independent of openness; generally, longer notice periods would typically occur at low levels of openness, whereas at high levels of openness, the impact of legal origins could lower notice periods, relative to the default case. That is, labour protection becomes less important when the degree of openness is high. At the same time, the impact of increased trade openness by itself is to increase notice periods in countries with French Civil Law legal origins, although that impact is lower (and even negative) for countries of other legal origins.

\subsubsection{Ordered Probit Results}

Re-interpreting raw notice periods as an OECD score described in Section 4.3.2, equation (4.2) is estimated as an ordered probit. Tables 4.9 and 4.10 present results using the La Porta and Klerman classifications of legal origins respectively. Ordered probit coefficients themselves do not have a useful interpretation, except in a simple two-choice model in which the signs of the coefficients are interpretable as positive or 
negative impacts. In an ordered probit model with more choices, this is not the case; raw results can, however, be used to discuss statistical significance.

Starting with Table 4.9, GDP per capita matters in 1990-1995 for notice periods at 20 years of service, but its coefficient is not statistically significant elsewhere. Socialist legal origin seems to matter in 2000-2005 but not in 1990-2005. Countries of Scandinavian/German legal origin are statistically different than countries of French Civil Law origin for notice periods at nine months of service (in both time periods) but not elsewhere. Trade share coefficients are significant at 20 years of service in both periods, and at nine months of service in 2000-2005. The coefficients of the interaction terms are significant only in the 2000-2005 period for Common Law origins (at four years of service), Socialist origins (at nine months and 20 years of service), and Scandinavian/German origins (at four years of service). In these cases, the impact of legal origins would not be independent of trade openness.

A couple of trends emerge by examining the threshold values in Table $4.9, \nu_{1}-$ $\nu_{3}{ }^{7}$ Comparing $\nu_{1} / \nu_{2}$ to $\nu_{2} / \nu_{3}$ is of particular interest since, respectively, these are indicative of the ease/difficulty of increasing notice periods when they are already low versus when they are already high. The closer these ratios are to unity, the greater the ease in moving to a higher score on the stringency index. Firstly, we see an overall trend that, regardless of time period, it is easier to increase notice periods when they are already relatively low after nine months of service compared to four or 20 years of service. Note, however, that the difficulty of increasing notice periods when they are already high is relatively the same for all level of tenure.

Table 4.10 presents ordered probit results for when the Klerman classification of legal origin is used. Again, compared to the La Porta classification, the Klerman classification results in many more significant coefficients. Real GDP per capita (and

\footnotetext{
${ }^{7}$ While not reported in the table, additional tests have shown that each threshold is significantly different from each other.
} 
its square) matter for notice periods at 20 years of service, and only for 1990-1995. Similarly, Common Law legal origin only matters for notice periods after 20 years of service in 1990-1005. Mixed legal origin is statistically significant across all lengths of employee service in 1990-1995, but only at 20 years of service in 2000-2005. The trade share variable is significant in regressions at nine months and 20 years of service in 1990-1995 and at four and 20 years of service in 2000-2005. The coefficients of interaction terms are significant for all three legal origins in one or both periods, at one or more tenures of employee service. For instance, for Common Law legal origins, this happens at nine months and 20 years of service in 1990-1995, and at nine months of service only in 2000-2005, while the same is true for Scandinavian/German legal origins at nine months and 20 years of service in both periods.

Threshold values indicate a similar trend as before. Regardless of the time period, it is easier to increase the notice periods score after nine months of service when starting from lower values. Conversely, moving up the stringency index is more difficult for notice periods after 20 years of service (regardless of the time period), as indicated by the higher ratios. Furthermore, increasing stringency is more difficult for notice periods after nine months and 20 years of service compared to notice periods after four years of service, over both time periods. Additionally, $\nu_{1} / \nu_{3}$ is relatively larger for notice periods after 20 years of service, indicating that it is particularly difficult to move from a low level on the stringency index to a high one.

\section{Predicted Probabilities by Legal Origin}

As mentioned, since ordered probit results themselves tell us little about the relationship between trade, legal origins, and notice periods, it is useful to identify interesting cases that would highlight this relationship by calculating predicted probabilities. As a first pass, we may look at the impact of legal origins themselves. Holding all other variables at their means, Tables 4.11 and 4.12 show the predicted 
probability for each outcome of the dependent variable (scores for notice periods after nine months, 4 and 20 years of service) by legal origin. ${ }^{8}$

\section{La Porta Classification}

Starting with Table 4.11 and looking at the 1990-1995 time period and looking at notice periods after nine months of service, countries of French Civil or Common Law origin are clearly less likely to have stricter labour standards (that is, longer notice periods), compared to the other legal traditions. Thus, these countries have predicted probabilities of 0.50 and 0.52 of being in the top two categories $(L=1$, 2), compared to 0.75 for countries with Socialist legal origins and 0.95 for those of Scandinavian/German legal origins. By 2000-20005, all groups move towards higher probabilities of stricter standards, although the pattern is similar to that found in 1995-2000.

In this regard, the pattern for countries of Socialist origins is interesting. These countries appear to be relatively flexible in terms of notice periods in 1990-1995, but by $2000-2005$, they move to significantly tighter labour standards, as they are most likely to have the highest score $(L=3)$ on the stringency index (a 96 percent predicted probability). This may seem surprising given that most of these countries are post-Soviet nations that actually experienced liberalization of employment protection legislation following the dismantling of Socialist systems. It is important to point out, however, that notice periods were not even included in the Soviet labour code. Thus, while countries of the former U.S.S.R. showed stringency in other areas of employment protection, they showed considerable flexibility in terms of firing costs (Muravyev, 2010). By 2000-2005, however, many of these countries saw large

\footnotetext{
${ }^{8}$ All continuous variables are set at their sample mean, and dummy variables are set to either 1 or 0 depending on the legal origin in question.
} 
increases in notice periods with the introduction of legislation. Georgia, for example, went from having no provisions, to introducing notice period legislation in 1997. Overall, it is clear that countries of Socialist or Scandinavian/German legal origin are predicted to be more stringent in terms of notice periods than those of French Civil or Common Law legal traditions.

Looking at service periods of four and 20 years, it is clear that there is a strong movement towards lower labour standards, in both periods. Regardless of legal origin, the predicted probability of belonging to the two lowest categories on the stringency scale $(L=0,1)$, rises substantially as the length of employment service increases. Looking first at four years of service, countries of French Civil and Common Law legal origin are more likely to have low notice period scores, indicating greater flexibility in labour standards. Thus, during both periods, these groups of countries are, respectively, about 69-71 and 84-90 percent likely to fall in the lowest two categories of notice period scores $(\mathrm{L}=0$ and $\mathrm{L}=1)$. At the same time, countries of Scandinavian/German legal traditions are now also more likely to have lower outcomes, with a predicted probability in the $89-95$ percent range of being in these two categories in both time periods. This indicates that while these countries tend to have more stringent notice periods after nine months of service, they have more flexible notice periods for workers with longer tenure. The case of countries of the Socialist code is qualitatively similar (a move to looser standards) in both periods, but these countries are least likely among the comparison group to be at the lower end of labour standards stringency

Looking finally at notice periods after 20 years of service, the shift towards looser standards intensifies across all countries, except those with Scandinavian/German legal origins. This shift is most significant in countries with the Socialist code, but the probabilities suggest the shifts are far less dramatic in the 2000-2005 period compared to the 1995-2000 period. Countries of Socialist legal origins move from 
having relatively flexible (low) notice periods in 1990-1995 to having much more stringent (high) ones in 2000-2005. This suggests that most countries, regardless of legal origin, appear to be able or willing to adopt to stricter labour standards only for employees who have in service for a short time (that is, less than four years).

\section{Klerman Classification}

Table 4.12 repeats the above exercise using the Klerman classification of legal origin. Although there are differences in absolute probabilities across tenure length and time period, there are, qualitatively speaking, some very similar patterns. Thus, for countries of Common Law and French Civil law origins, there is a clear decrease in the incidence of more stringent notice periods as one moves from nine months, to four years to 20 years of service, in both the 1995-2000 and 2000-2005 intervals. In fact, for countries with French Civil Law legal origins, the absolute probabilities of being in the top two categories, $L=2$ and $L=3$, (the strictest in terms of notice period lengths), are very similar across both periods. The Scandinavian/German legal origins countries also show the same patterns as observed in Table 4.11, and the absolute probabilities of $\mathrm{L}=2$ and $\mathrm{L}=3$ are quite similar at nine months in both periods, and at 20 years of service in 2000-2005. There are, nonetheless some notable changes. For instance, The Common Law legal origins countries are clearly seen to have more stringent notice periods compared to those in Table 4.11. This is generally true across tenure length and time period. At the same time, the Klerman classification points to a clear shift to looser standards for this group of countries, at each tenure level, across the two time intervals

The most significant new results with the Klerman classification are those that pertain to the new group of countries with so-called Mixed legal origins. In fact, these 
results are somewhat puzzling. In 1990-1995 these countries are predicted to have the highest notice period scores. By 2000-2005, this shifts dramatically with the largest probability associated with the lowest notice period score ( 49 percent), and sizable movement to lower scores overall. This is counterintuitive to the actual data, perhaps reflecting the small sample size of these countries. All countries of Mixed legal origin have high actual notice period scores over both time periods, with some also showing large improvements ${ }^{9}$

Overall, it seems that between 1990-1995 and 2000-2005, countries maintain or move to higher labour standards only at nine months and four years of service. There is clearly less willingness to maintain the stricter standards at 20 years of service in countries of all legal origins, although there are differences across legal origins.

\section{Predicted Probabilities by Trade Level and Legal Origin}

One of the objectives of this paper was to examine how the impact of legal origins on the stringency of labour standards is affected by the degree of openness of an economy. In the previous discussion, we studied the impact of legal origins, holding the degree of openness constant. In this exercise, we examine the impact of legal origin by allowing openness (as measured by trade share) to vary, holding all other variables constant at their sample means. More specifically, predicted probabilities are calculated for a low, medium, and high level of trade share for each legal origin. Here, low is measured as the tenth percentile, medium as the median, and high as the 95th. A graphical representation of these predicted probabilities are used to best present results for each notice period length. In an effort to condense results, I focus on 2000-2005 only. Figures 4.1 through 4.3 present results for each for each of the three employment tenures using the La Porta classification while Figures 4.4 through

\footnotetext{
${ }^{9}$ Jordan, for example, introduced a change to their labour laws in 1996, moving from no provisions for notice periods to very high ones (one month for notice periods after nine months of service). These higher notice periods are associated with the highest stringency score.
} 
4.6 use the Klerman classification.

Looking first at the probabilities at nine months of employee service (Tables 4.1 and 4.4), there appear to be large variations in the probabilities by legal origin, regardless of the classification scheme used. As noted in the previous section, much of the differences appear to arise from differences between French Civil Law and Common law origins, on the one hand, and other legal origins on the other. Most of these differences are at the low end of notice period scores ( $L=0$ or 1$)$, and the high end $(L=3)$. If we then factor in the effect of openness, we find that the shift from low openness to medium, and then to high openness clearly moderates those differences. For both the La Porta et al. and Klerman classifications, a majority of countries of all legal origins appear to move towards stricter labour standards, particularly towards $\mathrm{L}=2$. The probabilities of being at this level are in the 45-55 percent range across all legal origins, at the highest level of openness. This happens mainly as a result of some tightening of labour standards at the bottom end of notice period scores $(\mathrm{L}=0$, 1) and some at the top end $(L=3)$.

At the next length of employee service, four years, Figures 4.2 and 4.5 show that the variable impacts of legal origins, are in general more muted than observed at nine months of service. This is especially the case with the Klerman classification, while much of the differences in probabilities with the La Porta classification are due to differences between countries of Scandinavian/German legal origins and others. Again, we find that, as we move up the openness scale, the probabilities for all legal origins tend to gravitate towards an average of roughly 50 percent and 35 percent at $\mathrm{L}=1$ and $\mathrm{L}=2$ respectively. This also reflects a move to greater average stringency in labour standards. Overall, with the exception of German/Scandinavian legal origins (under the La Porta classification), legal origin becomes less important as openness increases.

Regardless of the classification of legal origins, findings are most clear-cut for 
workers with 20 years of service. To begin with, as Figures 4.3 and 4.6 indicate, most countries from all legal origins are typically concentrated at a score of $L=1$, with probabilities in approximately the 60-85 percent range at the lowest level of trade share (openness); those with French Civil Law and Common Law origins are also relatively much more likely than other origins to be at the lowest labour standards score $(L=0)$. As openness increases to medium and then to even higher levels, the differences in probabilities by legal origin very clearly moderate, mostly at $L=1$. Specifically, the probabilities at $\mathrm{L}=1$ across all legal origins are in the $70-80$ percent range using the La Porta classification, and at or just above 80 percent using the Klerman classification. This trend is largely the result of countries of French Civil Law and Common Law origins shifting up from the lowest level of stringency $(L=0)$.

\subsection{Extension}

In this section, we extend the analysis of the previous section by predicting the probabilities (by legal origin) that countries would score $\mathrm{L}=1$ or $\mathrm{L}=2$ (or both) on the stringency scale for notice periods, when trade openness is allowed to vary continuously from zero percent to 120 percent. ${ }^{10}$ We have seen that legal origin does matter at low levels of openness but less at high levels of openness. Allowing trade to vary continuously would shed more light on the differences by legal origin and how these behave at different levels of trade openness.

In the previous section we saw that there is a movement towards a score of $L=2$ with a relatively high probability as openness increases, at nine months of employee service. A similar movement is observed at $\mathrm{L}=1$ and $\mathrm{L}=2$ at four years of service, and at $\mathrm{L}=1$ at 20 years of service. These trends are further studied in Figures 4.7, 4.8 and 4.9 respectively.

\footnotetext{
${ }^{10}$ Predicted probabilities are calculated at each integer value of trade share, holding all else at mean values (except for legal origin dummies).
} 
Starting with the shortest tenure of service (nine months), Figure 4.7 shows that both legal origin classifications show the same overall trend. Countries of French Civil Law, Common Law, Socialist Code, or Mixed legal origin are less likely to be at $\mathrm{L}=2$ when openness is low. As trade openness increases, the predicted probabilities for these countries rise almost monotonically, with a small tendency to flatten or fall slightly at very high levels of trade openness. For countries with Scandinavian/German legal origins, the probabilities are relatively flat or rise slightly, suggesting relatively stable labour standards (at $\mathrm{L}=2$ ), regardless of the level of trade. It is quite clear that the pattern of movement (that is, narrowing of differences) suggests that legal origins are less important at high levels of openness.

Figure 4.8 repeats the exercise for employees with four years of service, for notice period scores of $\mathrm{L}=1$ and $\mathrm{L}=2$. As with the previous results, legal origins do matter at low levels of trade openness. However, with the Klerman classification, the differences across legal origin are relatively small compared to those associated with the La Porta classification. As openness rises, in all but one case, there is a narrowing of probabilities, which tend approximately to the $50-60$ percent range for $L=1$ and the 30-45 range for $\mathrm{L}=2$. The major difference is for countries with Scandinavian/German origins. First, for the La Porta classification, this group of countries is the only one for which probabilities respond in a non-monotonic fashion to trade openness, as is abundantly clear from Figure 4.8. Second, for $\mathrm{L}=1$, it is clear that the probability diverges significantly from those to which the other groups of countries tend to. But for $L=2$, despite the monotonic relationship, the probabilities do tend to those of other countries at high levels of openness. In general, greater openness is seen to facilitate a shift towards similar notice period labour standards for most countries.

Finally, Figure 4.9 depicts predicted probabilities of $\mathrm{L}=1$ by trade share for workers with 20 years of service. It shows, with more detail, the response to openness observed in Figures 4.3 and 4.6. The importance of legal origins is seen to fall with 
increasing openness. Countries of Scandinavian/German legal origins show a general constancy in predicted probabilities (in the high 80-85 percent range) along the trade openness scale, with both the La Porta and Klerman classifications. This pattern is also displayed by countries of Mixed legal origins (Klerman classification). For both legal origin classifications, countries of French Civil and Common Law legal traditions show low probabilities at low levels of openness, but these increase as openness increases. All of these movements are mostly monotonic. Countries of Socialist code origin also show a similar trend, though with some evidence of a decline in probability with trade shares above approximately 65 percent.

These results again reinforce the finding of the previous section that as trade becomes more important and, by implication, international competitive pressures increase, there is a move towards common labour standards by a majority of countries. In this regard, although, as the tenure of workers increases, the move is to weaker standards, there is clearly no race-to-the-bottom with greater openness. This could be because greater openness also results in domestic pressures by labour groups for stricter labour standards, or reflects labour provisions in trade agreements, for example.

\subsection{Conclusions}

The goal of this paper has been to examine the impact of trade on labour standards in the context of legal origins. Attention has also been given to how trade and legal origins interact in impacting on those standards. Two alternate approaches were used to measure labour standards, both based on advance notice periods employers are required to give employees upon dismissal. Each of these were examined at three levels of employee tenure of service (nine months, four years, and 20 years) for 72 
countries for which data are available over two time periods, 1990-1995 and 20002005. The choice of looking at cross-sections averaged over two time intervals was predicated on the fact that notice periods change only slowly over time. The effects of legal origins were studied using two alternative classifications; the first, based on Porta et al. (1999) and the second, due to Klerman et al (2011), which allows for the role of colonial origins in shaping legal traditions.

Given the two alternative indicators of labour standards, two different econometric models were used - a Tobit model on raw notice periods (measured in months) and a a four-choice ordered probit model on an ordinal ranking of the stringency of notice periods. Both models are estimated using controls for variables reflecting income differences, as well as differences in legal origins, trade shares (to measure openness), as well as interaction terms to capture the interaction between trade openness and legal origins.

Overall, results from the Tobit regressions suggest that, where legal origins matter, mostly in the regressions based on the Klerman classification, they tend to imply longer notice periods for countries with Scandinavian/German, Mixed or Common Law legal origins relative to countries with French Civil Law origins. However, this impact is not independent of openness; generally, longer notice periods would typically occur at low levels of openness, whereas at high levels of openness, the impact of legal origins could lower notice periods, relative to the default case (French Civil Law). That is, labour protection becomes less important when the degree of openness is high. At the same time, the impact of increased trade openness by itself is to increase notice periods in countries with French Civil Law legal origins, although that impact is lower (and even negative) for countries of other legal origins.

Using ordered probit analysis on the four-level ranking of notice periods, simulated probabilities of the stringency of labour standards by trade openness and legal origin tends to reinforce the findings of the Tobit results, and also leads to some additional 
implications. In particular, legal origins seem to matter most for economies that are least open, with these economies showing significant variation in the stringency of notice period regulation. Thus, by affecting the regulatory framework and its flexibility, legal origins are most important when the pressures of international competitiveness are minimal. As trade openness increases and economies become much more globalized, these pressures become important and differences due to legal origin appear to wane in relative importance. In other words, although greater openness also likely increases domestic pressures to strengthen labour protection, these are, perhaps, not enough to counter the international competitive pressures that also arise from greater openness. Furthermore, at high levels of openness, countries show a tendency to move to a similar level of stringency of labour standards pertaining to notice periods. At the longest tenure of employee service (20 years), there is a tendency to gravitate towards a low level of stringency $(L=1)$, while at the shortest level of employee service (9 months), this shift is towards a stricter level $(L=2)$. In the intermediate case (4 years), the movement is towards the middle $(L=1,2)$.

These results could be interpreted as implying that, regardless of legal origins, in an environment of significant openness, countries are likely to provide the lowest level of protection to long-term employees and the highest to short-term employees. In any event, there is little tendency to gravitate towards the highest level of stringency $(L=3)$ - a "race-to-the-top" - or towards the lowest $(L=0)$ - a race-tothe-bottom. The added implication is that there is no race-to-the-bottom for countries that trade a great deal, since the tendency is to move either towards a greater level of stringency $(L=2)$ or, at worst, no lower than the second level $(L=1)$. Yet, it would appear that very open countries work towards eliminating differences in labour standards. This type of behaviour in a globalized environment is reminiscent of Harold Hotelling's overall observation in his famous 1929 paper, "The Stability of Competition", that competition leads to "sameness" and deviations from this are 
disadvantageous (Hotelling, 1929). ${ }^{11}$ There are elements of a pseudo-RTB argument embedded here, namely that if labour standards are set too high by one country, it is advantageous for others to set a slightly lower standard to gain a competitive edge, which in turn leads to a further reduction of standards by the first country, and so on. However, countries would not move to the bottom because of domestic pressures by labour groups, as well as the fear of international sanctions, the loss of consumer goodwill, or the inclusion of labour provisions in trade agreements, for example.

Finally, extensions of the research conducted in this chapter are possible . First, the fRDB database exploited in this paper also contains information on severance pay and unemployment benefits. An interesting analysis would be to see if the results in this paper also apply to these aspects of employment protection. Furthermore, to more thoroughly assess the impact of trade, the analysis could be expanded to include different measures for trade integration and trade policy. Due to space constraints, this was not possible in the current paper. Estimating the model from panel data would appear to be a natural extension. Apart from increasing the size of the sample, this would also allow the use more powerful econometric techniques that exploit such data to deal with problems such as unobserved heterogeneity, which purely crosssectional studies suffer from. The main difficulty would be that labour protection measures often change only slowly so that annual variation in that data would be limited.

\section{References}

Acemoglu, D. and S. Johnson (2005), "Unbundling institutions." Journal of Political Economy, 113, 949-995.

\footnotetext{
${ }^{11} \mathrm{He}$ pointed to standardization of products as an example, or to the tendency of politicians to offer very similar platforms in the lead up to elections.
} 
Acemoglu, D., S. Johnson, and J. Robinson (2001), "Colonial origins of comparative development: An empirical investigation." American Economic Review, 91, 13691401.

Aleksynska, M. and M. Schindler (2011), "Labor market regulation in low-, middle-, and high-income countries: a new panel database." IMF Working Paper.

Bonnal, M. (2010), "Export performance, labor standards and institutions: Evidence from a dynamic panel data model." Journal of Labor Research, 31, 53-66.

Botero, J., S. Djankov, R. La Porta, F. Lopez-de-Silanes, and A. Shleifer (2004), "The regulation of labor." The Quarterly Journal of Economics, 119, 1339-1382.

Busse, M. (2002), "Do labor standards affect comparative advantage in developing countries?" World Development, 31, 1921-1932.

Busse, M. (2004), "On the determinants of core labour standards: The case of developing countries." Economics Letters, 83, 211-217.

Dehejia, V. and Y. Samy (2008), "Labor standards and economic integration in the european union: An empirical analysis." Journal of Economic Integration, 23, 817847.

Dehejia, V. and Y. Samy (2011), "Labour standards and economic integration in the European Union: A gravity model approach." International Trade Journal, 25, $581-618$.

Edmonds, E. and N. Pavcnik (2006), "International trade and child labor: Crosscountry evidence." Journal of International Economics, 68, 115-140.

Flanagan, R. (2006), Globalization and Labor Conditions. Oxford University Press.

Hotelling, H. (1929), "Stability in competition." The Economic Journal, 39, 41-57. 
International Labour Organization (2009), The world of work report: The Global jobs crisis and beyond.

Jansen, M., C. Häberli, and José-Antonio Monteiro (2012), "Regional trade agreements and domestic labour regulation." In Policy Priorities for International Trade and Jobs (D. Lippoldt, ed.), OECD, Paris.

Klerman, D., P. Mahoney, H. Spamann, and M. Weinstein (2011), "Legal origin or colonial history?" Journal of Legal Analysis, 3, 379-409.

Kucera, D. and R. Sarna (2006), "Trade union rights, democracy, and exports: A gravity model approach." Review of International Economics, 14, 859-882.

La Porta, R., F. Lopez-de-Silanes, and A. Shleifer (2008), "The economic consequences of legal origins." Journal of Economic Literature, 46, 285-332.

La Porta, R., F. Lopez-de-Silanes, A. Shleifer, and R. Vishny (1997), "Legal determinants of external finance." Journal of Finance, 52, 1131-1150.

La Porta, R., F. Lopez-de-Silanes, A. Shleifer, and R. Vishny (1998), "Law and finance." Journal of Political Economy, 106, 1113-1155.

La Porta, R., F. Lopez-de-Silanes, A. Shleifer, and R. Vishny (1999), "The quality of government." Journal of Law, Economics, and Organization, 15, 222-279.

Mah, J. (1997), "Core labour standards and export performance in developing countries." The World Economy, 2, 773-785.

Neumayer, E. and I. De Soysa (2006), "Globalization and the right to free association and collective bargaining: An empirical analysis." World Development, 34, 31-49.

OECD (2004), "Employment protection regulation and labour market performance." In OECD Employment Outlook, Paris. 
Teorell, J., M. Samanni, S. Holmberg, and B. Rothstein (2011), The Quality of Government Dataset (v. April 6, 2011). The University of Gothenburg: The Quality of Government Institute, http://www.qog.pol.gu.se.

The World Bank (2012), World Development Indicators. Washington, DC.

Van Beers, C. (1998), "Labour standards and trade flows of OECD countries." The World Economy, 21, 57-73. 


\subsection{Appendix}

Table 4.1: Sample of Countries

\begin{tabular}{cccc}
\hline \hline Albania & Denmark & Jordan & Russia \\
Algeria & Dominican Rep. & Kenya & Senegal \\
Argentina & Egypt & Korea & South Africa \\
Australia & El Salvador & Madagascar & Spain \\
Austria & Ethiopia & Malaysia & Sri Lanka \\
Bangladesh & Finland & Mexico & Sweden \\
Belgium & France & Morocco & Switzerland \\
Bolivia & Georgia & Mozambique & Thailand \\
Brazil & Germany & Nepal & Tunisia \\
Bulgaria & Ghana & Netherlands & Turkey \\
Burkina Faso & Greece & New Zealand & Uganda \\
Cameroon & Guatemala & Nicaragua & Ukraine \\
Canada & Hungary & Norway & United Kingdom \\
Chile & India & Pakistan & United States \\
China & Indonesia & Paraguay & Uruguay \\
Colombia & Italy & Peru & Venezuela \\
Costa Rica & Jamaica & Philippines & Vietnam \\
Cote d'Ivoire & Japan & Portugal & Zimbabwe \\
\hline \hline
\end{tabular}


Table 4.2: Countries by Legal Origin

\begin{tabular}{|c|c|c|c|c|c|c|c|c|c|}
\hline \multicolumn{5}{|c|}{ La Porta Classification } & \multicolumn{5}{|c|}{ Klerman Classification } \\
\hline Common Law & \multicolumn{2}{|c|}{ French Civil Law } & \multirow{2}{*}{$\begin{array}{l}\text { Socialist Code } \\
\text { Albania }\end{array}$} & \multirow{2}{*}{$\begin{array}{l}\text { Scandinavian/ } \\
\text { German } \\
\text { Austria }\end{array}$} & \multirow{2}{*}{$\begin{array}{l}\text { Common Law } \\
\text { Australia }\end{array}$} & \multicolumn{2}{|c|}{ French Civil Law } & \multirow{2}{*}{$\begin{array}{l}\text { Mixed } \\
\text { Jordan }\end{array}$} & \multirow{2}{*}{$\begin{array}{l}\text { Scandinavian/ } \\
\text { German } \\
\text { Austria }\end{array}$} \\
\hline Australia & Algeria & Jordan & & & & Albania & Italy & & \\
\hline Bangladesh & Argentina & Madagascar & Bulgaria & Denmark & Bangladesh & Algeria & Madagascar & Philippines & Bulgaria \\
\hline Canada & Belgium & Mexico & China & Finland & Canada & Argentina & Mexico & South Africa & China \\
\hline Ghana & Bolivia & Morocco & Georgia & Germany & Ghana & Belgium & Morocco & Sri Lanka & Denmark \\
\hline India & Brazil & Mozambique & Hungary & Japan & India & Bolivia & Mozambique & Thailand & Finland \\
\hline Jamaica & Burkina Faso & Netherlands & Russia & Korea & Jamaica & Brazil & Netherlands & Zimbabwe & Georgia \\
\hline Kenya & Cameroon & Nicaragua & Ukraine & Norway & Kenya & Burkina Faso & Nicaragua & & Germany \\
\hline Malaysia & Chile & Paraguay & Vietnam & Sweden & Malaysia & Cameroon & Paraguay & & Hungary \\
\hline Nepal & Colombia & Peru & & Switzerland & Nepal & Chile & Peru & & Japan \\
\hline New Zealand & Costa Rica & Philippines & & & New Zealand & Colombia & Portugal & & Korea \\
\hline Pakistan & Cote d'Ivoire & Portugal & & & Pakistan & Costa Rica & Russia & & Norway \\
\hline South Africa & Dominican Rep. & Senegal & & & Uganda & Cote d'Ivoire & Senegal & & Sweden \\
\hline Sri Lanka & Egypt & Spain & & & United Kingdom & Dominican Rep. & Spain & & Switzerland \\
\hline Thailand & El Salvador & Tunisia & & & United States & Egypt & Tunisia & & \\
\hline Uganda & Ethiopia & Turkey & & & & El Salvador & Turkey & & \\
\hline United Kingdom & France & Uruguay & & & & Ethiopia & Ukraine & & \\
\hline United States & Greece & Venezuela & & & & France & Uruguay & $\cdot$ & \\
\hline \multirow[t]{3}{*}{ Zimbabwe } & Guatemala & & & & & Greece & Venezuela & & \\
\hline & Indonesia & & & & & Guatemala & Vietnam & & \\
\hline & Italy & & & & & Indonesia & & & \\
\hline
\end{tabular}


Table 4.3: Summary Statistics on Notice Periods

\begin{tabular}{l|cccc|cccc}
\hline \hline & \multicolumn{4}{|c}{$1990-1995$} & \multicolumn{5}{c}{$2000-2005$} \\
\hline Variable & Mean & Std. Dev. & Min & Max & Mean & Std. Dev. & Min & Max \\
\hline Length of Tenure: & & & & & & & & \\
nine months & 0.82 & 0.66 & 0.00 & 3.00 & 0.91 & 0.67 & 0.00 & 3.00 \\
four years & 1.13 & 0.83 & 0.00 & 3.60 & 1.23 & 0.77 & 0.00 & 3.00 \\
20 years & 1.86 & 1.88 & 0.00 & 9.37 & 2.00 & 1.84 & 0.00 & 9.37 \\
Score, nine months & 1.48 & 0.91 & 0.00 & 3.00 & 1.61 & 0.88 & 0.00 & 3.00 \\
Score, four years & 1.22 & 0.78 & 0.00 & 3.00 & 1.31 & 0.74 & 0.00 & 3.00 \\
Score, 20 years & 1.94 & 0.28 & 1.00 & 3.00 & 1.90 & 0.35 & 1.00 & 3.00 \\
\hline Trade: & & & & & & & & \\
Openness (\%) & 56.76 & 27.37 & 15.56 & 158.95 & 70.72 & 33.40 & 22.79 & 206.63 \\
\hline Control Variables: & & & & & & & & \\
(log) real GDP/capita & 7.77 & 1.60 & 4.73 & 10.47 & 7.97 & 1.61 & 4.89 & 10.57 \\
Agriculture Share (\% GDP) & 16.39 & 13.76 & 1.33 & 62.11 & 12.09 & 10.37 & 0.91 & 45.64 \\
\hline \hline
\end{tabular}

Note: All variables represent five year averages for 72 countries. Raw notice periods are measured in terms of months while the Score of notice periods is based on a 0 to 3 scale. Real GDP per capita is measured in constant 2005 dollars. See main paper for data sources and construction. 
Table 4.4: Notice Periods by Legal Origin

\begin{tabular}{l|ccc|ccc}
\hline \hline & \multicolumn{3}{|c|}{ Raw Notice Periods } & \multicolumn{3}{c}{ Notice Period Score } \\
Legal Origin & nine months & four years & 20 years & nine months & four years & 20 years \\
\hline La Porta Classification & & & & & & \\
Common Law & 0.68 & 1.09 & 1.56 & 1.33 & 1.17 & 1.94 \\
& $(0.52)$ & $(0.68)$ & $(0.97)$ & $(0.77)$ & $(0.62)$ & $(0.24)$ \\
French Civil Law & 0.88 & 1.13 & 1.81 & 1.50 & 1.24 & 1.93 \\
& $(0.77)$ & $(0.81)$ & $(2.02)$ & $(0.96)$ & $(0.80)$ & $(0.34)$ \\
Socialist & 1.41 & 1.56 & 1.91 & 2.31 & 1.63 & 1.63 \\
& $(0.53)$ & $(0.52)$ & $(0.82)$ & $(0.59)$ & $(0.52)$ & $(0.52)$ \\
German/Scandinavian & 1.05 & 1.60 & 3.72 & 2.02 & 1.57 & 1.89 \\
& $(0.34)$ & $(0.85)$ & $(2.22)$ & $(0.46)$ & $(0.87)$ & $(0.33)$ \\
\hline Klerman & & & & & & \\
Common Law & 0.63 & 0.90 & 1.50 & 1.29 & 1.00 & 2.00 \\
& $(0.41)$ & $(0.48)$ & $(1.00)$ & $(0.61)$ & $(0.39)$ & $(0.00)$ \\
French Civil Law & 0.95 & 1.21 & 1.88 & 1.58 & 1.33 & 1.88 \\
& $(0.79)$ & $(0.82)$ & $(1.97)$ & $(0.99)$ & $(0.81)$ & $(0.39)$ \\
Mixed & 0.92 & 1.50 & 1.50 & 1.67 & 1.50 & 1.83 \\
& $(0.66)$ & $(0.84)$ & $(0.84)$ & $(1.03)$ & $(0.84)$ & $(0.41)$ \\
German/Scandinavian & 1.09 & 1.49 & 3.10 & 2.05 & 1.47 & 1.85 \\
& $(0.40)$ & $(0.77)$ & $(2.12)$ & $(0.49)$ & $(0.77)$ & $(0.38)$ \\
\hline \hline
\end{tabular}

Note: Standard deviations are in parentheses. Notice periods (raw measures and scores) are for 2000-2005. 
Table 4.5: Tobit Regressions I-A

\begin{tabular}{|c|c|c|c|c|c|c|}
\hline & \multicolumn{3}{|c|}{ 1990-1995 } & \multicolumn{3}{|c|}{$2000-2005$} \\
\hline & nine months & four years & 20 years & nine months & four years & 20 years \\
\hline \multicolumn{7}{|l|}{ Variables } \\
\hline \multirow[t]{2}{*}{ (log) real GDP per capita } & -1.181 & -1.539 & $-3.253^{*}$ & -1.521 & -1.918 & -2.466 \\
\hline & $(0.246)$ & $(0.169)$ & $(0.064)$ & $(0.202)$ & $(0.173)$ & $(0.300)$ \\
\hline \multirow[t]{2}{*}{ (log) real GDP per capita squared } & 0.062 & 0.089 & $0.229^{* *}$ & 0.082 & 0.108 & 0.180 \\
\hline & $(0.304)$ & $(0.177)$ & $(0.031)$ & $(0.220)$ & $(0.169)$ & $(0.191)$ \\
\hline \multirow[t]{2}{*}{ Agriculture share of GDP } & -0.017 & -0.021 & 0.005 & -0.019 & -0.026 & 0.025 \\
\hline & $(0.225)$ & $(0.277)$ & $(0.893)$ & $(0.401)$ & $(0.389)$ & $(0.618)$ \\
\hline \multirow[t]{2}{*}{ Common Law Legal Origin } & -0.010 & -0.281 & 0.391 & -0.146 & -0.472 & 0.258 \\
\hline & $(0.984)$ & $(0.637)$ & $(0.723)$ & $(0.699)$ & $(0.247)$ & $(0.790)$ \\
\hline \multirow[t]{2}{*}{ Socialist Legal Origin } & 0.353 & -0.007 & 1.321 & $1.283^{* *}$ & $1.249^{*}$ & $2.196^{*}$ \\
\hline & $(0.529)$ & $(0.990)$ & $(0.248)$ & $(0.031)$ & $(0.089)$ & $(0.094)$ \\
\hline \multirow[t]{2}{*}{ Scandinavian/German Legal Origin } & 0.989 & -0.460 & 1.060 & 0.507 & -0.835 & 0.063 \\
\hline & $(0.127)$ & $(0.538)$ & $(0.732)$ & $(0.190)$ & $(0.170)$ & $(0.981)$ \\
\hline \multirow[t]{2}{*}{ Trade Share $(t-1)$} & 0.008 & 0.002 & $0.039^{* *}$ & $0.007^{*}$ & 0.002 & $0.026^{*}$ \\
\hline & $(0.241)$ & $(0.723)$ & $(0.038)$ & $(0.059)$ & $(0.567)$ & $(0.077)$ \\
\hline \multirow[t]{2}{*}{ Trade Share $(t-1) \times$ Common Law } & -0.003 & 0.004 & -0.016 & -0.003 & 0.005 & -0.012 \\
\hline & $(0.717)$ & $(0.702)$ & $(0.454)$ & $(0.527)$ & $(0.275)$ & $(0.436)$ \\
\hline \multirow[t]{2}{*}{ Trade Share $(t-1) \times$ Socialist } & -0.005 & -0.001 & -0.033 & -0.011 & -0.010 & -0.027 \\
\hline & $(0.660)$ & $(0.933)$ & $(0.194)$ & $(0.113)$ & $(0.206)$ & $(0.168)$ \\
\hline \multirow[t]{2}{*}{ Trade Share $(t-1) \times$ Scandinavian/German } & -0.008 & 0.017 & -0.013 & -0.004 & $0.019^{* *}$ & 0.009 \\
\hline & $(0.379)$ & $(0.167)$ & $(0.788)$ & $(0.424)$ & $(0.049)$ & $(0.793)$ \\
\hline \multirow[t]{2}{*}{ Constant } & 5.892 & 7.615 & 10.620 & 7.347 & 9.483 & 7.734 \\
\hline & $(0.184)$ & $(0.124)$ & $(0.155)$ & $(0.180)$ & $(0.146)$ & $(0.460)$ \\
\hline Observations & 72 & 72 & 72 & 72 & 72 & 72 \\
\hline Log likelihood & -77.289 & -90.809 & -129.623 & -73.061 & -82.815 & -132.107 \\
\hline Pseudo- $\mathbf{R}^{2}$ & 0.058 & 0.047 & 0.100 & 0.097 & 0.070 & 0.082 \\
\hline F-statistic & 1.979 & 1.045 & 3.824 & 2.785 & 1.810 & 2.590 \\
\hline
\end{tabular}

$p$-values in parentheses

" $p<0.10, * * p<0.05, \cdots * p<0.01$

Note that legal origin dummies are based on the La Porta classification.

The dependent variables are advanced notice periods after nine months, four years, and 20 years of service respectively. 
Table 4.6: Tobit Regressions II-A

\begin{tabular}{|c|c|c|c|c|c|c|}
\hline & \multicolumn{3}{|c|}{$1990-1995$} & \multicolumn{3}{|c|}{$2000-2005$} \\
\hline & nine months & four years & 20 years & nine months & four years & 20 years \\
\hline \multicolumn{7}{|l|}{ Variables } \\
\hline \multirow{2}{*}{ (log) real GDP per capita } & -1.097 & -1.664 & $-3.290^{*}$ & -1.070 & -1.323 & -2.098 \\
\hline & $(0.260)$ & $(0.134)$ & $(0.052)$ & $(0.349)$ & $(0.344)$ & $(0.381)$ \\
\hline \multirow[t]{2}{*}{ (log) real GDP per capita squared } & 0.057 & 0.100 & $0.232^{* *}$ & 0.053 & 0.077 & 0.160 \\
\hline & $(0.307)$ & $(0.123)$ & $(0.018)$ & $(0.386)$ & $(0.310)$ & $(0.223)$ \\
\hline \multirow[t]{2}{*}{ Agriculture share of GDP } & -0.017 & -0.019 & 0.002 & -0.019 & -0.007 & 0.029 \\
\hline & $(0.266)$ & $(0.300)$ & $(0.948)$ & $(0.493)$ & $(0.846)$ & $(0.622)$ \\
\hline \multirow[t]{2}{*}{ Common Law Legal Origin } & 0.468 & 0.278 & $1.650^{* *}$ & 0.247 & -0.130 & 1.142 \\
\hline & $(0.267)$ & $(0.580)$ & $(0.048)$ & $(0.483)$ & $(0.751)$ & $(0.229)$ \\
\hline \multirow[t]{2}{*}{ Mixed Legal Origin } & $2.718^{* *}$ & $4.455^{* *}$ & $7.633^{\star \star *}$ & -0.642 & 0.785 & $2.075^{*}$ \\
\hline & $(0.003)$ & $(0.011)$ & $(0.000)$ & $(0.369)$ & $(0.367)$ & $(0.082)$ \\
\hline \multirow[t]{2}{*}{ Scandinavian/German Legal Origin } & $1.399^{* *}$ & 0.505 & 2.761 & $0.985^{\cdots *}$ & 0.491 & $1.699^{*}$ \\
\hline & $(0.017)$ & $(0.468)$ & $(0.209)$ & $(0.000)$ & $(0.134)$ & $(0.089)$ \\
\hline \multirow[t]{2}{*}{ Trade Share $(t-1)$} & $0.015^{* * *}$ & $0.010^{*}$ & $0.055^{* * *}$ & $0.009^{\cdots \cdots}$ & $0.006^{*}$ & $0.033^{* *}$ \\
\hline & $(0.004)$ & $(0.051)$ & $(0.000)$ & $(0.007)$ & $(0.074)$ & $(0.016)$ \\
\hline \multirow[t]{2}{*}{ Trade Share $(t-1) \times$ Common Law } & $-0.012^{*}$ & -0.008 & $-0.040^{* * *}$ & $-0.008^{* *}$ & -0.003 & $-0.026^{*}$ \\
\hline & $(0.071)$ & $(0.315)$ & $(0.007)$ & $(0.046)$ & $(0.540)$ & $(0.067)$ \\
\hline \multirow[t]{2}{*}{ Trade Share $(t-1) \times$ Mixed } & $-0.054^{* * *}$ & $-0.076^{* * *}$ & $-0.143^{\cdots *}$ & 0.003 & -0.006 & $-0.030^{*}$ \\
\hline & $(0.005)$ & $(0.007)$ & $(0.000)$ & $(0.651)$ & $(0.490)$ & $(0.056)$ \\
\hline \multirow[t]{2}{*}{ Trade Share $(t-1) \times$ Scandinavian/German } & $-0.020^{* *}$ & -0.006 & -0.051 & $-0.010^{* * *}$ & -0.003 & -0.019 \\
\hline & $(0.024)$ & $(0.566)$ & $(0.123)$ & $(0.001)$ & $(0.588)$ & $(0.175)$ \\
\hline \multirow[t]{2}{*}{ Constant } & 5.229 & 7.502 & 10.021 & 5.512 & 6.319 & 5.642 \\
\hline & $(0.229)$ & $(0.129)$ & $(0.185)$ & $(0.313)$ & $(0.340)$ & $(0.613)$ \\
\hline Observations & 72 & 72 & 72 & 72 & 72 & 72 \\
\hline Log likelihood & -73.631 & -87.863 & -124.293 & -73.551 & -84.462 & -130.980 \\
\hline Pseudo-R ${ }^{2}$ & 0.102 & 0.078 & 0.137 & 0.091 & 0.051 & 0.090 \\
\hline F-statistic & 2.907 & 2.005 & 6.653 & 5.397 & 1.646 & 2.387 \\
\hline
\end{tabular}

$p$-values in parentheses

- $p<0.10, " p<0.05, \cdots p<0.01$

Note that legal origin dummies are based on the Klerman classification.

The dependent variables are advanced notice periods after nine months, four years, and 20 years of service respectively. 
Table 4.7: Tobit Regressions I-B, Marginal Effects

\begin{tabular}{|c|c|c|c|c|c|c|}
\hline & \multicolumn{3}{|c|}{ 1990-1995 } & \multicolumn{3}{|c|}{$2000-2005$} \\
\hline & nine months & four years & 20 years & nine months & four years & 20 years \\
\hline \multicolumn{7}{|l|}{ Variables } \\
\hline \multirow[t]{2}{*}{ (log) real GDP per capita } & -1.008 & -1.539 & $-2.765^{*}$ & -1.376 & -1.806 & -2.158 \\
\hline & $(0.242)$ & $(0.169)$ & $(0.064)$ & $(0.205)$ & $(0.176)$ & $(0.303)$ \\
\hline \multirow[t]{2}{*}{ (log) real GDP per capita squared } & 0.053 & 0.089 & $0.195^{\circ *}$ & 0.074 & 0.101 & 0.157 \\
\hline & $(0.300)$ & $(0.177)$ & $(0.031)$ & $(0.223)$ & $(0.172)$ & $(0.193)$ \\
\hline \multirow[t]{2}{*}{ Agriculture share of GDP } & -0.015 & -0.021 & 0.004 & -0.017 & -0.024 & 0.022 \\
\hline & $(0.226)$ & $(0.277)$ & $(0.893)$ & $(0.403)$ & $(0.391)$ & $(0.615)$ \\
\hline \multirow[t]{2}{*}{ Common Law Legal Origin ${ }^{a}$} & -0.009 & -0.281 & 0.338 & -0.131 & -0.433 & 0.228 \\
\hline & $(0.984)$ & $(0.637)$ & $(0.728)$ & $(0.696)$ & $(0.237)$ & $(0.792)$ \\
\hline \multirow[t]{2}{*}{ Socialist Legal Origin ${ }^{a}$} & 0.315 & -0.007 & 1.196 & $1.237^{* *}$ & $1.220^{*}$ & 2.065 \\
\hline & $(0.542)$ & $(0.990)$ & $(0.267)$ & $(0.034)$ & $(0.092)$ & $(0.104)$ \\
\hline \multirow[t]{2}{*}{ Scandinavian/German Legal Origin ${ }^{a}$} & 0.917 & -0.460 & 0.949 & 0.476 & -0.722 & 0.056 \\
\hline & $(0.145)$ & $(0.538)$ & $(0.743)$ & $(0.198)$ & $(0.127)$ & $(0.981)$ \\
\hline \multirow[t]{2}{*}{ Trade Share $(t-1)$} & 0.007 & 0.002 & $0.033^{* *}$ & $0.006^{*}$ & 0.002 & $0.023^{*}$ \\
\hline & $(0.246)$ & $(0.723)$ & $(0.042)$ & $(0.057)$ & $(0.566)$ & $(0.074)$ \\
\hline \multirow[t]{2}{*}{ Trade Share $(t-1) \times$ Common Law } & -0.003 & 0.004 & -0.013 & -0.002 & 0.005 & -0.010 \\
\hline & $(0.718)$ & $(0.702)$ & $(0.460)$ & $(0.527)$ & $(0.276)$ & $(0.437)$ \\
\hline \multirow[t]{2}{*}{ Trade Share $(t-1) \times$ Socialist } & -0.004 & -0.001 & -0.028 & -0.010 & -0.010 & -0.023 \\
\hline & $(0.660)$ & $(0.933)$ & $(0.194)$ & $(0.113)$ & $(0.207)$ & $(0.167)$ \\
\hline \multirow[t]{2}{*}{ Trade Share $(t-1) \times$ Scandinavian/German } & -0.007 & 0.017 & -0.011 & -0.003 & $0.018^{*}$ & 0.008 \\
\hline & $(0.383)$ & $(0.167)$ & $(0.789)$ & $(0.422)$ & $(0.051)$ & $(0.793)$ \\
\hline Observations & 72 & 72 & 72 & 72 & 72 & 72 \\
\hline \multicolumn{7}{|l|}{$p$-values in parentheses } \\
\hline \multicolumn{7}{|l|}{ a for discrete change of dummy variable from 0 to 1} \\
\hline \multicolumn{7}{|l|}{${ }^{*} p<0.10,{ }^{* *} p<0.05,{ }^{* * *} p<0.01$} \\
\hline Note that legal arigin dummies are based on the La I & to orouifin & & & & & \\
\hline
\end{tabular}


Table 4.8: Tobit Regressions II-B, Marginal Effects

\begin{tabular}{|c|c|c|c|c|c|c|}
\hline & \multicolumn{3}{|c|}{$1990-1995$} & \multicolumn{3}{|c|}{$2000-2005$} \\
\hline & nine months & four years & 20 years & nine months & four years & 20 years \\
\hline \multicolumn{7}{|l|}{ Variables } \\
\hline \multirow[t]{2}{*}{ (log) real GDP per capita } & -0.941 & -1.483 & $-2.832^{*}$ & -0.966 & -1.239 & -1.844 \\
\hline & $(0.255)$ & $(0.134)$ & $(0.053)$ & $(0.350)$ & $(0.346)$ & $(0.385)$ \\
\hline \multirow[t]{2}{*}{ (log) real GDP per capita squared } & 0.049 & 0.089 & $0.200^{* *}$ & 0.048 & 0.072 & 0.141 \\
\hline & $(0.302)$ & $(0.123)$ & $(0.019)$ & $(0.387)$ & $(0.313)$ & $(0.228)$ \\
\hline \multirow[t]{2}{*}{ Agriculture share of GDP } & -0.015 & -0.017 & 0.002 & -0.017 & -0.006 & 0.026 \\
\hline & $(0.263)$ & $(0.301)$ & $(0.948)$ & $(0.493)$ & $(0.847)$ & $(0.620)$ \\
\hline \multirow[t]{2}{*}{ Common Law Legal Origin ${ }^{a}$} & 0.421 & 0.253 & $1.510^{*}$ & 0.227 & -0.120 & 1.046 \\
\hline & $(0.283)$ & $(0.585)$ & $(0.054)$ & $(0.488)$ & $(0.750)$ & $(0.239)$ \\
\hline \multirow[t]{2}{*}{ Mixed Legal Origin ${ }^{a}$} & $2.626^{* * *}$ & $4.352^{* *}$ & $7.401^{* * *}$ & -0.518 & 0.761 & $1.960^{\circ}$ \\
\hline & $(0.003)$ & $(0.011)$ & $(0.000)$ & $(0.289)$ & $(0.374)$ & $(0.090)$ \\
\hline \multirow[t]{2}{*}{ Scandinavian/German Legal Origin ${ }^{a}$} & $1.302^{* *}$ & 0.464 & 2.564 & $0.932^{* * *}$ & 0.469 & $1.568^{*}$ \\
\hline & $(0.019)$ & $(0.475)$ & $(0.224)$ & $(0.000)$ & $(0.135)$ & $(0.098)$ \\
\hline \multirow[t]{2}{*}{ Trade Share $(t-1)$} & $0.013^{* * *}$ & $0.009^{* *}$ & $0.048^{* * *}$ & $0.008^{* * *}$ & $0.006^{*}$ & $0.029^{* *}$ \\
\hline & $(0.003)$ & $(0.046)$ & $(0.000)$ & $(0.006)$ & $(0.070)$ & $(0.015)$ \\
\hline \multirow[t]{2}{*}{ Trade Share $(t-1) \times$ Common Law } & $-0.010^{*}$ & -0.007 & $-0.035^{* *}$ & $-0.007^{* *}$ & -0.003 & $-0.023^{*}$ \\
\hline & $(0.072)$ & $(0.312)$ & $(0.006)$ & $(0.045)$ & $(0.538)$ & $(0.064)$ \\
\hline \multirow[t]{2}{*}{ Trade Share $(t-1) \times$ Mixed } & $-0.046^{* * *}$ & $-0.068^{* * * *}$ & $-0.123^{* * *}$ & 0.003 & -0.006 & $-0.027^{*}$ \\
\hline & $(0.004)$ & $(0.007)$ & $(0.000)$ & $(0.651)$ & $(0.489)$ & $(0.054)$ \\
\hline \multirow[t]{2}{*}{ Trade Share $(t-1) \times$ Scandinavian/German } & $-0.017^{* *}$ & -0.005 & -0.044 & $-0.009^{* * *}$ & -0.002 & -0.017 \\
\hline & $(0.023)$ & $(0.563)$ & $(0.124)$ & $(0.000)$ & $(0.588)$ & $(0.174)$ \\
\hline Observations & 72 & 72 & 72 & 72 & 72 & 72 \\
\hline
\end{tabular}

p-values in parentheses

a for discrete change of dummy variable from 0 to 1

" $p<0.10, \cdots p<0.05, \cdots * p<0.01$

Note that legal origin dummies are based on the Klerman classification.

The dependent variables are advanced notice periods after nine months, four years, and 20 years of service respectively. 
Table 4.9: Ordered Probit Regressions I

\begin{tabular}{|c|c|c|c|c|c|c|}
\hline & \multicolumn{3}{|c|}{$1990-1995$} & \multicolumn{3}{|c|}{$2000-2005$} \\
\hline & nine months & four years & 20 years & nine months & four years & 20 years \\
\hline \multicolumn{7}{|l|}{ Variables } \\
\hline \multirow[t]{2}{*}{ (log) real GDP per capita } & -1.461 & -1.222 & $-2.446^{*}$ & -2.126 & -1.967 & -2.164 \\
\hline & $(0.255)$ & $(0.366)$ & $(0.058)$ & $(0.239)$ & $(0.317)$ & $(0.246)$ \\
\hline \multirow[t]{2}{*}{$(\log )$ real GDP per capita squared } & 0.074 & 0.074 & $0.159^{* * *}$ & 0.118 & 0.112 & 0.140 \\
\hline & $(0.334)$ & $(0.355)$ & $(0.042)$ & $(0.245)$ & $(0.306)$ & $(0.190)$ \\
\hline \multirow[t]{2}{*}{ Agriculture share of GDP } & -0.029 & -0.012 & -0.019 & -0.021 & -0.015 & -0.013 \\
\hline & $(0.171)$ & $(0.594)$ & $(0.430)$ & $(0.551)$ & $(0.711)$ & $(0.770)$ \\
\hline \multirow[t]{2}{*}{ Common Law Legal Origin } & 0.124 & -0.582 & 0.461 & -0.081 & -0.941 & 0.311 \\
\hline & $(0.861)$ & $(0.418)$ & $(0.584)$ & $(0.889)$ & $(0.118)$ & $(0.670)$ \\
\hline \multirow[t]{2}{*}{ Socialist Legal Origin } & 0.693 & 0.221 & -0.459 & $3.088^{* * * *}$ & 1.458 & $2.757^{* * *}$ \\
\hline & $(0.431)$ & $(0.737)$ & $(0.715)$ & $(0.007)$ & $(0.148)$ & $(0.004)$ \\
\hline \multirow[t]{2}{*}{ Scandinavian/German Legal Origin } & $1.718^{*}$ & -0.830 & 2.010 & $1.191^{*}$ & -1.387 & 1.525 \\
\hline & $(0.087)$ & $(0.370)$ & $(0.265)$ & $(0.062)$ & $(0.138)$ & $(0.306)$ \\
\hline \multirow[t]{2}{*}{ Trade Share $(t-1)$} & 0.012 & 0.001 & $0.024^{*}$ & $0.015^{* *}$ & 0.003 & $0.016^{*}$ \\
\hline & $(0.272)$ & $(0.923)$ & $(0.064)$ & $(0.009)$ & $(0.642)$ & $(0.075)$ \\
\hline \multirow[t]{2}{*}{ Trade Share $(t-1) \times$ Common Law } & -0.005 & 0.012 & -0.010 & -0.006 & $0.012^{*}$ & -0.006 \\
\hline & $(0.703)$ & $(0.291)$ & $(0.490)$ & $(0.348)$ & $(0.081)$ & $(0.502)$ \\
\hline \multirow[t]{2}{*}{ Trade Share $(t-1) \times$ Socialist } & -0.007 & -0.007 & -0.001 & $-0.030^{* *}$ & -0.011 & $-0.034^{* *}$ \\
\hline & $(0.696)$ & $(0.584)$ & $(0.974)$ & $(0.036)$ & $(0.337)$ & $(0.028)$ \\
\hline \multirow[t]{2}{*}{ Trade Share $(t-1) \times$ Scandinavian/German } & -0.010 & 0.022 & -0.022 & -0.010 & $0.028^{*}$ & -0.011 \\
\hline & $(0.504)$ & $(0.152)$ & $(0.421)$ & $(0.238)$ & $(0.065)$ & $(0.584)$ \\
\hline$\nu_{1}$ & -7.486 & -6.116 & -8.801 & -9.710 & -9.628 & -8.069 \\
\hline $1 / 2$ & -6.536 & -4.451 & -6.291 & -8.671 & -7.794 & -5.193 \\
\hline$\nu_{3}$ & -5.116 & -3.523 & -4.784 & -7.090 & -6.570 & -4.190 \\
\hline$\nu_{1} / \nu_{2}$ & 1.15 & 1.37 & 1.40 & 1.12 & 1.24 & 1.55 \\
\hline$\nu_{2} / \nu_{3}$ & 1.28 & 1.26 & 1.32 & 1.22 & 1.19 & 1.24 \\
\hline$\nu_{1} / \nu_{3}$ & 1.46 & 1.74 & 1.84 & 1.37 & 1.47 & 1.93 \\
\hline$N$ & 72 & 72 & 72 & 72 & 72 & 72 \\
\hline Log likelihood & -86.109 & -79.176 & -52.956 & -80.558 & -73.271 & -47.604 \\
\hline Pseudo- $R^{2}$ & 0.068 & 0.037 & 0.206 & 0.103 & 0.070 & 0.154 \\
\hline$\chi^{2}$ & 20.352 & 8.402 & 27.126 & 23.484 & 19.396 & 25.027 \\
\hline
\end{tabular}

Note that legal origin dummies are based on the La Porta classification.

The dependent variables are advanced notice periods after nine months, four years, and 20 years of service respectively. 
Table 4.10: Ordered Probit Regressions II

\begin{tabular}{|c|c|c|c|c|c|c|}
\hline & \multicolumn{3}{|c|}{$1990-1995$} & \multicolumn{3}{|c|}{$2000-2005$} \\
\hline & nine months & four years & 20 years & nine months & four years & 20 years \\
\hline \multicolumn{7}{|l|}{ Variables } \\
\hline \multirow[t]{2}{*}{$(\log )$ real GDP per capita } & -1.479 & -1.504 & $-2.537^{*}$ & -1.015 & -1.163 & -1.784 \\
\hline & $(0.250)$ & $(0.274)$ & $(0.064)$ & $(0.546)$ & $(0.523)$ & $(0.326)$ \\
\hline \multirow[t]{2}{*}{ (log) real GDP per capita squared } & 0.077 & 0.095 & $0.166^{* *}$ & 0.052 & 0.069 & 0.128 \\
\hline & $(0.306)$ & $(0.238)$ & $(0.039)$ & $(0.566)$ & $(0.489)$ & $(0.209)$ \\
\hline \multirow[t]{2}{*}{ Agriculture share of GDP } & -0.028 & -0.012 & -0.028 & -0.010 & 0.005 & 0.006 \\
\hline & $(0.217)$ & $(0.617)$ & $(0.255)$ & $(0.822)$ & $(0.904)$ & $(0.895)$ \\
\hline \multirow[t]{2}{*}{ Common Law Legal Origin } & 0.930 & 0.034 & $2.208^{* * *}$ & 0.583 & -0.381 & 0.826 \\
\hline & $(0.133)$ & $(0.957)$ & $(0.004)$ & $(0.304)$ & $(0.498)$ & $(0.284)$ \\
\hline \multirow[t]{2}{*}{ Mixed Legal Origin } & $4.531^{* * *}$ & $5.942^{*}$ & $4.428^{* * *}$ & -1.287 & 0.933 & $1.839^{* * *}$ \\
\hline & $(0.000)$ & $(0.066)$ & $(0.004)$ & $(0.246)$ & $(0.467)$ & $(0.002)$ \\
\hline \multirow[t]{2}{*}{ Scandinavian/Other Legal Origin } & $2.655^{* * *}$ & 0.438 & $3.523^{* *}$ & $2.485^{* * *}$ & 0.553 & $1.668^{* *}$ \\
\hline & $(0.003)$ & $(0.626)$ & $(0.017)$ & $(0.000)$ & $(0.179)$ & $(0.025)$ \\
\hline \multirow[t]{2}{*}{ Trade Share $(t-1)$} & $0.026^{* *}$ & 0.011 & $0.043^{\cdots *}$ & $0.019^{* * *}$ & $0.009^{*}$ & $0.016^{*}$ \\
\hline & $(0,021)$ & $(0.104)$ & $(0.000)$ & $(0.002)$ & $(0.055)$ & $(0.058)$ \\
\hline \multirow[t]{2}{*}{ Trade Share $(t-1) \times$ Common Law } & $-0.022^{*}$ & -0.003 & $-0.040^{* *}$ & $-0.016^{* *}$ & 0.000 & -0.013 \\
\hline & $(0.082)$ & $(0.808)$ & $(0.001)$ & $(0.034)$ & $(0.976)$ & $(0.157)$ \\
\hline \multirow[t]{2}{*}{ Trade Share $(t-1) \times$ Mixed } & $-0.085^{* * *}$ & $-0.099^{*}$ & $-0.082^{* * *}$ & 0.010 & -0.009 & $-0.014^{*}$ \\
\hline & $(0.002)$ & $(0.073)$ & $(0.000)$ & $(0.394)$ & $(0.505)$ & $(0.089)$ \\
\hline \multirow[t]{2}{*}{ Trade Share $(t-1) \times$ Scandinavian/Other } & $-0.035^{* *}$ & -0.009 & $-0.052^{* *}$ & $-0.028^{* * *}$ & -0.004 & $-0.019^{*}$ \\
\hline & $(0.021)$ & $(0.525)$ & $(0.018)$ & $(0.001)$ & $(0.516)$ & $(0.096)$ \\
\hline$\nu_{1}$ & -6.945 & -6.589 & -8.318 & -4.873 & -5.477 & -5.559 \\
\hline $1 / 2$ & -5.913 & -4.861 & -5.543 & -3.847 & -3.699 & -2.698 \\
\hline$\nu_{3}$ & -4.458 & -3.921 & -3.463 & -2.284 & -2.534 & -1.695 \\
\hline$\nu_{1} / \nu_{2}$ & 1.18 & 1.36 & 1.50 & 1.27 & 1.48 & 2.06 \\
\hline$\nu_{2} / \nu_{3}$ & 1.33 & 1.24 & 1.60 & 1.68 & 1.46 & 1.59 \\
\hline$\nu_{1} / \nu_{3}$ & 1.56 & 1.68 & 2.40 & 2.13 & 2.16 & 3.28 \\
\hline$N$ & 72 & 72 & 72 & 72 & 72 & 72 \\
\hline Log likelihood & -86.109 & -79.176 & -52.956 & -80.558 & -73.271 & -47.604 \\
\hline Pseudo- $\mathrm{R}^{2}$ & 0.068 & 0.037 & 0.206 & 0.103 & 0.070 & 0.154 \\
\hline$\chi^{2}$ & 20.352 & 8.402 & 27.126 & 23.484 & 19.396 & 25.027 \\
\hline
\end{tabular}

Note that legal origin dunmies are based on the Klerman classification.

The dependent variables are advanced notice periods after nine months, four years, and 20 years of service respectively. 
Table 4.11: Predicted Probabilities by Legal Origin I

\begin{tabular}{|c|c|c|c|c|c|c|c|c|}
\hline & \multicolumn{4}{|c|}{1995} & \multicolumn{4}{|c|}{2005} \\
\hline & $\begin{array}{c}\text { French } \\
\text { Civil Law }\end{array}$ & $\begin{array}{c}\text { Common } \\
\text { Law }\end{array}$ & $\begin{array}{c}\text { Socialist } \\
\text { Code }\end{array}$ & $\begin{array}{c}\text { Scandinavian/ } \\
\text { German Law }\end{array}$ & $\begin{array}{c}\text { French } \\
\text { Civil Law }\end{array}$ & $\begin{array}{c}\text { Common } \\
\text { Law }\end{array}$ & $\begin{array}{c}\text { Socialist } \\
\text { Code }\end{array}$ & $\begin{array}{r}\text { Scandinavian/ } \\
\text { German Law }\end{array}$ \\
\hline \multicolumn{9}{|c|}{ Notice Period Scores, nine months } \\
\hline $\operatorname{Pr}(L=0 \mid z)$ & 0.17 & 0.16 & 0.05 & 0.01 & 0.10 & 0.13 & 0.00 & 0.01 \\
\hline $\operatorname{Pr}(L=1 \mid z)$ & 0.33 & 0.32 & 0.20 & 0.05 & 0.30 & 0.34 & 0.00 & 0.08 \\
\hline $\operatorname{Pr}(L=2 \mid z)$ & 0.42 & 0.43 & 0.52 & 0.37 & 0.51 & 0.46 & 0.04 & 0.50 \\
\hline $\operatorname{Pr}(L=3 \mid z)$ & 0.08 & 0.09 & 0.23 & 0.58 & 0.09 & 0.07 & 0.96 & 0.42 \\
\hline \multicolumn{9}{|c|}{ Notice Period Scores, four years } \\
\hline $\operatorname{Pr}(y=0 \mid x)$ & 0.13 & 0.25 & 0.09 & 0.33 & 0.09 & 0.28 & 0.00 & 0.43 \\
\hline $\operatorname{Pr}(y=1 \mid x)$ & 0.58 & 0.59 & 0.54 & 0.56 & 0.60 & 0.62 & 0.17 & 0.52 \\
\hline $\operatorname{Pr}(y=2 \mid x)$ & 0.22 & 0.13 & 0.26 & 0.09 & 0.27 & 0.10 & 0.44 & 0.05 \\
\hline $\operatorname{Pr}(y=3 \mid x)$ & 0.07 & 0.03 & 0.10 & 0.02 & 0.04 & 0.01 & 0.39 & 0.00 \\
\hline \multicolumn{9}{|c|}{ Notice Period Scores, 20 years } \\
\hline $\operatorname{Pr}(y=0 \mid x)$ & 0.24 & 0.15 & 0.40 & 0.01 & 0.19 & 0.13 & 0.00 & 0.01 \\
\hline $\operatorname{Pr}(y=1 \mid x)$ & 0.73 & 0.78 & 0.59 & 0.47 & 0.79 & 0.83 & 0.23 & 0.70 \\
\hline $\operatorname{Pr}(y=2 \mid x)$ & 0.04 & 0.07 & 0.01 & 0.45 & 0.02 & 0.04 & 0.37 & 0.23 \\
\hline $\operatorname{Pr}(y=3 \mid x)$ & 0.00 & 0.00 & 0.00 & 0.07 & 0.00 & 0.00 & 0.40 & 0.06 \\
\hline
\end{tabular}

Note: Legal origins are the La Porta classification. 
Table 4.12: Predicted Probabilities by Legal Origin II

\begin{tabular}{|c|c|c|c|c|c|c|c|c|}
\hline & \multicolumn{4}{|c|}{1995} & \multicolumn{4}{|c|}{2005} \\
\hline & $\begin{array}{c}\text { French } \\
\text { Civil Law }\end{array}$ & $\begin{array}{c}\text { Common } \\
\text { Law }\end{array}$ & $\begin{array}{l}\text { Mixed } \\
\text { Origin }\end{array}$ & $\begin{array}{l}\text { Scandinavian/ } \\
\text { German Law }\end{array}$ & $\begin{array}{c}\text { French } \\
\text { Civil Law }\end{array}$ & $\begin{array}{c}\text { Common } \\
\text { Law }\end{array}$ & $\begin{array}{l}\text { Mixed } \\
\text { Origin }\end{array}$ & $\begin{array}{r}\text { Scandinavian/ } \\
\text { German Law }\end{array}$ \\
\hline \multicolumn{9}{|c|}{ Notice Period Scores, nine months } \\
\hline $\operatorname{Pr}(y=0 \mid x)$ & 0.13 & 0.03 & 0.00 & 0.00 & 0.10 & 0.04 & 0.49 & 0.00 \\
\hline $\operatorname{Pr}(y=1 \mid x)$ & 0.33 & 0.17 & 0.00 & 0.01 & 0.30 & 0.20 & 0.35 & 0.01 \\
\hline $\operatorname{Pr}(y=2 \mid x)$ & 0.45 & 0.53 & 0.00 & 0.17 & 0.51 & 0.56 & 0.15 & 0.19 \\
\hline $\operatorname{Pr}(y=3 \mid x)$ & 0.09 & 0.27 & 1.00 & 0.82 & 0.10 & 0.19 & 0.01 & 0.80 \\
\hline \multicolumn{9}{|c|}{ Notice Period Scores, four years } \\
\hline $\operatorname{Pr}(y=0 \mid x)$ & 0.11 & 0.11 & 0.00 & 0.06 & 0.09 & 0.16 & 0.01 & 0.03 \\
\hline $\operatorname{Pr}(y=1 \mid x)$ & 0.58 & 0.58 & 0.00 & 0.51 & 0.57 & 0.62 & 0.29 & 0.44 \\
\hline $\operatorname{Pr}(y=2 \mid x)$ & 0.23 & 0.23 & 0.00 & 0.30 & 0.28 & 0.19 & 0.44 & 0.39 \\
\hline $\operatorname{Pr}(y=3 \mid x)$ & 0.07 & 0.07 & 1.00 & 0.13 & 0.06 & 0.03 & 0.26 & 0.14 \\
\hline \multicolumn{9}{|c|}{ Notice Period Scores, 20 years } \\
\hline $\operatorname{Pr}(y=0 \mid x)$ & 0.21 & 0.00 & 0.00 & 0.00 & 0.19 & 0.06 & 0.00 & 0.01 \\
\hline $\operatorname{Pr}(y=1 \mid x)$ & 0.76 & 0.53 & 0.01 & 0.17 & 0.79 & 0.84 & 0.56 & 0.70 \\
\hline $\operatorname{Pr}(y=2 \mid x)$ & 0.02 & 0.45 & 0.38 & 0.70 & 0.02 & 0.09 & 0.31 & 0.23 \\
\hline $\operatorname{Pr}(y=3 \mid x)$ & 0.00 & 0.02 & 0.62 & 0.13 & 0.00 & 0.01 & 0.12 & 0.06 \\
\hline
\end{tabular}

Note: Legal origins are the Klerman classification). 
Figure 4.1: Predicted Probabilities by Trade Share, Notice Periods After Nine Months of Service, 2005

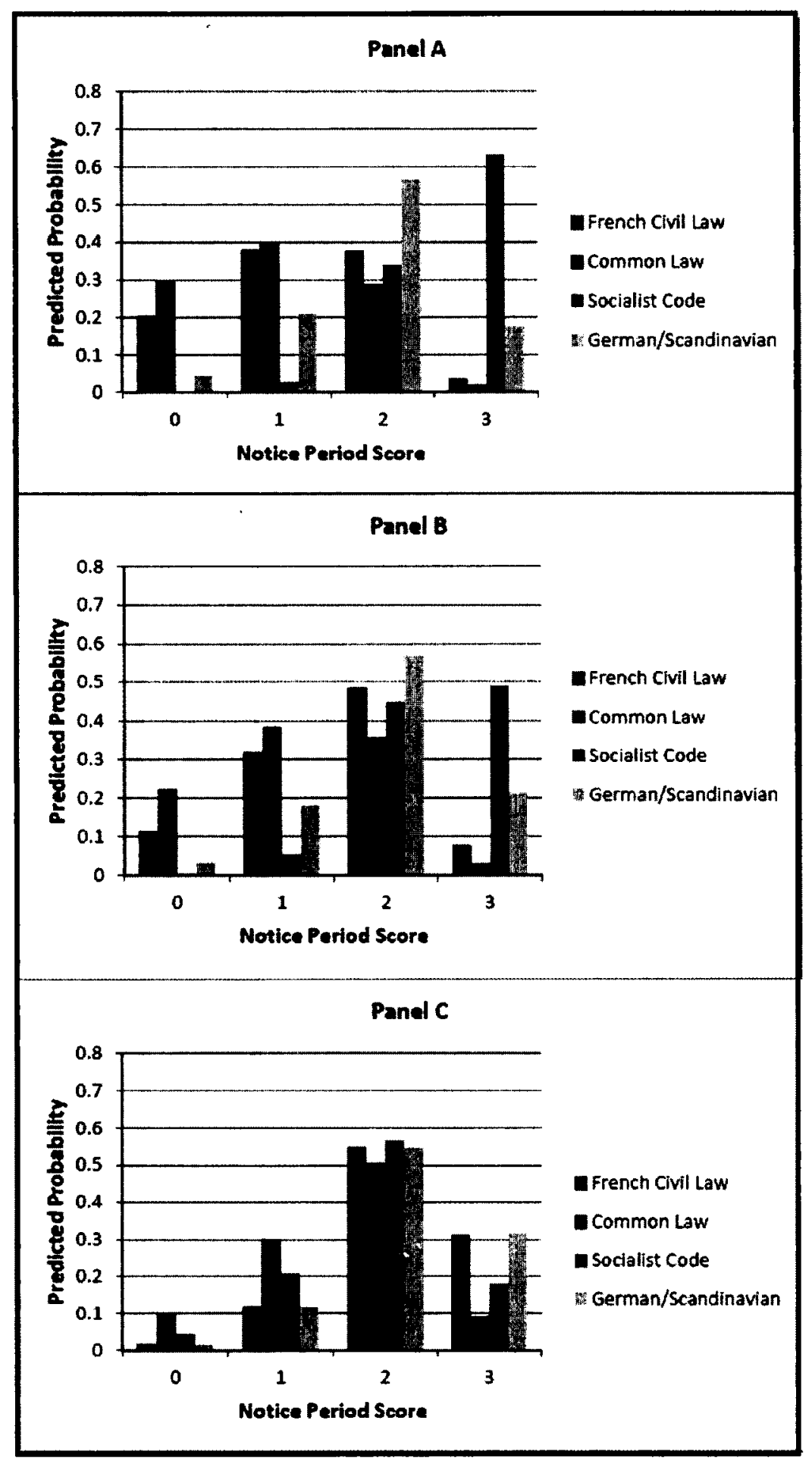

Note: Panels A, B, and C are calculated using trade shares at the tenth, 50th, and 95th percentiles respectively. All other variables (other than legal origin dummies) are held at the overall means. Legal origins are the La Porta classification. 
Figure 4.2: Predicted Probabilities by Trade Share, Notice Periods After Four Years of Service, 2005

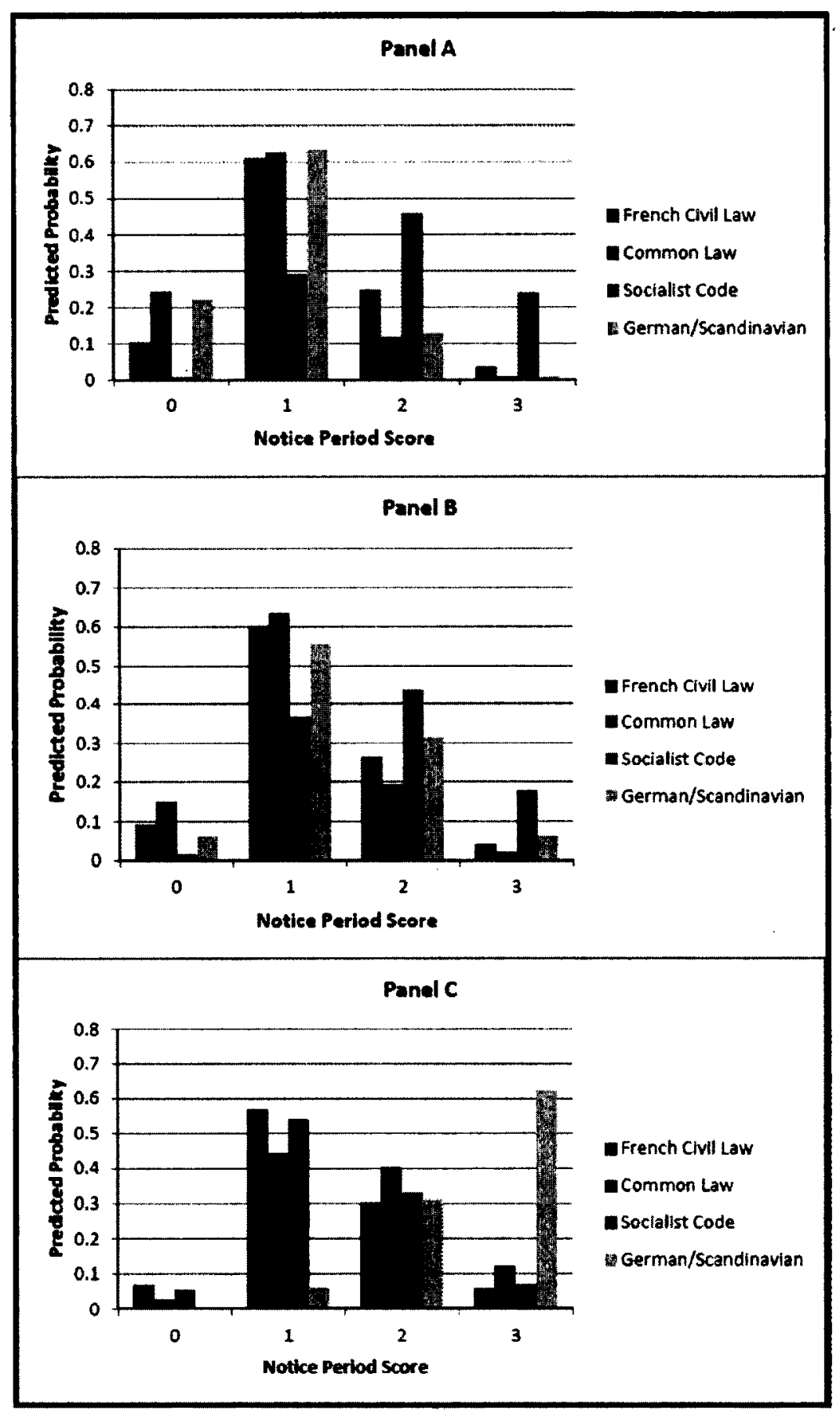

Note: Panels A, B, and C are calculated using trade shares at the tenth, 50th, and 95th percentiles respectively. All other variables (other than legal origin dummies) are held at the overall means. Legal origins are the La Porta classification. 
Figure 4.3: Predicted Probabilities by Trade Share, Notice Periods After 20 Years of Service, 2005

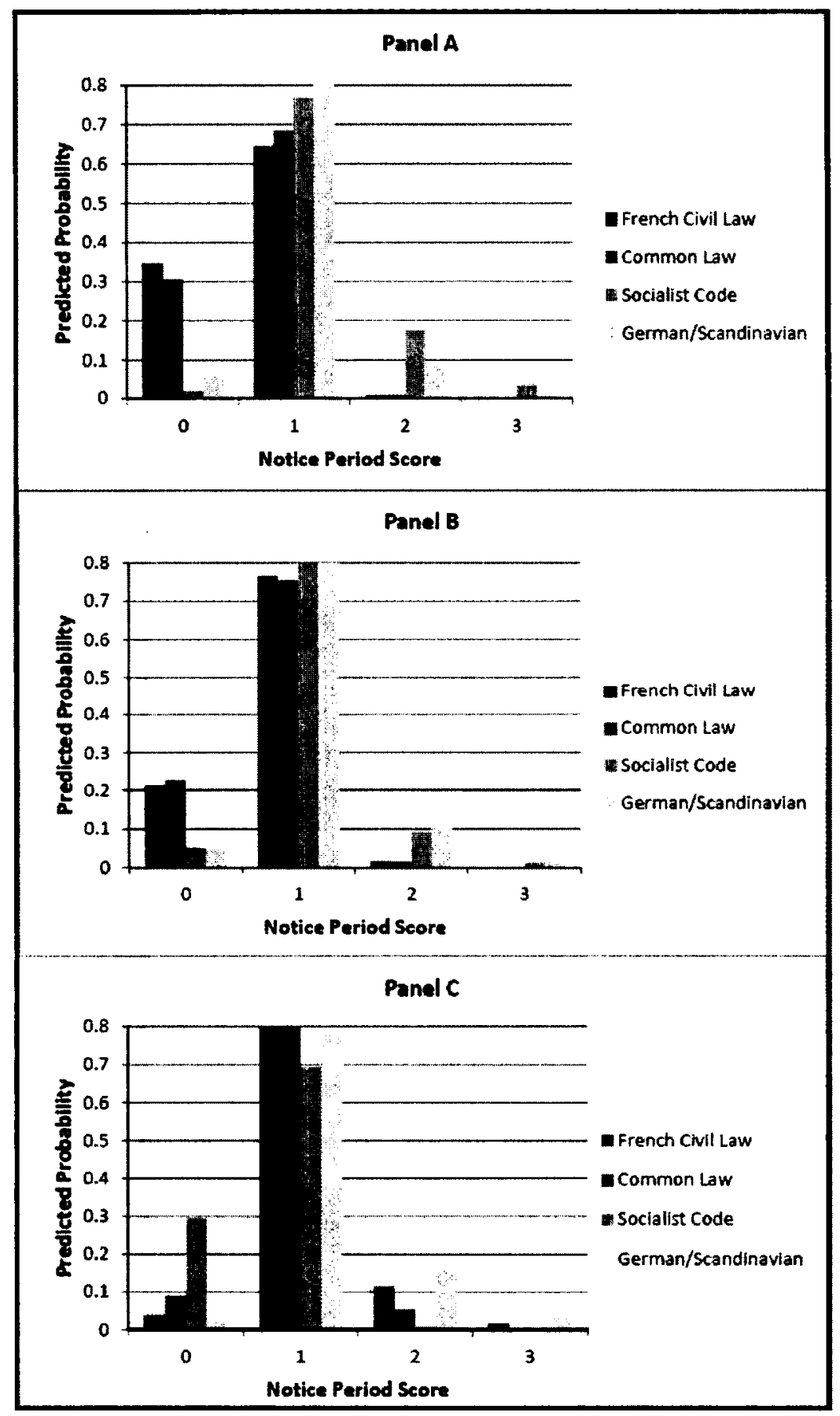

Note: Panels A, B, and C are calculated using trade shares at the tenth, 50th, and 95th percentiles respectively. All other variables (other than legal origin dummies) are held at the overall means. Legal origins are the La Porta classification. 
Figure 4.4: Predicted Probabilities by Trade Share, Notice Periods After Nine Months of Service, 2005

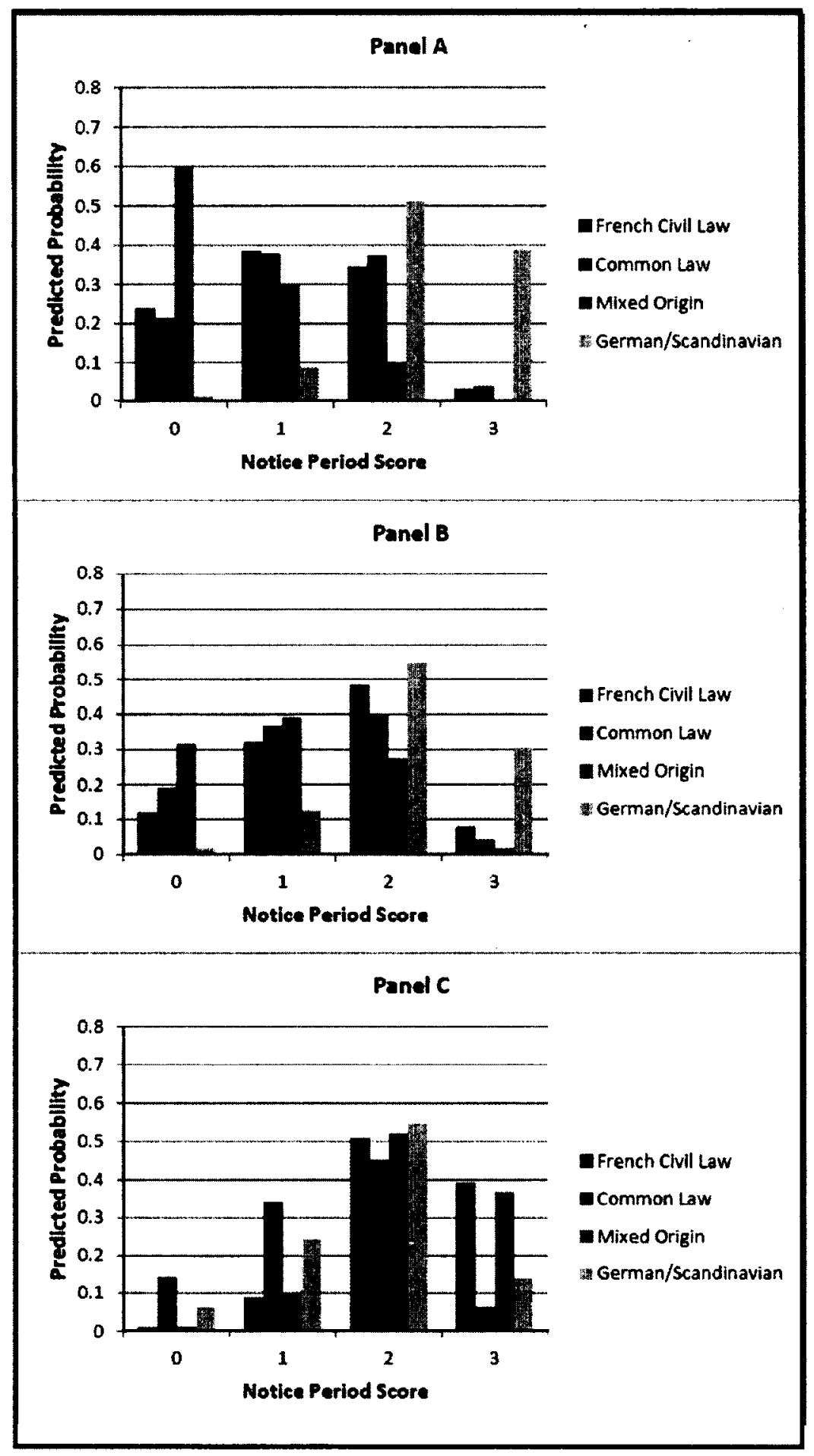

Note: Panels A, B, and C are calculated using trade shares at the tenth, 50th, and 95th percentiles respectively. All other variables (other than legal origin dummies) are held at the overall means. Legal origins are the Klerman classification. 
Figure 4.5: Predicted Probabilities by Trade Share, Notice Periods After Four Years of Service, 2005

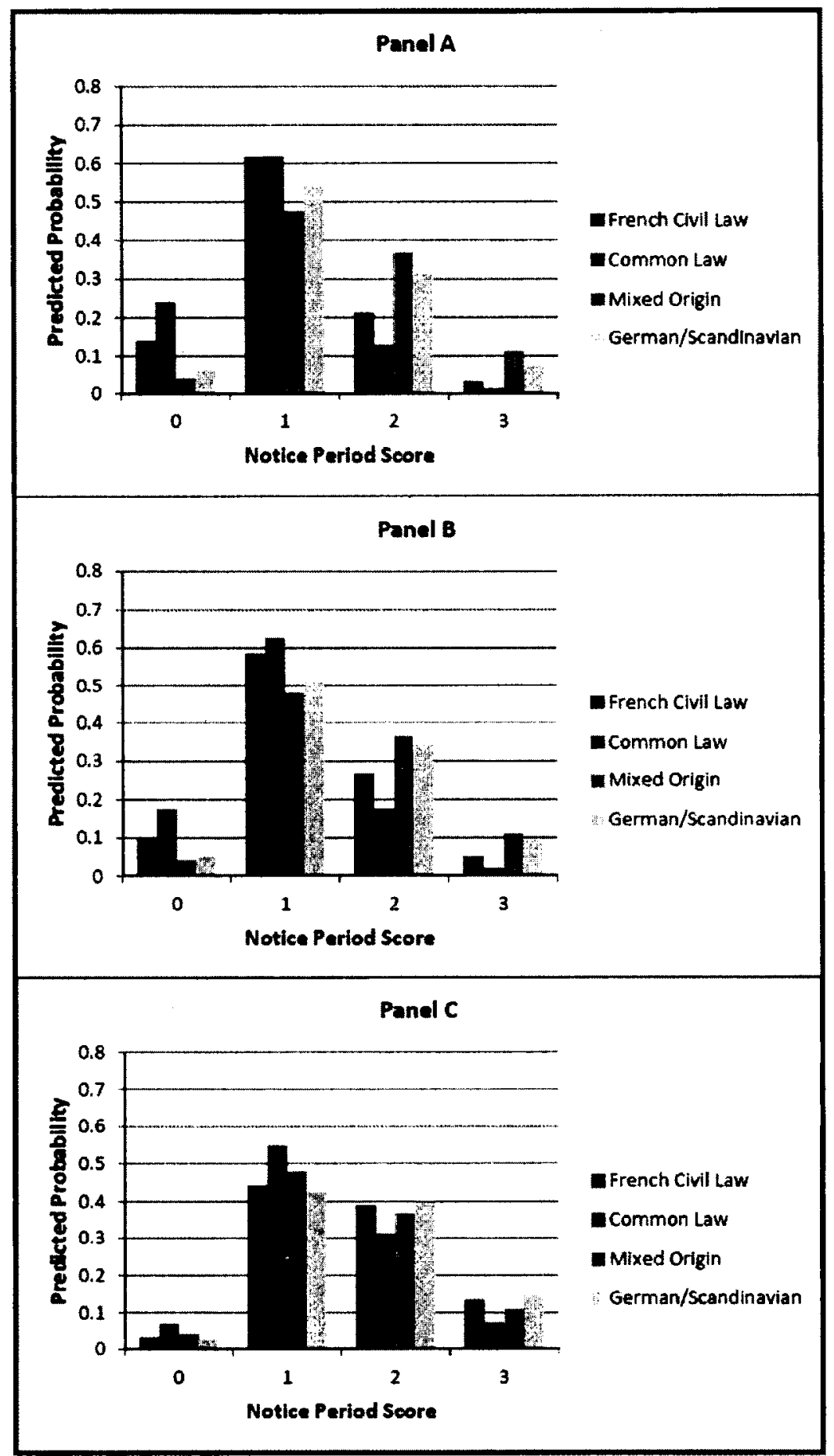

Note: Panels A, B, and C are calculated using trade shares at the tenth, 50th, and 95th percentiles respectively. All other variables (other than legal origin dummies) are held at the overall means. Legal origins are the Klerman classification. 
Figure 4.6: Predicted Probabilities by Trade Share, Notice Periods After 20 Years of Service, 2005

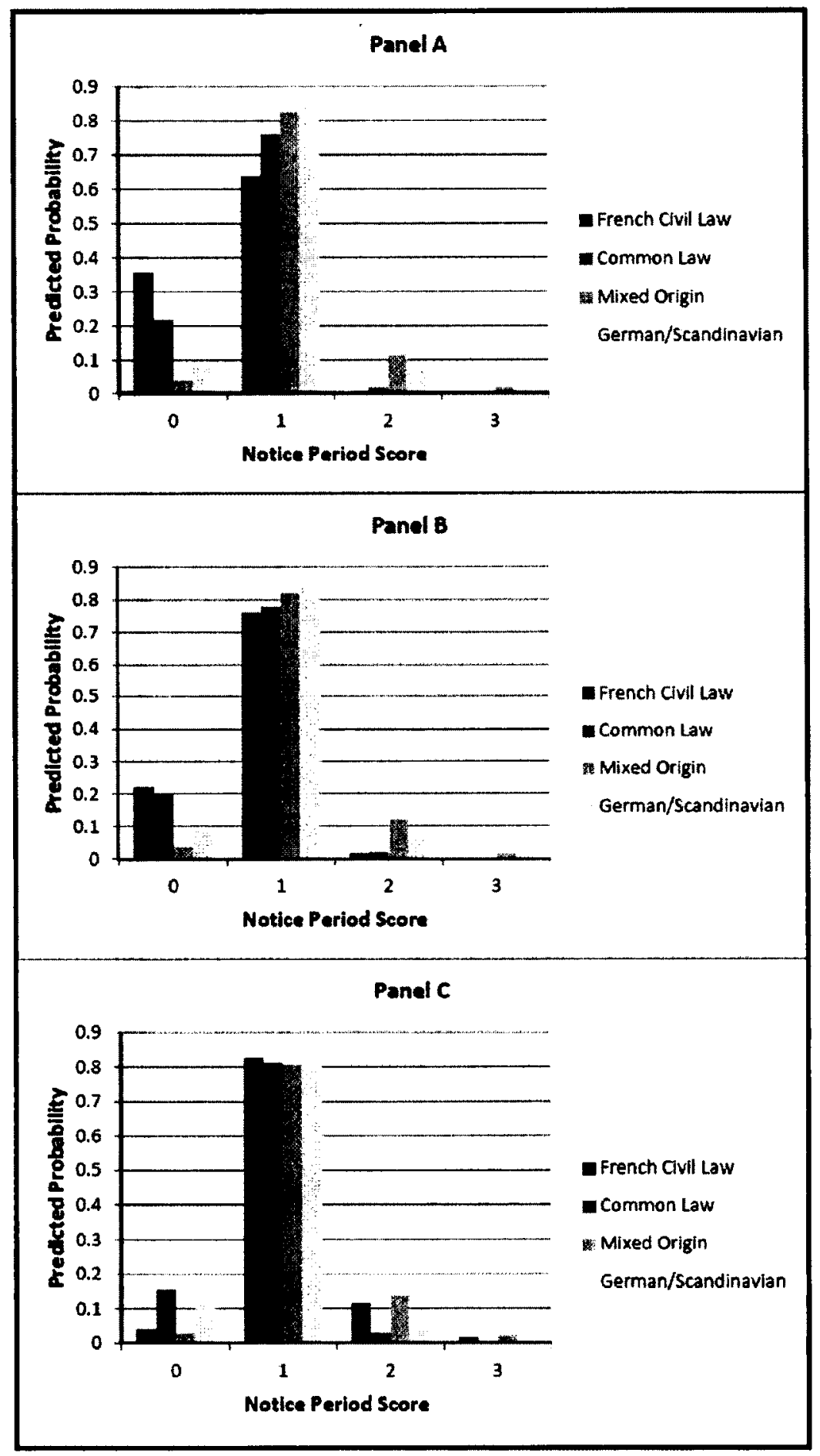

Note: Panels A, B, and C are calculated using trade shares at the tenth, 50th, and 95th percentiles respectively. All other variables (other than legal origin dummies) are held at the overall means. Legal origins are the Klerman classification. 
Figure 4.7: Predicted Probabilities by Trade Share, Notice Periods After nine months of Service, $L=2$

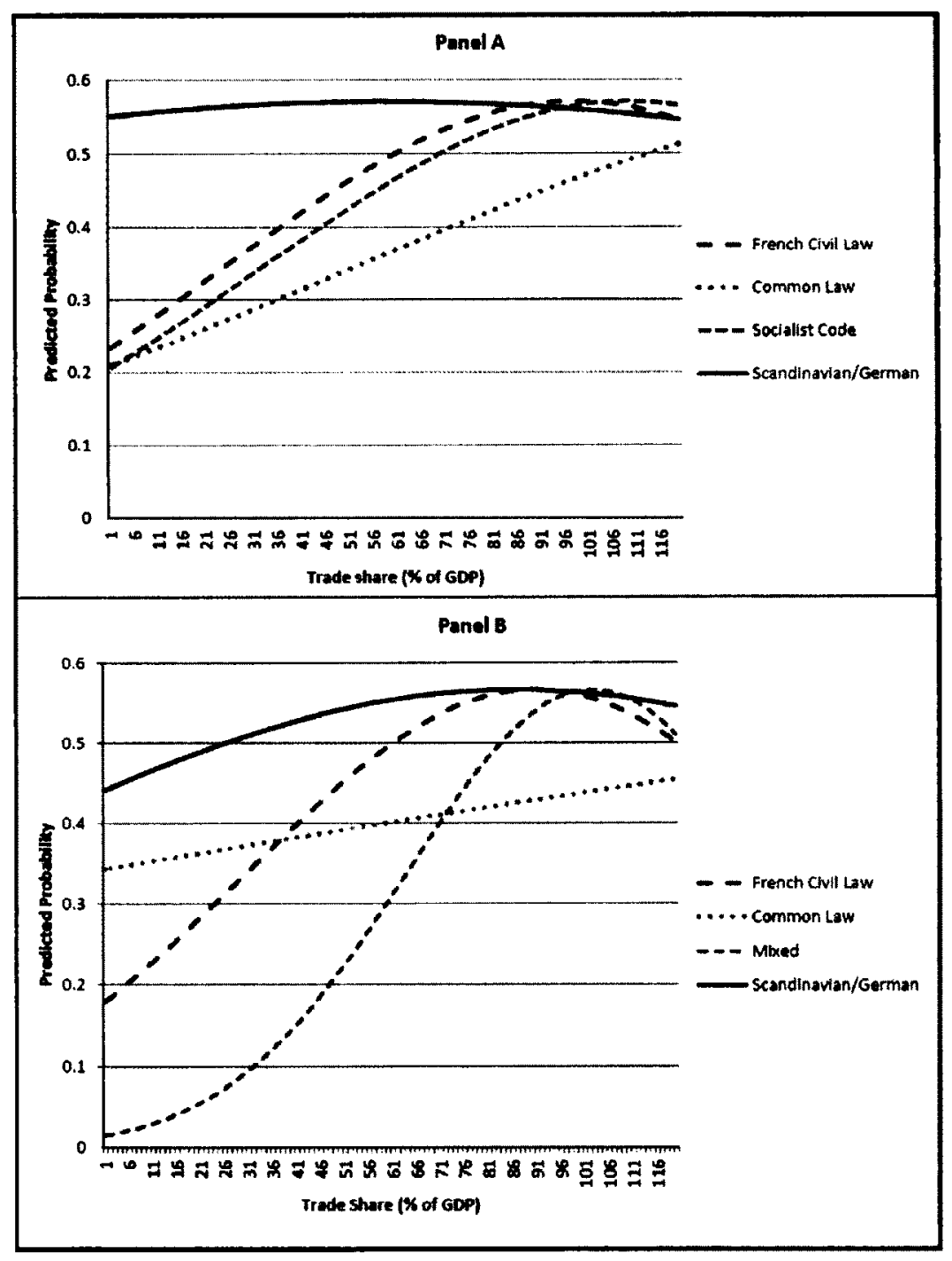

Note: Panel A uses the La Porta legal origin classification and Panel B uses the Klerman classification. 
Figure 4.8: Predicted Probabilities by Trade Share, Notice Periods After 4 years of Service, $L=1$ and $L=2$

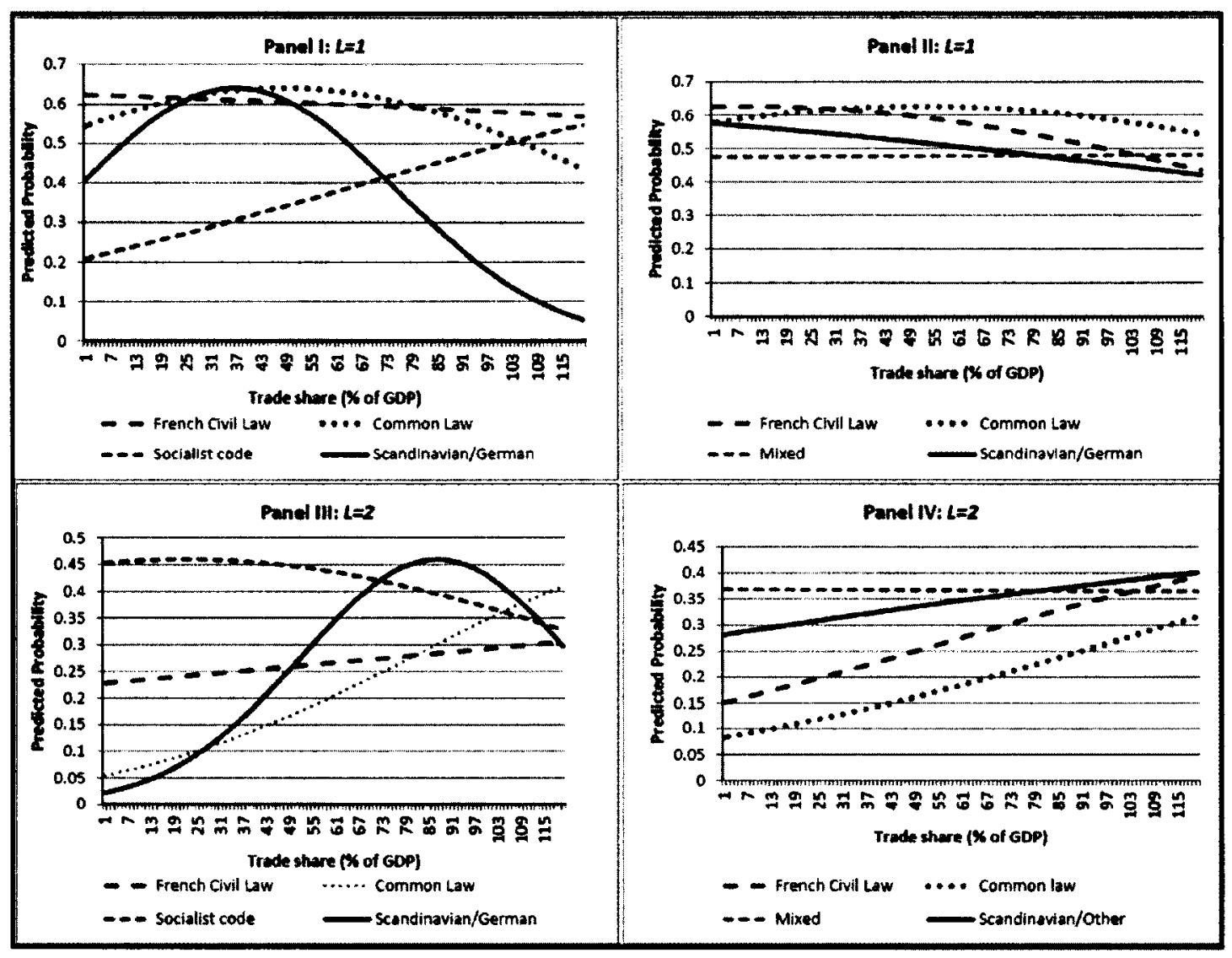

Note: Panels I and III and use the La Porta legal origin classification and Panel II and IV use the Klerman classification. 
Figure 4.9: Predicted Probabilities by Trade Share, Notice Periods After 20 of Service, $L=1$

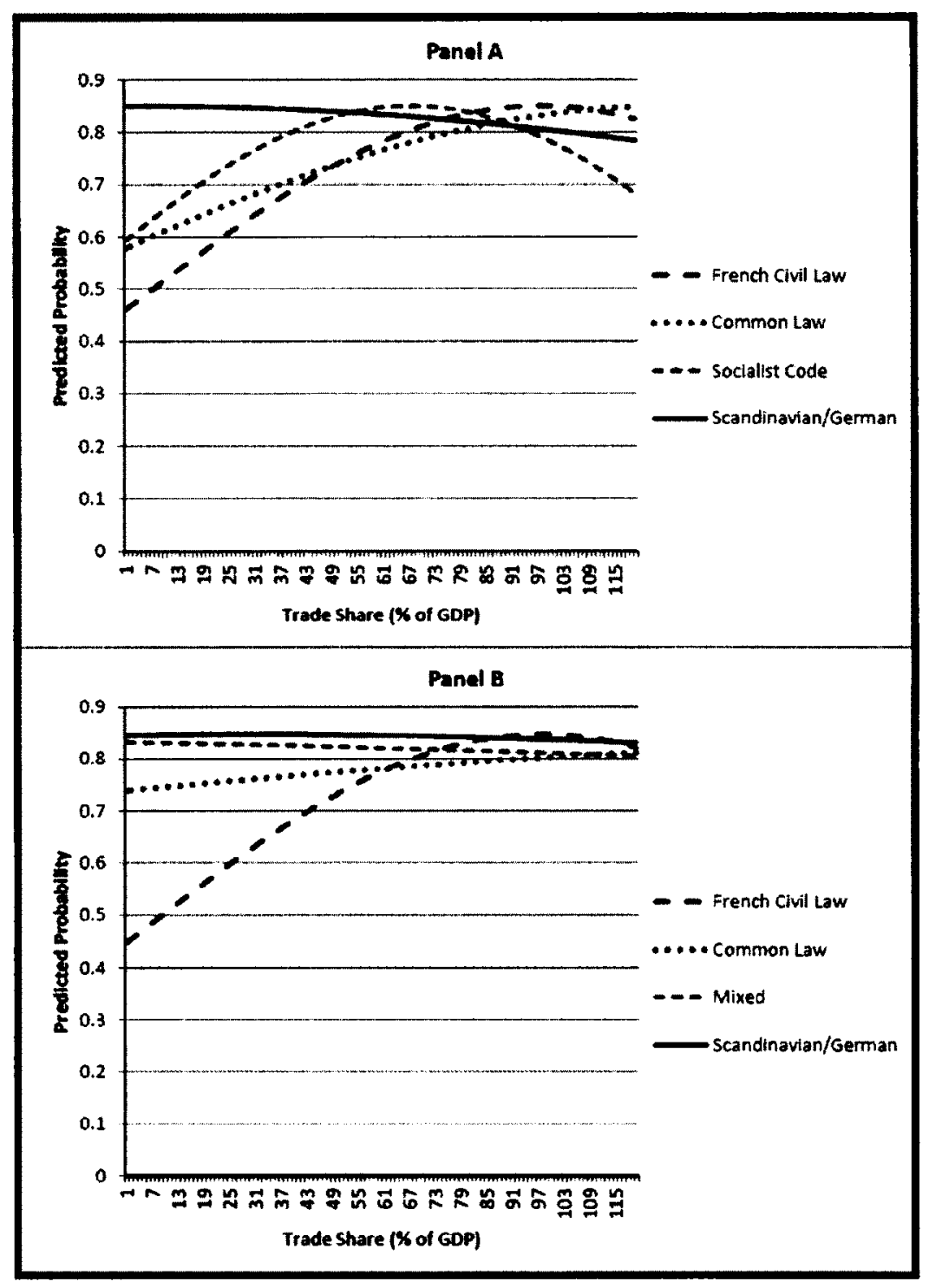

Note: Panels A uses the La Porta legal origin classification and Panel B uses the Klerman classification. 


\section{Chapter 5}

\section{Conclusion}

In this thesis, I have focused on two main topics surrounding the economic impacts of globally integrated markets - exchange rate volatility and export performance and trade and labour standards. Chapter 2 examined the impact of exchange rate volatility for a sample of developing and transition economies. To summarize results, System GMM appears to be the superior approach in analyzing this question, as it takes into account the dynamic nature of the model, the potential endogeneity of volatility in the exports-volatility relationship, the possibility of country-specific effects, and the relatively persistent behaviour of exports. This method has been little used in the literature to date. Results point to an overall negative impact of exchange rate volatility in exports, with the largest robust impact found for a new measure of volatility. Using this measure, a deterring impact on exports was estimated to be approximately 6 percent for a one standard deviation increase in volatility. A negative impact of the first measure of volatility (the standard deviation of the first differences of the REER) was also found, though this impact was not robust to the last specification of the System GMM model. However, when restricted to lower income countries, both measures had robust statistically significant negative impacts on exports. These results suggest that developing and emerging market economies wishing to promote exports may be able to do so by also supporting exchange rate stability with major currencies, particularly for poorer countries. 
Chapter 3 presented a theoretical model linking trade and and minimum wages, in an attempt to assess real-world concerns that trade may lead to a race-to-the-bottom in labour standards. Using an international duopoly model of strategic trade with monopsonistic factor markets, analysis shows that international rivalry in product markets does not necessarily lead to a RTB in labour standards. This result stems from the monopsonistic labour market, where welfare-maximizing governments actually have the incentive to increase wages in an attempt to increase employment and output of firms. This implies that, to the extent that race-to-the bottom in labour standards is a real problem, it is caused not by international rivalry in product markets, but by the failure of governments to maximize their domestic welfare. In a real-world context, weak institutions could result in such market failure. Though labour standard policies may exist in many developing countries, for example, it is possible that they are poorly or sporadically enforced.

Finally, Chapter 4 empirically examined the impact of trade openness on employment protection, but in a legal origins context. Two alternate approaches were used to measure labour standards, both based on advance notice periods employers are required to give employees upon dismissal. Accordingly, two different econometric models were used - a Tobit model on raw notice periods (measured in months) and a a four-choice ordered probit model on an ordinal ranking of the stringency of notice periods. This analysis was conducted on notice periods at three different levels of tenure and two alternate classifications of legal origin. The main findings from this analysis are summarized as follows. By affecting the regulatory framework and its flexibility, legal origins are most important when the pressures of international competitiveness are minimal. As trade openness increases and economies become much more globalized, these pressures become important and differences due to legal origin appear to wane in relative importance. In other words, although greater openness also likely increases domestic pressures to strengthen labour protection, these 
are, perhaps, not enough to counter the international competitive pressures that also arise from greater openness. Furthermore, at high levels of openness, countries show a tendency to move to a similar level of stringency of labour standards pertaining to notice periods. It would appear that very open countries work towards eliminating differences in labour standards. This argument suggests that there are incentives for a RTB, namely that if labour standards are set too high by one country, it is advantageous for others to set a slightly lower standard to gain a competitive edge, which in turn leads to a further reduction of standards by the first country, and so on. However, findings suggest that countries would not move to the bottom. 